\title{
(6)ederi $20(2010)$
}

\section{Table of contents}

\section{Articles}

The Pageant of History: Nostalgia, the Tudors, and the Community Play Michael Dobson

"I have written the things which I did hear, see, tasted and handled:" Selfhood and Voice in

Katherine Evans' and Sarah Cheevers' A Short Relation of TheirSufferings (1662)

Carmen Font Paz

Baubles on the Water: Sea Travel in Shakespeare's Time

Andrew Gurr

Macbeth and the Passions' "Proper Stuff"

Zenón Luis Martínez

The French Influence on Early Shakespeare Reception in Spain: Three Cases of

Unacknowledged Sources

Ángel-Luis Pujante

Ludwig Tieck's Herr Von Fuchs (1793) As the Perfect Embodiment of Romantic Irony Purificación Ribes Traver....

Notes

"The king has killed his heart:" The Death of Falstaff in Henry V

R. Scott Fraser

\section{Reviews}

Elliott, J.H. 2009. Spain, Europe and the Wider World, 1500-1800

(by Juan E. Tazón) 161

Jesús López-Peláez Casellas. 2009. "Honourable Murderers" El concepto del honor en Othello de Shakespeare y en los dramas de honor de Calderón

(by Luciano García García) 165

Glyn Redworth. 2008. The She-Apostle. The Extraordinary Life and Death of Luisa de Carvajal (by Felipe Fernandez-Armesto) .

Joseph P. Ward ed. 2008. Violence, Politics, and Gender in Early Modern England

(by Carme Font Paz) 177 


\title{
The Pageant of History: Nostalgia, the Tudors, and the Community Play
}

\author{
Michael Dobson \\ Birkbeck, University of London
}

\begin{abstract}
This paper considers the persistence of the Renaissance pageant in modern and post-modern culture, both as a recurrent metaphor for history in general and as a feature of stage, cinematic and communal representations of early modern history in particular. After examining the status of public processions in Renaissance London as conscious revivals of the Roman triumph, indebted at the same time to aspects of the medieval mystery plays, the essay examines the English historical pageants of the Edwardian and inter-war years as themselves revivals of both Renaissance pageantry and aspects of the Shakespearean history play. It looks in particular at their emphasis on the Tudor monarchs and on the ethnic origins of Englishness, identifying the fading of the pageant as a genre in the post-war years with the collapse of certain ideas about English exceptionalism and historical continuity.
\end{abstract}

KEYWORDS: Pageants, processions, Edwardian outdoor theatre, amateur historical drama, Tudor monarchy in popular culture.

In thinking about the early modern past in general, Anglophones still habitually use the phrase "the pageant of history," as if picturing the sequence of historical events as so many decorated floats in a passing procession. The project of this essay is to unpack this dead metaphor, to think through the pageant of history in terms of the history of pageants. It will examine the extent to which the "pageant of history" metaphor hasn't in fact been dead at all over the last century, but lived on for film-makers determined to make an emblematic spectacle of the Renaissance, and for their immediate precursors in amateur dramatics, who re-enacted the early modern 
period on the village greens of England. The essay will proceed in three stages: first, it will outline the pre-history of the modern pageant, by looking at its forebears and analogues in the Renaissance proper; then it will look at how and why Renaissance history and drama were so central to the great pageants of the early twentieth century; and then it will consider how pageantry, and the assumptions about the nature of history which it encodes, migrated into cinematic depictions of the sixteenth century. The pageant finally disappeared after the Second World War, I hope to show, because it had always encoded a set of beliefs about the nature of British history which by the 1950s, for all the "New Elizabethan" rhetoric of Coronation Year, could no longer be sustained.

\section{Pageants before Pageants}

During the first half of the twentieth century, although these events have attracted little scholarly attention to date, ${ }^{1}$ English cathedral cities, market towns and hamlets put on a large number of historical pageants, habitually preoccupied with what the English think of as the Tudor period. Before we automatically dismiss these attempts at re-enacting the Renaissance as merely embarrassing and inaccurate distortions of the past, amateurishly staged in the service of local self-aggrandisement, it's worth reflecting on the extent to which the Renaissance itself was just such an inaccurate and selfaggrandising re-enactment in the first place.

Attempts by Renaissance antiquarians to reconstruct ancient Roman victory processions, as in the works of Italian humanists such as Flavio Biondo (in the 1450s) and Onofrio Panvinio (in the 1550s), overlapped with massive exercises in re-enacting them. In 1443, for example, Alfonso of Aragon staged a lavishly-researched parade through Naples to mark his accession to the city-state's throne the previous year, and similar events staged by the Gonzaga dynasty in Mantua informed their commissioning of a celebrated series of pictures, Mantegna's much-copied Triumphs of Caesar, in the 1480s. These processions, however, were comprehensively outdone by the Emperor Charles V's triumphal entry into Rome itself in 1536, in celebration of his allegedly Scipio-like military successes in North

\footnotetext{
${ }^{1}$ For the main exceptions, see Wallis (2006) and Esty (2003).
} 
Africa. In preparation for this occasion, Pope Paul III, to the disgust of Rabelais, had large swathes of the city demolished so as to clear what he believed were the processional routes favoured by Charles' pagan predecessors (Beard 2007:53-55). By the beginning of the seventeenth century, this drive to re-enact the processions of antiquity had even reached England, for example in the form of the moralized triumphal arches designed for James VI and I's coronation entry into London by, among others, that useful classicist and stagemanager Ben Jonson. For Renaissance princes, it appeared, history was cyclical: now redeemed and enhanced by Christianity, the golden ages of antiquity might be had all over again.

Off the streets, meanwhile, neoclassical processions had by now been part of the essential rhetorical grammar of the Renaissance for three centuries, largely thanks to the pan-European influence of Francesco Petrarch. Petrarch's Trionfi (c.1356-74) had established an enduring pattern by which an allegorical poem might rehearse an argument through recounting an imaginary victory parade. In England, Elizabeth I drew some the iconography of her own postmenopausal "second reign" from the Triumph of Chastity, and Petrarch's influence pervades Edmund Spenser's The Faerie Queene (1590-1596). Canto xii of book III ("Of Chastity"), features "The Maske of Cupid," in which no fewer than twenty-six successive stanzas describe the sorrows and delusions of romantic love in the form of a seemingly endless parade of allegorical floats, each introduced with the words "Next after him went....", "With him went...", "Next him was...", "After all these there marcht...", and so on.

Spenser calls this a "masque" rather than a pageant, and it is important both to the development of the pageant as a dramatic form in England and to its continuing resonances as a metaphor since that in Elizabethan times the word itself still carried connotations that were more Christian than classical. In current British usage the term "pageant" now generally refers to a dramatic genre. ${ }^{2}$ But a "pageant" was originally a thing rather than an event,

\footnotetext{
${ }^{2}$ Incidentally, and this is something to be careful of if you are ever doing picture research about pageants on the internet, in current North American popular usage a pageant is generally a beauty contest, in which the processions and floats display not civic worthies dressed up in a collective evocation of local history but nubile women in bathing costumes, exhibited competitively as if at an agricultural show. Even more
} 
namely the platform -whether static or taking the form of a wheeled wagon- on which a scene would be enacted in a medieval mystery play. At most, the term might extend to denoting a single episode from Biblical history played on one such structure. This original sense of the word survived the Reformation's abolition of the mystery cycles, though the technology that had hitherto been used for enacting the entire history of the world from the Creation to the Last Judgement was reassigned to less ambitious uses. Pageantwagons continued to rumble annually through the streets of London, now engaged, not in representing the fall and redemption of man, but merely in celebrating the city guilds' election of a new Lord Mayor.

The increasing elaboration of the Lord Mayor's Day procession during the reigns of Elizabeth and James brought in the city's first generation of professional playwrights. In 1585, for instance, George Peele published the speeches he had composed for the personnel manning the main allegorical cart deployed that year as The device of the pageant borne before Woolstone Dixi Lord Mayor of the City of London. Peele, significantly, when not scripting this sort of civic street theatre for the Mayor or designing flattering court performances for Elizabeth, was a pioneer of the chronicle play, the author of Edward I. In the hands of his Jacobean successors as scriptwriters to the city fathers, even the London mayoral pageant explicitly became a vehicle for secular history. Anthony Munday, for example, composed The Triumphs of Re-United Britannia for the procession of 1605, and from this period onwards the phrase "The Triumphs of..." becomes the standard title for this event, promoting the Lord Mayor to the status of an honorary Roman general. This particular pageant naturalizes the classical tradition by depicting the legendary founder of Britain, Aeneas' apocryphal son Brute, who divides the realm between his sons Locrine, Camber and Albanact to produce England, Wales and Scotland -the point to which the show tends is that these are now being gloriously reunited under King James. In processions such as this one, the Italianate revival of elements of the classical triumph, memories of the mysteries, and aspects of the native chronicle play were already beginning to combine to produce

of a snare for the unwary researcher, there is apparently also something in Guyana called the Ms Renaissance Pageant. 
something like the historical pageant as the twentieth century would come to know it.

Meanwhile history was also being dramatized in the purposebuilt playhouses, not least by William Shakespeare, who was working on his own script about the division of ancient Britain between three siblings, King Lear, around about the time that Munday's parade was grinding by. Given the importance of Shakespeare's histories to the subsequent development of the pageant, it's worth pausing to consider how Shakespeare himself understood the relations between pageantry and history.

Shakespeare's uses of the word "pageant" sometimes look like ours, and his history plays have been imitated and excerpted so extensively in the kinds of show which we would now call pageants that it is sometimes hard to remember that he hadn't seen one himself. In fact the one show-within-a-show in the canon that is usually referred to as a pageant -the Pageant of the Nine Worthies in the last act of Love's Labour's Lost- isn't properly categorized as such in Shakespeare's text at all, but with the prodigality of vocabulary for which this play is famous it is only called for, before either its form or its subject-matter have been chosen, as "some delightful ostentation, or show, or pageant, or antic, or firework" (5.1.105-107). If he missed out on the modern pageant, though, as a boy Shakespeare may have been among one of the last ever audiences for the old-style religious pageants of the Coventry mystery cycle. Perhaps this is why for Shakespeare the word "pageant" is usually tinged with a thoroughly medieval and melancholy contemptus mundi. "This wide and universal theatre," Duke Senior remarks in As You Like It in what sounds like an explicit glance back to the mysteries, "Presents more woeful pageants than the scene / Wherein we play in" (2.7.137-139). ${ }^{3}$ The word "pageant" for Shakespeare, as

\footnotetext{
${ }^{3}$ It's true that in Shakespeare the term sometimes functions, like "mockery," simply as a negative expression for any kind of representation, as when the Turkish fleet's feigned attack on Rhodes is described as a "a pageant" to keep the Venetians "in false gaze" (Othello 1.3.19-20). In a similar pejorative sense, Patroclus in Troilus and Cressida is said to "pageant" the Grecian commanders for the amusement of Achilles (1.3.151), and later on Thersites, an even more scurrilous impersonator, performs his satirical "pageant of Ajax" for the same audience (3.3.262-3). Simultaneously mocking and rueful, Troilus and Cressida, incidentally, contains three out of Shakespeare's total of sixteen uses of the word "pageant": appropriately for a play in which the Trojan army, beneath the gaze of Cressida and Pandarus, is reduced to a long classical procession of
} 
here, sometimes suggests the glories of this world revealed as a delusive show -as in Prospero's "insubstantial pageant faded," which leaves "not a rack behind" (The Tempest 4.1.155), or the doomed Antony's recollection of metamorphosing clouds at sunset as "black vesper's pageants" (Antony and Cleopatra 4.15.8). Alternatively, it sometimes denotes a show that is all about exposing and even punishing worldly vanities as such. Margaret in Richard III, for example, sees Queen Elizabeth in her short-lived prosperity as "The flattering index of a direful pageant, / One heaved a-high to be hurled down below" (4.4.85-86), while the Abbot of Westminster, moved by the edifying spectacle of Richard II's deposition, sighs that "A woeful pageant have we here beheld" (4.1.311). It's a sign of how unwary the ambitious Duchess of Gloucester is about the treacherous insecurity of earthly pomp in Henry VI part 2 that she announces her desire to make herself queen with the words "I will not be slack / To play my part in Fortune's pageant" (2 Henry VI 1.2.66-67). Whether interrupted by the "moved" Prospero or terminated by an abrupt fall from grace, pageants in Shakespeare don't have happy endings: the most elaborately-staged procession in the canon, complete with "shows, / Pageants, and sights of honour" (All is True [Henry VIII] 4.1.10-11), is for the coronation of the ill-fated Anne Boleyn.

Like the mystery cycles, then, for Shakespeare pageants expose human history as essentially insignificant, however gaudily ornamented. They are the inadequate and fleeting representations of a struggle for prizes that can't be kept and aren't worth having anyway, akin to the "little scene" with which Death temporarily indulges monarchs in the great "For God's sake let us sit upon the ground..." monologue in Richard II (3.2.160). It used to be argued that Shakespeare had simply secularized the optimistic teleological sweep of the mystery cycles, offering the providential story of the Wars of the Roses and the coming of the Tudors as a specifically English counterpart to the providential story of the Fall and its ultimately fortunate consequences. ${ }^{4}$ This now seems questionable,

sexual talent (1.2.177-240), the other comes when Troilus, who has clearly read Petrarch and Spenser, refers to "all Cupid's pageant" (3.2.71-2).

${ }^{4}$ Whether or not his history plays really offer the Tudor dynasty as the political equivalent of eternal salvation now seems more questionable -they might just as well be read, surely, as dramatizing English royal government as a problem as much as a 
but what Shakespeare's histories undoubtedly do when considered as a single connected sequence -as the Folio prints them- is to respond to the mystery plays' provision of a kind of drama which takes Mankind as its subject across the whole of cosmic history by producing instead a kind which takes the English monarchy as its subject across just a couple of centuries of national history. As such they provide one important precedent for the new form of chronicle play which would stage Shakespeare's England in the twentieth century.

\section{Pageants: The Golden Age}

Some traditions of Renaissance processional were kept alive down the succeeding years by the Lord Mayor's Day parade and all those Hanoverian coronations, but the rediscovery of early modern pageantry per se begins in earnest in the Romantic period. Just as early modern humanists had participated in the Renaissance by researching classical parades, so late eighteenth-century antiquarians did their bit for Romanticism by discovering and publishing every detail they could of Renaissance pageantry, now newly-cherished as the expression of a richer and more colourful lost world. Between 1788 and 1805 , for instance, John Nichols, a worthy English heir to Panvinio, published a massive three-volume compilation of all the surviving records he could find of The Progresses and Public Processions of Queen Elizabeth. This publication served as a major resource both for the designers of historical spectacle in the theatre, such as J.R. Planché, and for the authors of historical novels, such as Sir Walter Scott, whose Kenilworth (1821) draws heavily on Nichols throughout (Dobson and Watson 2002:111-115,139-140). The desire not just to research but to re-enact these Renaissance events finally achieved full expression in 1905, in the first outdoor work of a single remarkable artist, Louis Napoleon Parker.

Every bit as commanding as his Christian names might suggest, Parker had already followed three careers before inventing the Edwardian historical pageant. He was a respected composer, who had been made a fellow of the Royal Academy of Music in 1898, and,

solution, so many theatrical depictions of one long systemically incurable succession of succession crises. 
as well as taking an interest in the English folk-song revival associated with Cecil Sharp and Ralph Vaughan-Williams, he was one of the first and keenest English disciples of Wagner, whose grandiose notions of a total theatre embodying the consciousness of a people he clearly sought to emulate. Parker had also established himself as a successful West End playwright, enjoying a transatlantic hit, for example, with his costume drama The Cardinal (1903). Just as importantly to his subsequent career handling large and potentially mutinous crowds as a pageant-master, Parker had also spent nineteen years as a schoolteacher, at Sherborne School in Dorset. Sherborne was one of a number of private schools involved in the educational outdoor revival of Greek tragedy, a form which for Parker and other pageant-masters, as for Wagner, constituted an enabling precedent. ${ }^{5}$ It was in celebration of the $1200^{\text {th }}$ anniversary of its foundation that Parker devised his first historical pageant, staged among the ruins of the town's Norman castle in the summer of 1905 by a cast of some 900 local volunteers, with all the profits from its 2,00o ticket sales per show donated to local charities (Goodden 1905; Parker 1905).

This massive theatrical
spectacle attracted extensive
national press coverage, and it
immediately caught the public imagination. Parker was promptly commissioned to devise another such show in Warwick the following summer, this one employing a cast of 2,000 and seating 5,000 spectators per show (Parker 1906). His ensuing Dover pageant of 1908 was on a similar scale (Parker 1908). By the end of 1909 Parker had also produced pageants for Bury St Edmunds, Colchester, and York. Liverpool, Potter Heigham, Oxford and St Albans, among many smaller

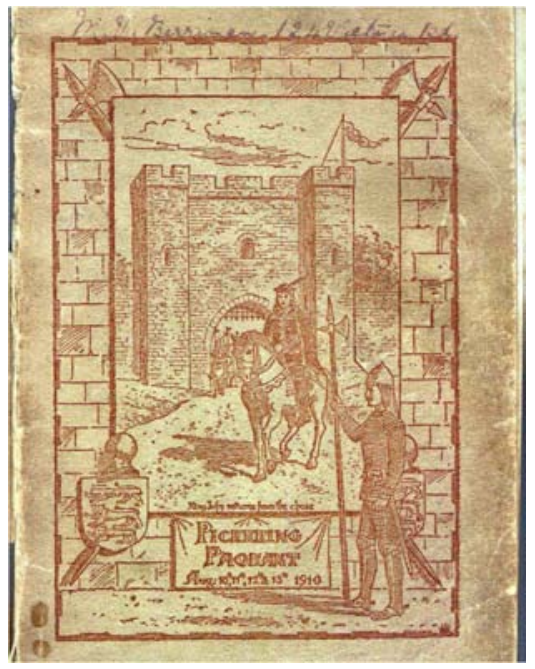

Figure 1. Cover of the Pickering Pageant script (Hudson 1910).

${ }^{5}$ On this movement and its influence on amateur Shakespearean performance see Dobson (2006). 
towns, staged their own in 1907; Chelsea, Cheltenham, Winchester and Pevensey theirs in 1908 (Withington 1918; Yoshino 2005; Ryan 2007). During the ensuing few years the vogue spread to ever further reaches of the kingdom. In the week of August $10^{\text {th }}-13^{\text {th }} 1910$, for instance, a pageant mainly scripted by one Gilbert Hudson was staged "in the historic ruins of Pickering Castle" in North Yorkshire, in what the published script-come-programme (fig. 1) makes clear was a concerted bid to attract more visitors to this little-known market town (fig. 2, fig. 3). Such
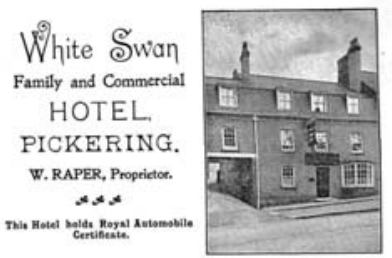

Pageant đeeer.

LUNCHEONS, DINNERS. AND TEAS. FROM 12 OCLOCK.

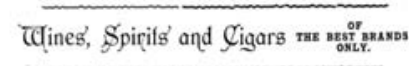

earriages meet all Jrains

To convey Visitors to the Grounds at reasonable charges. pageants continued to be staged down to the outbreak of the Second World War: E.M. Forster scripted two, Abinger Pageant (1934) and England's Pleasant Land (1938), which would provide part of the inspiration for the Poyntz Hall pageant at the centre of Virginia Woolf's novel Between the Acts (1941) (Esty 2003:4654).

Figure 2. Advertisement for the special arrangements made by the White Swan hotel for the accommodation of those visiting Pickering to see the 1910 pageant (Hudson 1910).

Figure 3. Dr R.L. Kirk and other cast members driving about Yorkshire in Kirk's prize-winning Talbot car "Old Reliable" advertising the 1910 Pickering pageant. Kirk is the driver, in the medieval helmet.

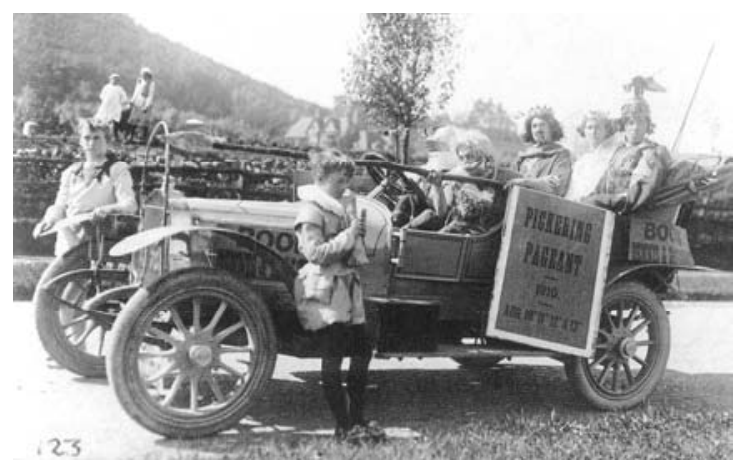

In essence, as Roger Simpson has observed, the pageant as created by Parker is "a chronicle play in which a social body rather than an individual is the hero" (Simpson 2008:63). As a genre, it extends the reach of the Shakespearean history play chronologically 
to something getting back towards that of the mysteries -the Warwick pageant covers 2,000 years instead of a mere 150- but it narrows that scope geographically, dealing not with Mankind or the English monarchy but with the development of a single local community. Despite its thirty-year heyday, the form didn't evolve much, partly because few individuals other than Parker, Frank Lascelles and Mary Kelly, author of How to Make a Pageant (1936), ${ }^{6}$ ever dared attempt more than one (Kelly 1934:737). ${ }^{7}$ But one other reason for the way in which the overwhelming majority of these shows follow exactly the recipe pioneered by Parker at Sherborne is simply that he got it right first time. As far as the Edwardian provinces were concerned, this sort of event presented the pageant of their history just as they wanted to see and understand it. Mary Kelly describes the usual pattern perfectly:

The majority of pageants resemble each other as closely as peas. There is the Spirit of the Ages dressed in grey-blue, or Father Time, or some character, who "narrates" (usually in rather halting blank verse) between the episodes, to explain what they are about. There are the Episodes: The Romans occupying Britain, The Founding of an Abbey, An Olde Englyshe Fayre, The Visit of Good Queen Bess ... and so on; ending with a great round-up of Spirits, of Peace, of Harmony, of the District Nursing Association, the Boy Scouts, the Women's Institutes, the British Legion, and a number of other associations, followed by all the performers, all singing "Land of Hope and Glory." (Kelly 1934:689)

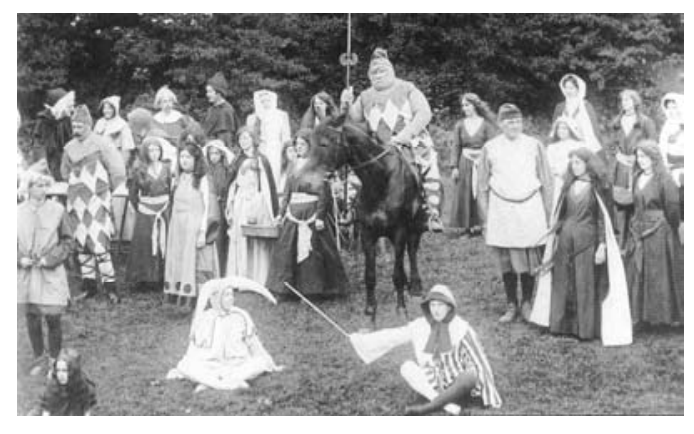

Figure 4 .

The Fair Scene, Pickering Pageant, 1910, starring Councillor Robert Dobson (mounted).

\footnotetext{
${ }^{6}$ This book is in fact merely a slightly expanded paraphrase of Kelly (1934).

${ }^{7}$ On Kelly, see especially Wallis (2006:102-8).

${ }^{8}$ The Fair Scene was a particular highlight of the Pickering pageant (Hudson 1910:2631, fig. 4), and was repeated by popular request at the Grand Pickering Gala on July $26^{\text {th }} 1911$.
} 
As Kelly's account suggests, the form of the pageant was by its very nature euphoric. The community that is any given pageant's subject is self-evidently alive and well at the end of the story and proudly re-enacting iconic episodes from its own history. In the pageant, the Shakespearean chronicle play's juxtaposition of tragic kings against comic people is simply transposed, to produce instead a juxtaposition of potentially tragic important visiting metropolitans, often monarchs, against mainly comic and perpetually enduring locals, both yeomanry and gentry. ${ }^{9}$ The pageant, though, could offer something that Shakespeare's histories could not -even when they were staged by $\mathrm{H}$. Beerbohm Tree with immense processions designed by Parker himself in return for loans of stage armour for his pageants. That was, to quote Parker's American disciple Percy Mackaye, "drama of and by the people, not merely for the people" (1916:xviii): the site-specific re-animation of the local past through collective amateur spectacle. That spectacle, with the bulk of the audience sheltered and immobilized in a temporary grandstand, inevitably consisted very largely of successive processions, characteristically seen approaching across long distances. If castle ruins weren't available as a backdrop, Mary Kelly recommended using wood-fringed spaces featuring reflective bodies of water, which might redouble the visual effect (fig. 5). She was particularly keen on employing horses, preferably ridden by expert members of the local hunt -Humans may fail to get the drama across, she observes, but horses never do (Kelly 1934:786,929). The re-enactment

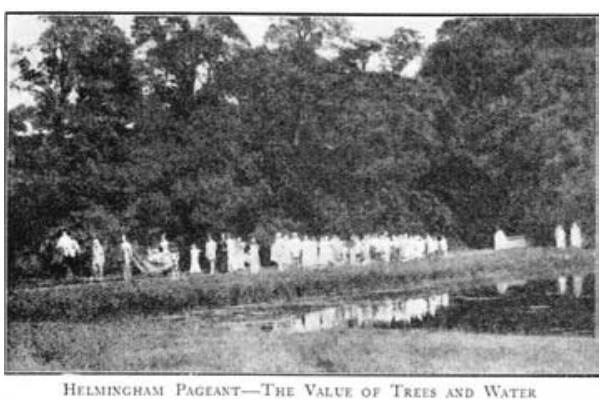
of the triumph, in short, was being re-enacted yet again.

Figure 5. Mary Kelly's illustration of an ideal pageant setting, drawn from one of her own projects. "Helmingham Pagean - The Value of Trees and Water"

Kelly (1934:736).

\footnotetext{
${ }^{9}$ For a case-study in the local politics of all this, see Woods (1999).
} 
As for what historical incidents these processions should dramatize, most pageant-masters shared a sense of the canon of recognizable English history which they had imbibed from a combination of Shakespeare, the Britannia section from Caesar's Gallic Wars, and the works of Sir Walter Scott. After their brief forays into prehistory, the Warwick and St Albans pageants, for example, included substantial excerpts from the Henry VI plays, about Warwick the Kingmaker and the battle of St Albans respectively, while the Dover pageant somehow found a pretext for incorporating parts of Henry $V$-Parker's Warwick pageant, incidentally, also incorporates the arraignment at Warwick of Piers Gaveston from Marlowe's Edward II, the only stage history which that controversial play would have for many years. The spirits of History and Imagination who compere the Pickering pageant, similarly, after giving us a bad king John straight out of Ivanhoe, depict Richard II confined in Pickering castle, where he quotes verbatim from Shakespeare's play about himself (in between, he is obliged to endure a local jester, and a choir of Yorkshire maidens who sing him "Sumer is icumen in") (Hudson 1910:39-44).

What is especially striking about most of these pageants is the prominence they give to the Tudor period, especially the reign of Elizabeth. Dover varies the pattern slightly by producing a youngish Henry VIII showing the harbour fortifications to Katherine of Aragon. But Warwick and St Albans both feature immense processional guest appearances by an Elizabeth and her court straight out of Kenilworth.

The last episode of the Sherborne pageant is set in 1593, when Sir Walter Raleigh comes home to his manor and has his tobaccopipe extinguished by an anxious servant, while Parker's 1907 pageant at Bury St Edmunds culminates with a recreation of Elizabeth I's visit in 1578. Likewise, although brave queen Bess couldn't appear in person at Pickering because everyone knew she had never risked travelling that far North, the final scene enacted there in 1910, as in several other Edwardian pageants, depicted news reaching the town of the defeat of the Spanish Armada in 1588. The last words of dialogue proper, before the choric spirits begin their concluding fourteeners and the assembled company sing "The Song of Pickering" and "O God our help in ages past," are "God save our gracious Queen Elizabeth!" -at which "Banners [are] displayed," 
there are "Trumpetings, shouts and cheers," and "Girls dance" (Hudson 1910:49). ${ }^{10}$ After the Elizabethans, apparently, unless your town was picturesquely involved in the Civil Wars as dramatized in Scott's Woodstock, all was anticlimactic, pageantry-free modernity, and hardly worth staging. ${ }^{11}$ As a result, almost all of Mary Kelly's specific advice on how to cast a pageant concerns how to get the right person for "the familiar Queen Elizabeth scene" (Kelly 1934:930,931). It's as if in lieu of having a formally-recognized national costume in which to dress up on special occasions, the English simply resort to farthingales and doublet and hose as an instinctive default setting.

When Parker himself cashed in on the success of his outdoor triumphs by composing a comparable show for ordinary commercial presentation, it was, predictably, another Tudor spectacular. Drake: A Pageant Play in Three Acts was produced by Beerbohm Tree at Her Majesty's in 1912, and was then successfully revived soon after the outbreak of the First World War. It finishes with one of Parker's signature huge processional crowd scenes, this one representing the victory parade to St Paul's after the repelling of the Armada:

[...] the People all turn towards the QUEEN and DRAKE with outstretched arms. CRIES: "God Save the Queen!" - "God Save Drake!" - "God Save England!" - Flags are waved. Roses are tossed on high, trumpets blare, bells clash, and the sun quivers on the QUEEN and DRAKE. (Parker 1912:67)

In a less exalted mood, E.F. Benson's fictitious pageant in Mapp and Lucia (1931) similarly centres entirely on Elizabeth and her favourite sea-dog. The comparatively unambitious Riseholme pageant depicted by Benson simply consists of Elizabeth knighting Drake on a replica of the Golden Hind specially built in the village pond -hence plenty of greenery and reflective water- and then, cued by a messenger announcing the approach of the Armada, processing across the road to make her 1588 Tilbury speech outside the local pub.

10 "The Song of Pickering" was published commercially by Novello and Sons of London, independently of the pageant's text, presumably in a further attempt to raise the profile of "Hill-guarded Pickering, / Queen of our Vale!" (Hudson 1910:55-6).

${ }^{11}$ More recent history could be left to Noel Coward, whose Cavalcade (1931), and This Happy Breed (1939) are essentially pageant-like chronicles of representative families instead of representative towns. 
Why this preoccupation with Elizabeth in the early twentiethcentury pageant? One local reason is that these shows, town-specific though they may be, partake extensively in contemporary enthusiasm for the British Empire (in the finale of the Warwick pageant, for instance, Britannia was attended by pages who each bore flags bearing the name of a British colony), an empire of which Gloriana was widely regarded as the founder. Kitty Barnes' 1931 pageant involving Elizabeth, Drake and Raleigh, for example, Adventurers, was specifically composed for performance by children on Empire Day (May 24), and even the inter-war armed forces shared this imperial enthusiasm for reliving the days of Elizabeth. Composers of pageants sometimes remarked that in both practicalities and aesthetics the form was closely analogous to the military tattoo (Kelly 1934:931), and the convergence is noticeable in both genres. At the culmination of the Sherborne pageant, for instance, in a striking anticipation of a subsequent quasi-military rally in another country, the entire cast, having assembled to the strains of Wagner's march from Tannhauser, all saluted in unison and shouted "Hail!"12 Similar effects characterized the "Pageants of Victory" staged in some towns to mark the conclusion of the First World War. Oxford's, incidentally, depicting each of the allied nations in turn, got right back to the roots of the pageant when it represented Italy by a re-staging of Petrarch's triumphal procession through Rome to be garlanded with laurels. It also enlisted the Bard, representing France, perhaps tactlessly, by a lavish re-enactment of the betrothal ceremony of Katharine de Valois and Henry V at Troyes using dialogue from the last scene of Shakespeare's play (de Bergerac 1919:25-27,21-23). ${ }^{13}$ This military enthusiasm for Henry $V$ lasted for some time: the Army's tattoo at Aldershot in 1930, for instance, incorporated an abbreviated pageant adaptation of the battle scenes, which to judge from surviving photographs looked remarkably like an anticipation of Laurence Olivier's 1944 film. This episode was followed by yet another grand processional pageant entry by Gloriana, this time impersonated by a soldier. At Aldershot she may have had the body of a weak and feeble woman, but she

\footnotetext{
${ }^{12}$ Given the widespread use of pageantry by subsequent totalitarian regimes of both right and left, it is worth considering whether the form Parker pioneered helped to encode and bequeath the megalomania inherent in high British imperialism.

${ }^{13}$ Petrarch, watched by Laura, recites one of his sonnets in Spenser's translation. This pageant also features the standard Elizabethan revels, here located at Banbury.
} 
had the heart and stomach of an officer and a gentleman. ${ }^{14}$ Despite the alarms and excursions of the First World War, apparently, in the 1930s Elizabeth's victory in 1588 still marked a convenient happy ending, the point after which there were to be no more defining wars for national survival.

As this reading may suggest, the pageant was committed to a view of the past if anything more providential than that of Shakespeare's histories. Sherborne, Warwick and even Pickering were clearly always destined to flourish, just as the island nation as a whole was set aside for victory and security. "It is best to end on a note of joy or hope," advised Kelly, since for her the pageant was committed to a post-Enlightenment faith in the inevitability of progress: the ultimate subject of any worthwhile pageant, she explained, was "the gradual growth of the human mind" (Kelly 1934:691-692) -hence the occasional adaptability of the pageant to progressive causes, as in the case of E.M. Forster's liberal environmentalism, or Cicely Hamilton's suffragette play A Pageant of Great Women, 1910. That faith in improvement and change, however, was always counterbalanced by a deeply conservative assertion of continuity. In practice the implicit argument of the English local pageant is that Pickering always has been Pickering and always will be, forever peopled by the same townsfolk whatever successive fancy dress costumes they may put on. Even the first, prehistoric episode in Gilbert Hudson's 1910 pageant, a sort of small-scale rape of the Sabine women wordlessly enacted between "uplanders" and "shore-dwellers" beside a body of water which had ceased to exist long before the town was founded, calls its location "Lake Pickering" (1919:3-4).

Mary Kelly, when not involved with pageants, devoted herself to the rediscovery, or reinvention, of an English tradition of indigenous folk drama, derived from the mummings and Whitsun pastorals fleetingly mentioned by Shakespeare. Her own sense of how pageants should best be cast was at times not just nativist but explicitly genetic. Arguing against the custom of giving major, royal roles to local aristocrats, for example, she suggests that "The best

\footnotetext{
${ }^{14}$ Photographs of this event are preserved in the National Army Museum library in Chelsea; see NAM 1990-07-31.
} 
place for the County is in the representation of its ancestors." ${ }^{15}$ Whatever the script may suggest about historical change, then, the performance of a historical pageant will give the impression that the same lord of the manor has always been the lord of the manor, even if over the centuries he has been something of a serial fashion-victim. To this extent the Edwardian pageant, like the medieval, suggests that human history is essentially trivial. It is full of gorgeous trappings, processing harmlessly past in sequence, but ultimately and perhaps consolingly- it alters nothing. Coronations may come and civil wars may go, but the replication of the same local families goes on forever.

Given this sense of genetic inheritance, it is appropriate that for Parker, Kelly and their colleagues the major pre-Tudor events not pre-digested by Shakespeare and Scott which a pageant might need to register were invasions. Needing an example of crowd dialogue, for instance, Kelly immediately reflects that "fugitives may cry the names of their pursuers, 'The Norsemen! The Norsemen! The Black Danes are coming!'” (Kelly 1934:736). (In this respect as in others these pageants also resemble Rudyard Kipling's popular children's book Puck of Pook's Hill, 1906, in which the spirit-master-ofceremonies who shows two children episodes of local history involving their nation's ancestors is Shakespeare's Puck himself). To the makers and consumers of English pageants, apparently, history consisted largely of the Romans sailing across, interbreeding and taking over, then the Saxons sailing across, interbreeding and taking over, then the Vikings sailing across, interbreeding and taking over, then the Normans sailing across, interbreeding and taking over, and then the Spanish Armada sailing across and not even managing to land. After which history was over, since German threat or no German threat there were to be no further changes to the ethnic identity of the English shires.

\section{Pageant into Cinema}

Change came in the Edwardian period, even so, including the development of new communications technologies. From the outset,

\footnotetext{
15 "[...] they can wear lovely clothes, and heraldry, and so on, and feel themselves as important as the principals" (Kelly 1934:930).
} 
pageants provided an irresistible subject for the owners of cine cameras, and footage survives from a number of these events (notably Warwick), albeit rather inaccessibly in local history archives. With the coming of sound cinema in the 1930s, though, film could suddenly deliver spectacle, dialogue and music to larger audiences even than those which came to Warwick or Dover. The new medium, however, did not immediately wipe out the pageant: it was merely that the pre-war talkies cannily adopted elements of the historical pageant as part of their stock-in-trade. The first internationally successful British sound film was that swaggering pageant Alexander Korda's The Private Life of Henry the Eighth (1933), and in 1937 Korda went on to produce Fire over England. Adapted from A.E.W. Mason's novel, this film, like any self-respecting pageant, reaches its climax with Elizabeth's visit to Tilbury in $1588-$ a sequence which begins with a long equestrian processional entry past woods and water of which Mary Kelly would have been proud. The link between the early costume movie and the pageant is even more obvious in another of this film's forbears, made two years earlier. Arthur B. Woods' Drake of England (1935) was simply a film adaptation of Louis Napoleon Parker's very own Drake. Sadly, it is now almost impossible to obtain Drake of England outside the archives of the British Film Institute. However, a less elusive direct successor goes one better than Parker, by not just providing the knighting, the Tilbury oration and the victory celebrations, but by compressing all three into one culminating crowd scene. In 1940, Michael Curtiz made The Sea Hawk, with Errol Flynn as the fictitious Geoffrey Thorpe and Flora Robson again playing Elizabeth. Thorpe is rewarded by the Queen for intercepting Spanish intelligence and warning of the approach of the Armada, in a finale of pure pageantry which neatly conflates the knighting of Drake, a topical paraphrase of the Tilbury speech, and the flag-waving and cheering of the Armada victory.

In Errol Flynn's other Elizabethan costume drama, however, the attitude to pageantry is very different, largely because the spectacle is designed for the consumption of a different national audience. Although Mary Kelly had advised canny business managers that "The interest in pageants is particularly great in America, and it is well worth advertising in the American shipping lines" (Kelly 1934:1035), in practice catering to an American perspective on the English past might prove fatal to most of the form's founding 
assumptions. While in 1905 the inhabitants of Sherborn, Massachusetts had sent a letter to Sherborne, Dorset, boasting of their "filial pride" in the "mother town" (Goodden 1905:15-17,27-28), Americans now increasingly saw their history not as a continuation of England's but as marking a complete ideological break from it: for them, established modernity now began not in 1588 but in 1776 . The early Technicolor spectacular The Private Lives of Elizabeth and Essex (1939), admittedly, begins in pure Parker mode, with a long Renaissance procession which is explicitly a triumph, and according to one spectator a Triumph of Love at that, as Essex parades through London after his victory at Cadiz eager to be reunited with his queen. But despite this public opening, this film's Elizabeth, unlike Flora Robson's, is strictly an indoor person, always shown in court settings within which the macho, outdoor Essex feels increasingly confined. She is never granted any such antique tickertape parade as his, and ultimately the film disowns Elizabeth, English history and pageantry alike. Essex grows out of all that pomp, yearning for a sincere man-to-man republic elsewhere, and in the end he chooses to accept execution quietly and off-screen rather than tolerate his subjection to an overdressed royal mistress any longer. In Hollywood costume drama like this, it isn't the crowd that represents us but the juvenile leads (here Essex and the young Penelope Rich, but not Elizabeth), who are usually as incongruously ahead of their time as a Connecticut Yankee at King Arthur's court. Much the same point is made in Bette Davis's second Tudor film, The Virgin Queen (1955). The film uses one canonical episode of courtly processional favoured by several pageants (the anecdote of Raleigh laying down his cloak for his queen in a puddle), but its perspective is ultimately anti-court, on the side of a Raleigh whose disregard for his cloak is based not on supreme courtiership but on the contempt for archaic frippery proper to a proto-American man of action. At the end of the film, Raleigh too leaves Elizabeth, sailing off to found Virginia with Joan Collins. ${ }^{16}$

In the post-war period, as this Hollywood film suggests, the triumph really belonged to American modernity rather than to English history, and in Europe too approaches to the early modern past were changing. The definitive public events designed to assert a continuity with the Renaissance were now not nationalistic

${ }^{16}$ On these films, see Dobson and Watson (2002:275-82). 
processions but international arts festivals, often centred on the revival of Shakespeare: the festivals at Edinburgh, Avignon, Verona, and so on were all founded in the 1950s, and several of them, as Dennis Kennedy has pointed out, were inaugurated with grand ceremonial productions of Richard II (Kennedy 2003). Similarly, the scholarly recovery of early modern court occasions, which underwent another periodic renaissance of its own from the 1960s onwards in the work of Stephen Orgel and others, now concentrated less on the militant processions of Queen Elizabeth than on the court masques of her pacific successor, James I. In England during the post-war "New Elizabethan" period, it was the festivals of the Renaissance rather than its triumphs which were to be revived, whether as cod "Renaissance Fayres" for the masses, as May Day celebrations for schoolchildren, or as more arcane shows for the elite. When Princess Elizabeth and her sailor husband Prince Philip visited Oxford in 1948, for instance, they were entertained not with a pageant about the victories of Drake but with a pastiche of an Elizabethan court entertainment, the rather strenuously optimistic Masque of Hope (Dobson and Watson 2002:76-8,231). The military tattoo aspect of the historical pageant now survived mainly among specialist clubs dedicated to re-enacting battles, such as the Sealed Knot. A few pageants were still staged in small villages, particularly around the time of the Festival of Britain, including one at Naphill in Buckinghamshire, but it was hard for them to muster the sort of budgets enjoyed by Parker in the glory days: this one was unable to afford more than Elizabeth's court and St George and the Dragon. ${ }^{17}$

But after the Blitz, in any case, as Woolf had already recognized in Between the Acts, it seemed much harder for the English to go on thinking of history as a providential fancy dress procession that was all about them but which they could simply sit back and savour as it passed by. As the Empire visibly imploded, moreover, it became impossible to celebrate its inevitable long-term triumph, and in the decade that saw race riots in Notting Hill, the days of a form that had believed that the Tudors had permanently indemnified not just the English Channel but the English gene-pool were clearly numbered. Despite its medieval Christian phase as an exposé of

17 See http://apps.buckscc.gov.uk/modes/projects/SWOPimage/RHW5061o.jpg; http://apps.buckscc.gov.uk/modes/projects/SWOPimage/RHW50614.jpg. On the later phases of the pageant-play, see especially Esty (2003). 
worldliness, as I've shown, the pageant as a dramatic form had remained faithful to its classical roots in the celebration of imperial triumph all along, and that triumph had now, in the best classical tradition, migrated westwards. For the post-war British, history was no longer a pageant -except, perhaps, in the sense in which Shakespeare had used the word all along. As Puck had put it: "Shall we their fond pageant see? / Lord, what fools these mortals be!" ( $A$ Midsummer Night's Dream 3.2.114-115).

\section{References}

Beard, Mary 2007. The Roman Triumph. Cambridge, MA: Harvard University Press.

De Bergerac, Bernice 1919. The Oxford Pageant of Victory, 1919. Oxford: Vincent Works.

Dobson, Michael 2006. "Shakespeare exposed: outdoor performance and ideology, 1880-1940." Ed. Peter Holland. Shakespeare, Memory and Performance. Cambridge: Cambridge University Press: 256-280.

Dobson, Michael, and Nicola Watson 2002. England's Elizabeth: An Afterlife in Fame and Fantasy. Oxford: Oxford University Press.

Esty, Jed 2003. A Shrinking Island: Modernism and National Culture in England. Princeton, NJ: Princeton University Press.

Goodden, Cecil B. 1905. The Story of the Sherborne Pageant. Sherborne: Bennett.

Hudson, Gilbert 1910. The Pickering Pageant. Pickering: Boak and Sons.

Kelly, Mary 1934. "Pageants." Ed. Harold C. Downs. The Theatre and Stage. 2 vols. London: Pitman. II: 689-692, 735-738, 783-786, 833-836, 881-884, 929932, 981-984, 1035-1038.

Kennedy, Dennis 2003. "Shakespeare and the Cold War." Eds. Angel-Luis Pujante and Ton Hoenselaars. Four Hundred Years of Shakespeare in Europe. Newark: University of Delaware Press: 163-179.

Mackaye, Percy 1916. Caliban By the Yellow Sands. New York: Doubleday.

Parker, Louis Napoleon 1905. The Sherborne Pageant. Sherborne: Bennett.

Parker, Louis Napoleon 1906. The Warwick Pageant. Warwick: Evans and Co.

Parker, Louis Napoleon 1908. The Dover Pageant. Dover: Grigg and Sons.

Parker, Louis Napoleon 1912. Drake. A Pageant Play in Three Acts. London: John Lane. 
(9)ederi 20 (2010)

Ryan, Deborah Sugg 2007. "'Pageantitis': Frank Lascelles' Oxford Historical Pageant, Visual Spectacle, and Popular Memory." Visual Culture in Britain 8/2: 63-82.

Simpson, Roger 2008. "Arthurian Pageants in Twentieth-Century Britain." Arthuriana 18/1: 63-88.

Wallis, Mick 2006. "Drama in the villages: three pioneers." Eds. Paul Brassley, Jeremy Burchardt and Lynne Thompson. The English Countryside Between the Wars: Regeneration or Decline?. Woodbridge: Boydell and Brewer: 102-115.

Withington, Robert 1918. English Pageantry: An Historical Outline. 2 vols. Cambridge, MA: Harvard University Press.

Woods, Michael 1999. "Performing Power: local politics and the Taunton pageant of 1928." Journal of Historical Geography 25/1: 57-74.

Yoshino, Ayako 2005. The Edwardian historical pageant. Cambridge Ph.D.

\section{Sources for the illustrations}

1. The cover of the Pickering Pageant script (Hudson 1910), formerly owned by M.V.Berriman (Writers' Resources, Oxford).

2. Advertisement for the special arrangements made by the White Swan hotel, from Hudson 1910 (Writers' Resources, Oxford).

3. Dr R.L. Kirk and other cast members driving about Yorkshire. Beck Isle Museum, Pickering, courtesy of Gordon Clitheroe.

4. The Fair Scene, Pickering Pageant, 1910. Beck Isle Museum, Pickering, courtesy of Gordon Clitheroe.

5. Mary Kelly's illustration of an ideal pageant setting. Kelly (1934:736) (Writers' Resources, Oxford).

How to cite this article:

Dobson, Michael. "The Pageant of History: Nostalgia, the Tudors, and the

Community Play." SEDERI 20 (2010): 5-25.

Author's contact: m.dobson@english.bbk.ac.uk

Submission: 03/08/2009

Acceptance: 26/12/2009 


\title{
"I have written the things which I did hear, see, tasted and handled:" Selfhood and Voice in Katherine Evans' and Sarah Cheevers' A Short Relation of Their Sufferings (1662)
}

\author{
Carme Font Paz \\ Universitat Autònoma de Barcelona
}

\begin{abstract}
This article analyses the representation of selfhood in a major Quaker autobiography, A Short Relation (1662), written by Katharine Evans and Sarah Cheevers; the analysis will try to assess, through a detailed discussion of the voices in the text, the dynamic female selfhood that emerges from it and its main constitutive elements. Secondly, and with the help of Evans' and Cheevers' private correspondence, the article contextualises this notion of selfhood in the social space of early Quakerism in order to assess the extent to which it was informed by the Quaker emphasis on gender equality before God and women's relationship to the divine. At the same time, this analysis invites us to regard $A$ Short Relation as a major early modern autobiography that may be particularly challenging to presentday Gender Studies.
\end{abstract}

KEYWORDS: Quakerism, early modern women writing, autobiography, gender, prophetic writing.

\section{Introduction}

To a certain extent, research is still catching up with the multiplicity and variety of early modern autobiographical writings by women. This is particularly true in the case of religious writings: even though research in this area has multiplied over the last two decades, the challenges posed by these texts keep compelling us to reassess our preconceptions of what "women's writing" is, and of what it has been over history. No doubt this is as a result of the 
enormous variety of these materials: along with the general impulse given to writing by the spread of Protestantism, there were multiple (and often incompatible) traditions of belief that developed in Britain during the sixteenth and seventeenth centuries; the very act of writing revealed diverse meanings and connotations in each of these traditions, and this applies to the concept of "self" expressed in autobiographical texts too. As a consequence, it is difficult for scholars to generalise: each tradition of writing seems to require a different methodological approach and perspective from which to appreciate and understand it. Hilary Hinds in her thorough study God's Englishwomen presents a middle ground in the theoretical approach to sectarian writing in the early modern period by acknowledging the importance of both historical contextualization and a literary analysis which allows its inclusion in a long line of women's writing (Hinds 1996:14).

Writings by early Quaker women seem to be particularly resistant to our modern (or post-modern) concepts of woman's writing; as Suzanne Trill puts it, any attempt to search "for a uniquely female voice in these texts runs counter to the Quaker's aspiration to merge the self with God" (1997:45). Certainly, most of the early texts written by Quaker women invite the reader to seek "the Light," the illumination of the self which can make it one with the Holy Spirit; any other aim or purpose within them is always subordinated to that primary intention. The writings of Margaret Fell (1660), Katharine Evans (1662), or Hester Biddle (1660), for instance, were not essentially concerned with the condition of women, but with the affirmation of the will of God to expand the community of believers. On the other hand, and from a strictly theological perspective, Quakers believed in an equal access to "the Light" both for men and women, and because of this female authors such as Fell or Biddle were able to speak with a strong sense of authority: in theological terms, their gender was no obstacle to becoming receptacles of the voice and authority of God.

Women were particularly suited to adopting this prophetic role, since their biological construct as "vessels" and "recipients" enabled them to act as perfect channels for God's speech. Phyllis Mack supports this view by remarking that characterising the female "visionary" as an empty vessel cannot be easily termed "misogyny." In fact, she reminds us that: 
The defects of rationality and the attuned intuition of visionary women were actually viewed with respect, even envy, by those philosophers who felt alienated from God by their compulsive, prideful reliance on the power of their own reason. Indeed, in this respect all women had a clear spiritual advantage over men, for the static resulting from their weak and intermittent surges of intellectual energy was less likely to interfere with their capacity to act as receptors for the divine. (Mack 1994:33)

This emotional quality of women which makes them receptive and intuitive channels is appropriate for the expression of spiritual values. Prophetic writing may thus appear as intimately related with the feminine because it requires from the prophet an emptiness, a passivity, which was necessary to prophesise.

Yet, as readers of early modern literature we cannot forget that the simple fact of writing and speaking in public was, for these women, fraught with difficulties and dangers. ${ }^{1}$ Even when early Quaker texts by women do not make a point of gender distinctions, that difference is nevertheless inscribed in them, especially in the most directly autobiographical materials. It may not appear in the voice of the women authors themselves, but certainly in the voices of their adversaries. Catie Gill articulates this view by considering these texts as recipients of the anxieties that surrounded women's public expression of faith, and argues that "the voice these women claim when writing about punishment, then, is often directly or indirectly a response to others' ineffective attempts to silence them" (Gill 2009:259). Gender differences are indeed present in the texts by Margaret Fell or Katharine Evans, even if they are not recognised as such by these authors: they are presented, rather, as instances of the corrupt structures of the Fallen world, as examples of the power of sin against which the believers have to stand as testimonies of faith. Early Quaker literature by women thus offers a unique dialectic which can be taken as a challenge to Gender Studies and its analytic tools: in these texts, the egalitarian discourse of Quakerism clashes with the patriarchal structures of seventeenth-century society; but

\footnotetext{
${ }^{1}$ John Ray Knott argues that Quakers were the religious community which, soon after the Restoration, and despite Charles II's moves towards toleration, suffered most from the backlash against sects, with the passing of the Quaker Act instituting penalties for refusing to take the oath of allegiance and with the close surveillance of the printing presses. Knott notes that Quakers both suffered most and as a sect did more to record and publicize their suffering than any other group (1993:216-217).
} 
even as these clashes are registered, they seem not to affect the sense of identity of their authors, who, as we will see in this article, remain firmly identified with the will of God and rarely acknowledge or rebuke the validity of social differences.

\section{Aims and Methodology}

A Short Relation by Katherine Evans and Sarah Cheevers (1662) belongs to the tradition of autobiographical narratives written by religious dissenters which would become quite popular in the $1660 \mathrm{~s}$ and 1670 . There is now an increasingly broad scholarly consensus that these modes of autobiographic narration became especially important in the Restoration (Hinds 1996; Wiseman 1992; Feroli 2006; Gill 2005), when the links between the different dissenting communities, in England and abroad, had to be strategically reinforced. A Short Relation therefore operates, like other works of its kind, on two different and complementary levels: as an account of individual subjectivity (through the voice of Katharine Evans that predominates in the text) and as a product for religious consumption, meant to strengthen the ideology and the practices of the community it addresses. This interplay between the voice of the individual and its intended audience (the religious group) creates a dialectic that is specifically characteristic of early modern Quaker culture, and of the ways in which female authority could be established within it. A Short Relation, nevertheless, goes much further, since the text manages to present a viable model for the configuration of selfhood that is representative of the flexibility and dynamism of seventeenth-century religious female writing.

Rather than focusing on the narrative content of $A$ Short Relation, this article will pay attention to the articulation of forms of subjectivity within the text. Throughout the narrative, we not only find a single individual perspective (the "I" of Katherine Evans) but also a surprising variety of voices that constantly interrelate, address and interrogate one another. This plurality of voices in the same text is what gives a unique quality to A Short Relation, as the voice of Katherine Evans, her perspective and her interpretation of her experience are actively generated, created, in this multi-vocal textual space. This article, therefore, offers a detailed analysis of the literary 
construction of self and subjectivity within a text that is dynamic and multiform, yet fully coherent in its message and purpose.

What makes A Short Relation stand out among other autobiographical narratives produced in the same context is the dynamic interplay that is generated, all through the text, between a wide variety of voices: the voices of the Quaker women protagonists, those of their Catholic opponents, and even that of the Spirit, which makes itself openly present in the text, differentiating itself from the rest of speakers. The following pages explore this rich multi-vocality, establishing the way it relates to the sense of selfhood and religious identity presented in the text, examining the extent to which it contributes to (or detracts from) the prophetic authority claimed by Evans and Cheevers. Catie Gill has acknowledged the centrality of this multi-vocality pointing out that "Quaker women's speech patterns are of particular importance in understanding the textual representation of their suffering" (Gill 2005:259).

Due to their significance, Mikhail Bakhtin's theory of dialogism and some of its corresponding terminology will be used to discuss the various voices and accents in the text. My intention in doing this is not to postulate the Bakhtinian model as necessarily being the most appropriate for the analysis of early modern autobiographies by women; rather, Bakhtinian categories will be employed as useful tools for a better understanding of the stylistic levels of $A$ Short Relation. The Russian theorist concentrated especially on the development of stylistic plurality and variety in literary developments from the Latin Middle Ages to the creation of the modern novel; the early modern period, with its many moments of transition between different forms of religious culture, and between the sacred and secular worlds, was repeatedly presented by him as a historical moment of decisive importance in the creation of literary models that were dynamic, dialectical and multiform, in contrast to their medieval predecessors -models that, in themselves, could be seen as belonging to the "prehistory of novelistic discourse" (Bakhtin 2996). The following section specifies the Bakhtinian categories that are most useful to the present analysis; suffice to say, for now, that these address some of the questions that $A$ Short Relation continues to pose today: How is subjectivity created in this text? How do its multiple voices relate to each other? How do these factors sustain prophetic authority, and is that authority gendered? 


\section{Prophetic Speech in the Context of Quaker Women's Writing}

Although A Short Relation cannot be regarded as a conventional autobiography, it nevertheless shares distinctive features with both prophetic writing and the autobiographical genre. Like thousands of women in the mid-seventeenth century, Evans and Cheevers were middle-class housewives who had received only the basic rudiments of education. Yet their involvement in the Quaker community empowered them in a particular way: it offered them direct, immediate access to the word of God and to the presence of the Spirit. In this regard, several scholars have noted the importance of Quaker autobiographical texts, in particular those written in captivity, in the moulding of a sense of community. For Catherine Gray, Quakers were adept in forging bonding relationships across and beyond geographical borders, to the extent that women draw on their private spheres in times of stress, prosecution or incarceration in order to ground their counterpublic activities:

A Short Relation thus depicts two women at the centre of a wider circle, itself figured by the kind of intimate language of family and friendship. They refer to fellow Quakers as "Friends," "Brethen and Sisters," and "Nursing Mothers of Israel." The intensity of the women's relationship inflects their affiliation with Baker in particular, who is presented as an intercessor on their behalf, an ecstatic reader of their manuscripts and another spouse. (Gray 2007:187)

Often, the proximity of sharing the same cause with other fellow members becomes the stimulus for engaging with ecstasy or for uttering prophetic speech in which the voice of the author in prison and the words of the Bible merge in a single purpose and discourse:

The Lord (who alone is our Life and Redeemer) moved our dear Brother to offer his own body to redeem ours, but it would not be received; then he offered to lay down his own dear and precious life for our liberty: Greater love can no man have, than to lay down his life for his Friend; the Lord will restore it into his bosom double; his service can never be blotted out; his Name is called Daniel Baker; his outward being is near $\mathfrak{Z}$ ondon, right dear and precious heart he is: The blessing, strength, and power of the Almighty be upon him and his, and overshadow them for ever, 
Amen. Greater comfort could never be administred to us in our conditions. (Evans and Cheevers 1662:62)

Evans and Cheevers explain how the Lord moved Daniel Baker to offer himself as a prisoner in exchange for the two women. Even the practical act of offering oneself for incarceration becomes an object of divine intervention. Their speech is prophetic not because the authors foresee the future or warn their leaders of imminent doom, but because their entire writing is coated with a spiritual meaning which Evans and Cheevers understand and relay to the world in writing. ${ }^{2}$ The sense of bonding reinforces the authority of prophetic speech and the voices of women authors within their communities. When they write "his Name is called Daniel Baker; his outward being is near London, right dear and precious heart he is: The blessing, strength, and power of the Almighty be upon him and his," they are making a distinction between Baker's outward body (the physicality of his body, which lives in London) and his spirit or heart, which is with them. Leaving aside the Antinomian and mystical Pantheist reverberations of the distinction between soul and body (Punshon 2006:41), Evans and Cheevers here are extending the geographical borders of their community and strengthening the prophetic character of their own selves and their salvic mission: suffering is, for these women, a form of bonding and articulating their prophetic message beyond the prison walls. Patricia Crawford argues in this regard that:

Quakerism offered transcendence. It was a mystical and ecstatic religion. Inspiration from the Holy Spirit moved the believer away from anthropomorphic conceptions of God. Women could seek to transcend both class and gender. They could refuse social deference, bowing only to the Lord, and they could, by working through their female nature, as they understood it, be at one with the divine, where difference of sex was immaterial. (Crawford 1993:180)

In other words, their identity (and emphasis) as women talking to God was less important for Evans and Cheevers than the fact that they, as individuals, were giving themselves up to the will of God. If we take Quaker women's writing as representative of the emergence of female voice and selfhood in literature, we realise that a basic

\footnotetext{
${ }^{2}$ Diane Purkiss has defined prophecy as "any utterance produced by God through human agency" (1992:139).
} 
notion of individuality had to appear before any kind of gender identity could develop. Elspeth Graham qualifies this view by saying that "autobiography and individualism both imply some sort of dialectic between the agency of the individual and awareness of the self, or self-consciousness" (Graham 2000:197). However, the early modern concept of the self was quite different from our contemporary post-modern notions of individuality; in the English society of the Renaissance and the Restoration, the self was not defined in terms of unconscious desires, even less in terms of physical appetites or urges. For Quakers, in particular, the self was closely defined by "conscience", seen as a fragment, or a part, of universal truth: it was God's own voice embedded in the self, a voice to which they also referred as "the light" or "the seed." The act of prophesying, on the other hand, had nothing to do with foreseeing the future: it had to do with transmitting the words and the will of God, engaging in communication with Him when the individual consciousness was prepared for it.

\section{The Voices in the Text}

Katherine Evans (c.1618-1692), from Inglesbatch near Bath, and Sarah Cheevers (c.1608-1664), from Slaughterford, Wiltshire, were travelling companions in the ministry, itinerant Quakers who preached their message throughout England and in other countries. Evans and Cheevers had been among the earliest Quaker missionaries to Scotland in 1653, and they were used to encountering opposition to their preaching activities. In 1655 Evans was banished from the Isle of Wight after enduring harsh insults and "many abuses from the rude people there" (Besse 1753:2.495), and later that year she was put on trial along with eight other Friends (including her fellow Quaker leader James Nayler) for visiting Quaker prisoners; this resulted in her imprisonment in Exeter in 1655. Despite all their various exploits and intense life, neither Evans nor Cheevers left a full autobiographical account of their conversion to Quakerism; all the available biographical data on these two women comes from $A$ Short Relation (1662) and from a much later work, Joseph Besse's A Collection of the Sufferings of the People Called Quakers (1753), a massive two-volume account of early Quaker preaching. Stefano Villani's entries on Evans and Cheevers in the Oxford Dictionary of National Biography, drawing on sources from the 
Archivio Segreto Vaticano and the Archivum Inquisitionis Melitensis in Malta, provide some further details on their prosecution and eventual release.

When in 1658 Evans and Cheevers undertook a sea voyage from England to Alexandria, Egypt, they knew that they were leaving behind their respective husbands and children (Evans' husband, John, was also a Quaker minister) to embark on a dangerous journey, yet there is no evidence that this was perceived by them as a challenge to their family life and status. On the contrary, as their private writings show, their strong commitment to Quakerism did not imply for them a denial of their status as beloved wives and mothers. ${ }^{3}$ The two women were bound for Alexandria, but when their ship put in at Valletta, Malta, they began to preach and distribute Quaker literature written in English and Spanish in the streets, even going so far as to interrupt a mass, which caused the intervention of the authorities. ${ }^{4}$ After being arrested, the two women were handed over to the English consul for safe-keeping, but the chief Inquisitor of the island ordered that they be moved to a prison, where they remained from April 1659 until July 1662. Several unsuccessful attempts were made by fellow Friends (notably George Fox) to convince the prison authorities of their innocence, and to secure their release. Among their most prominent visitors was also the Quaker leader Daniel Baker, who asked for their release and who, "in line with common Quaker practice, offered himself as a substitute prisoner" (Booy 2004:27); although his efforts to win their freedom were unsuccessful, Baker left Malta carrying several documents written by them and, back in London, he published the first version of their prison narrative, A Short Relation. Evans and Cheevers were finally released in September 1662, and reached England later that year. A Short Relation thus belongs to the subgenre of "prison narratives," an autobiographical form that together with death-bed testimonies and conversion narratives- was particularly cultivated by Quaker women, more than in other dissenter religious groups. Unlike the conventional "captivity narrative," which normally presents a story of people captured by

\footnotetext{
${ }^{3}$ In the letters addressed to their husbands, we typically find expressions such as: "My most dear and faithful Husband, Friend, and Brother" (Evans 1663:69), or "My Love, my life is given up to serve the Living God" (Cheevers 1663:73).

${ }^{4}$ At that time, Malta was ruled by the Roman Catholic Knights of Saint John.
} 
"uncivilized" enemies, "prison narratives" imply a spiritual renewal (Gill 2009).

Given the specificity of $A$ Short Relation, a few of the categories introduced by Bakhtin can be helpful when approaching a text that is as heterogeneous as this one. According to Bakhtin, the prehistory of novelistic discourse in the West was characterised by the presence of several "extremely heterogeneous factors at work;" among these were the presence of irreverent laughter, the relativisation of the authorial voice and, most especially, heteroglossia, the rich interpenetration and dynamic interaction of multiple and contrary voices within the same text. As Bakhtin observed, "the interanimation of languages made possible the genre of the novel" (Bakhtin 1981:78), and this remained the major characteristic of the novel until the nineteenth century, when it culminated in the great polyphonic works of Dickens and Dostoevsky. The defining characteristic of heteroglossia is, precisely, this rich and powerful interpenetration and inter-fertilisation of different voices and styles, which ultimately frustrates any possibility of establishing a hierarchy among them:

Different linguistic and stylistic forms may be said to belong to different systems of language [...] If we were to abolish all the intonational quotation marks, all the divisions into voices and styles, all the various gaps between the represented "languages" and the direct authorial discourse, then we would get only a conglomeration of linguistic and stylistic forms. (Bakhtin 1981:174)

Against the essential feature of heteroglossia, and in contrast to it, Bakhtin sets the concept of "monology" or monological discourse, which corresponds to any form of discourse or text that is controlled by a single, over-arching perspective. In such discourse, narrative is ultimately subordinated to a dominant voice or perspective which controls it, stabilising its meaning and interpretation; thus, monological uses of language tend to favour univocal world-views and to reduce the presence of different accents within them. As Michael Holquist suggests in his commentary, these uses of language tend to "privilege oneness: the more powerful the ideology, the more totalitarian (monologic) will be the claims of its language" (Holquist 1990:51-53). In this sense, it is worth paying attention to the articulation of the various voices in A Short Relation and whether it leads to ideological and stylistic openness 
(heteroglossia) or to a sense of dogmatic and formal closure (monoglossia).

Before concentrating on the text itself and its formal peculiarities, however, it is necessary to observe that the work that we designate $A$ Short Relation, is itself presented to the readership (that is, both to the Quaker community and to the occasional reader) by an external element: the introduction written by Daniel Baker. The presence of Baker's text can be read as a protocol that guarantees the truth of the experience narrated in the tract, and at the same time introduces a principle of extrinsic authority validating the voice of the women. Baker's voice disappears entirely after his preface, and is replaced by the autobiographical narrative by both women till the end; nevertheless, we must be aware of its strategic value. It is a male voice and an editorial voice, and these two factors legitimise, to a certain extent, the seriousness and credibility of the text that comes after it; such a legitimation would be probably less important for the Quaker community itself, but it was indispensable in a printed work that was meant to circulate beyond the limits of the religious community it overtly addressed. But Baker's voice is an element of initial mediation, not of constant tutelage: it vanishes as soon as the narrative authored by Evans and Cheevers begins.

Thus $A$ Short Relation begins with a six-page preface by Daniel Baker, "An Epistle to the Readers," which is also printed in the second edition of the text, A True Account of the Great Tryals and Cruel Sufferings (1663); it is followed by a brief "Salutation" by Baker, too, which is considerably pruned in the 1663 edition. The 1662 edition is printed in quarto, while the 1663 edition is in octavo. The account by Evans and Cheevers proper opens with a direct address from the speaking voice to its potential readers, in a gesture which already clarifies, in its use of Scriptural formulae, its religious tenor:

O Ye Eternal and Blessed ones, whose dwelling is on high, in the fulness of all Beauty and Brightness, Glory and everlasting Joy, Happiness and Peace for evermore; We who are poor sufferers for the Seed of God, in the Covenant of Light, Life, and Truth, do dearly salute and embrace you all, according to our measures, Blessing and honour and Glory be given to our Lord God for ever, and all who know him, who hath counted us worthy, and hath chosen us among his faithfull ones, to bear his name and to witness forth his truth, before the high and mighty men of the earth. (Evans and Cheevers 1662:1) 
The speaking voice begins by demarcating the readership it is addressing to: those whose dwelling is "on high," the members of a community (the Quakers) that aims for "everlasting joy," to whom a salute and an embrace are sent, "according to our measures." But this initial gesture is not carried out by one person alone: from the start, the narrative voice speaks in the first-person plural, a " $w e$ " that includes both Katharine Evans and Sarah Cheevers, "poor sufferers for the seed of God." This early reference to themselves as suffering for the "seed" also implies an insistence on their role as preachers, as those who are directly involved in spreading and disseminating the sacred word, in the work of fertilising the earth with the Spirit. After this initial welcoming gesture (in itself typical of Quaker literature), the text immediately acquires a more narrative quality:

The Lord did give us a prosperous journey hither, and when we came to Legorne, we were refreshed with friends [who were there before us] and they did get a passage for us (and lodging) but as soon as we heard of the Vessel, we did feel our service. So we went into the City in the living power of the Lord, and there many tender hearts did visit us, to their comfort, and our joy. The little time we staid there we gave some of our Books and one Paper: so, journeying towards Alexandria, the Captain told us that Malta was in the way, and he must put in there a small time. But, before we came there, our burthen was so heavy, that I was made to cry out (saying): Oh, we have a dreadful cup to drink at that place! (Evans and Cheevers 1662:1)

The missionary activity of the two women starts at Livorno ("Leghorn"), and part of that activity is identified as the distribution of printed material, which will afterwards be the source of their trouble and used as proof against them by the inquisitors. In terms of style, there is a particularly telling moment in this section: as the ship arrives at Malta, Evans' voice differentiates itself, for the first time, from the dominant "we", and there is a first hint of an individual perspective in the text ("I was made to cry out, saying: 'Oh, we shall have a dreadful cup to drink!'”) It is surely no coincidence that this use of the first-person singular pronoun should appear in an anticipation of suffering, nor that it should introduce a reference to Scripture (evoking Christ's own words at Gethsemane, before his Passion). Evans' sense of individual subjectivity is not constructed in a void, but against external opposition; it does not appear as the spontaneous expression of an isolated self, but as a voice that is strongly informed by the accents and the language of Scripture. 
The text goes on to detail how several storms slowed the women's progress towards Malta (as in anticipation of oncoming disasters), and how, upon their arrival, they were received by the English consul, who required from them a complete account of their mission. At this point, of course, the two women do not fail to remember that Saint Paul "suffered shipwrack" on an island: the identification with Paul will also be a recurring feature of their selfdefinition, and a source of consolation in their troubles. These start soon enough; having entered a church adjoining a monastery, they refuse to bow before the altar, a gesture that immediately identifies them as heretics in the eyes of the local community. It is at this point that the Inquisition intervenes:

The inquisitors sent for us, and when we came before them, they asked our Names, and the Names of our Husbands, and the Names of our Fathers and Mothers, and how many children we had, and they asked, wherefore we came into that Countrey? [...] The next day they came again, and called for us, and we came; but they would examine us apart, and called Sarah, and they asked, Whether she was a true Catholick? She said, that she was a true Christian that worshippeth God in Spirit and in truth; and they proffered her the Crucifix, and would have had her sware that she would speak the truth; and she said, she should speak the truth, but she would not swear, for Christ commanded her not to swear, saying, Swear not at all. (Evans and Cheevers 1662:4)

In this passage, it is the voice of Sarah Cheevers that is singularised and set apart: but, since the text is written by Evans, Cheevers' voice is reported externally, with her perspective being distinguished from the dominant one (Evans') through the use of the third-person singular pronoun ("She said that she was a true Christian"). It is also important to observe that, in the 1662 edition, the language of the inquisitors is physically distinguished from that of the two women through the very typography: their voices are reproduced in italics, while the voices of Evans and Cheevers appeared in unmarked roman type. The very external appearance of the text, its material presentation, seems to emphasise the ongoing contrast between the different perspectives, and different worldviews, taking place within it.

The second occasion we hear Evans' individualised voice occurs immediately afterwards, and it is also caused by her being interrogated separately (as Sarah Cheevers was before her) at the 
hands of the inquisitors. The theme of this interrogation is, initially, the worship of the crucifix, though the exchange quickly turns into a debate on the authority of human institutions:

Two dayes later they came again, and called for me, and offered me the Crucifix, and told me that the Magistrate commanded me to Swear by it, that I would speak the truth. And I told them that I would speak the truth, for I was a Witness for God; but I should not swear, for a greater than the Magistrate, saith, Swear not at all, but let your yea be yea, and your nay be nay [...] But said they, You must obey the justice, and he commandeth you to swear. I said, I should obey Justice, but if I should swear, I should do an unjust thing, for (the just) Christ saith, swear not at all. (Evans and Cheevers 1662:45)

The first-person singular pronoun tends to appear in the text when the context forces it to be differentiated from the communal "we"; it is only then that Evans speaks as an individual. And it is especially important to observe that, when she does so, her voice is sustained firmly by Scripture and by the guidance of Christ: it is from these sources that she derives her strength and sense of selfhood, for she is only, in her own words, "a witness for God." It is this role of witness that allows her to speak individually and to defend herself strenuously, and this act of affirmation (that generates an individual perspective) also involves a direct questioning of any external authority: Evans does not swear on the crucifix, because "a greater than the magistrate" commands her not to do so. Thus Evans' individuality is created dialectically in this text, through an open conflict with external forces, while being directly sustained by the voice of Christ as expressed in the Gospels.

Evans speaks in the first person every time she reports her separate interrogation at the hands of the inquisitors, or on the occasions when she reports her personal visions or inner conversations with the Spirit; on all other occasions, her perspective is merged with Cheevers', and expressed in the first person plural. This is what occurs in the third interrogation (this time, on matters of doctrine), when both women are questioned in depth on the specific aspects that differentiate their beliefs from those of the Catholic faith:

He asked, How we did believe the Resurrection? We answered, We did believe that the just and the unjust should arise, according to the Scriptures [...] He asked, if we believed in Purgatory? We said, No; but a Heaven and a Hell [...] He asked, if we believed 
their holy Sacrament? We said, We never read (the Word) Sacrament in Scripture. The Fryar replied, Where we did read in our Bibles Sanctification, it was Sacrament in theirs. He said, Their holy Sacrament was Bread and Wine, which they converted into the Flesh and Blood of Christ by the virtue of Christ. We said, they did work Miracles then, for Christ's virtue is the same as it was when it turned Water into Wine at the Marriage in Canaan. (Evans and Cheevers 1662:6)

This is a key episode, not only in terms of the women's confrontation with their captors, but especially because it sets the dominant pattern of voices and perspectives for the rest of the text. It should be noticed that Evans does not deem it necessary to distinguish between her own voice and Cheevers' when it comes to matters of doctrine (their answers in this text are always introduced by "we said"): it does not matter who actually voices the responses to the inquisitors, or which of the two women is speaking, as long as their doctrinal position is clear: they speak with the same accent. And that accent is in turn distinguished from the inquisitors': their doctrinal positions are also included at every point, and Evans is careful to reproduce their voices at length, so as to preserve a full sense of dramatic exchange, and to specify the doctrinal divergences at stake. ${ }^{5}$ We may have some doubt as to the exact accuracy of Evans's rendering of the inquisitors' voices (they probably did not state that they "converted" bread and wine into flesh and blood, for example), but her wish is to include the language of their adversaries, and to contrast it at every point with their joint perspective. The confrontation reproduced here is a clash of opposing voices, each of them poised against the other and developing over and against it; the typography of the 1662 edition of the text directly enhances this sense of dramatic contrast by presenting the voices of the inquisitor and of the two women in two alternative letter types (italics and roman, respectively), which oppose each other visually on the surface of the page (even the voice of the Spirit is distinguished by being printed in Gothic characters, and thus set apart from the dominant roman lettering: not an innocuous kind of differentiation, of course).

\footnotetext{
5 The question of reproducing the voice in the text is complicated further when we take into consideration the fact that some sentences by Evans and Cheevers throughout the whole text are borrowed directly from The Book of Common Prayer.
} 
Here it is important to pause and reflect for a moment on the canny appropriation and manipulation of the material conditions of textual production and publication in this tract. This text is addressed primarily to the Quaker communities, but it could also circulate beyond them: in any case, the reader first approaching it would necessarily notice the variety of fonts; a subseqent, more careful reading would reveal that, with only a few exceptions, the fonts (gothic, italics, and the dominating roman type) tend to classify and order the many voices of the text. In this way, the very material appearance of $A$ Short Relation becomes a part of its message, and cannot be disentangled from it. We cannot establish with any certainty, of course, where the decisions concerning the use of different fonts originated: whether Evans gave specific indications as to their use, or whether this was established exclusively by Robert Wilson, the printer, or by Baker; in fact, given the degree of closeness and collaboration between Evans and Baker, it is quite possible that the decisions about fonts were agreed on by both of them. In any case, what matters is the adaptation of the possibilities offered by print to the rich, multi-vocal interplay of the narrative: the physical characteristics of print, its stylistic dynamics, are harnessed to the religious impulse that drives the text.

Other voices are occasionally included as the narration proceeds: the voice of the English consul (who attempts to improve the situation of Evans and Cheevers), and those of the judges and the prison-keepers. In this way, the narration of the women's imprisonment integrates within itself a remarkable variety of accents, even though the dynamics of the text tend to reproduce similar patterns of dramatic confrontation, in which the women's language is opposed to that of their captors and the Catholic authorities. An external appearance of heteroglossia is thus created as the text progresses; however, it is unclear to what extent this text is really heteroglot in the Bakhtinian sense of the term.

The intensity of these exchanges increases as time goes by; after the first month of captivity, the women start a period of fasting in order to force their release or, if this should not be possible, to achieve martyrdom. At that point, Evans is once again separated from Cheevers, and a Dominican friar almost uses physical violence against her. The strong tension of the verbal exchanges is centred, in 
this occasion, on the use and significance of the crucifix, which comes close to being used as a weapon:

The Fryar commanded my dear friend to go out of the room, and he came and pulled my hand out of the bed, and said, is the devil so great in you, that you cannot speak? I said, Depart from me thou worker of iniquity, I know thee not; the Power of the Lord is upon me, and thou call'st him Devil. He took the Crucifix to strike me in the mouth, and I said, Look here! and I asked him, whether it were that Cross which crucified Paul to the World, and the World unto him? And he said, it was, I denied and said, the Lord had made me a Witness for himself against all workers of iniquity $\mathrm{He}$ bid me be obedient, and went to strike me: I said, Wilt thou strike me? He said he would. I said, Thou art out of the Apostles Doctrine, they were no strikers; I deny thee to be any of them who went in the Name of the Lord. (Evans and Cheevers 1662:10)

Here the crucifix becomes a sign over which opposing discourses are projected, and it acquires different connotations depending on who interprets and uses it. For Evans, the crucifix is not only a reminder of the passion and of Christ, but, very significantly, the same cross which brought about the crucifixion of Paul: for her, its sight awakens a sense of parallelism between herself and the first Christians, which reinforces her role as a disciple of Christ and a preacher of his doctrine. For the Dominican friar, on the contrary, the crucifix is a sign and guarantee of his own authority, a physical representation of the power of the church, and, as such, it can be used physically against heretics. The moment when the Friar tries to strike Evans for the second time marks the climax of this confrontation, but, even at this point, Evans can turn the tables on her captor, by making use of one of the essential tenets of Quakerism, the renunciation of all forms of violence: the apostles "were no strikers," and none that threaten others can number themselves among "them who went in the name of the Lord."

There is a final element that contributes to the differentiation of Evans' voice, even beyond her constant contact with the Spirit: the visions that she receives individually, in moments of crisis, and which are a major source of relief and comfort in her trouble. These visions occur only in specific moments, coinciding (perhaps intentionally) with periods of fasting, or of great physical deprivation. Fasting was a common form of active resistance for Quakers whenever they were deprived of freedom or put under 
institutional pressure, and Evans and Cheevers make use of it twice during their imprisonment. On the first occasion, after having fasted for several weeks, and having rejected the help of a physician that the inquisitors had sent to them (in exchange for their doctrinal recantation), Evans experiences a long and complex vision, which appears to have been sent to her as comfort in her time of need:

I saw a great wonder in Heaven, the Woman cloathed with the Sun, and she had the Moon under her feet, and a Crown of 12 stars upon her head, and she travelled in pain ready to be delivered of a Man-child, and there was a great Dragon stood ready to devour the man-child as soon as it was born; and there was given to the Woman two Wings of a great Eagle to carry her into the desert, where she should be nourished [...] And I heard another trumpet sounding in Heaven [...] and I heard a voice saying unto me, 积ehold And I looked, and I saw Pharaoh and his host pursuing the children of Israel, and he and his Host were drowned in the Sea. (Evans and Cheevers 1662:12)

This vision is, for the most part, nothing more than a reworking of key passages in chapter 12 of the Book of Revelation; the apocalyptic imagery here evokes the themes of persecution by the devil (through the key image of the woman crowned with stars and menaced by the dragon) and of confrontation between good and evil (in the final battle between angels and demons, at the end of time). To be sure, there is an implicit typological identification here: Evans and Cheevers are also living under persecution, and even in their imprisonment they are contributing to the arrival of the Final Judgement by participating in the war against the forces of evil. There is a further use of typology at the end of the passage, when Evans hears the trumpets that announce the drowning of Pharaoh and its hosts; here both women are implicitly identified with the people of Israel in their exile. Evans' visions are outstanding for their lack of sensory or physical detail; there is little in them that can be compared to the strong sensory quality we find in the writings of Catholic mystics, for example. On the contrary, the very substance of these visions is the text of Scripture, the word of God, remembered and re-experienced by the speaker in ways that establish implicit parallelisms between herself and the biblical figures and situations that she evokes. Interestingly, Evans herself is keenly alert to the textual basis of her visions; immediately after the passage quoted above she hastens to certify its authenticity, despite its evident dependence on the text of the Bible: 
Dear Friends and People, whatsoever I have written, it is not because it is recorded in the Scripture, or that I have heard of such things, but in obedience to the Lord I have written the things which I did hear, see, tasted and handled for the good Word of God, in praise of his Name for ever. (Evans and Cheevers 1662:1213)

In this way, the very language of Scripture is explicitly recognised by Evans herself as a key constituent of her own voice, and as informing and determining key areas of her perspective and identity. The word of God, then, is to be distinguished and privileged among all the other words that are heard in the text; it thus begins to be evident that the multi-vocality of the text does not open itself to a full heteroglossia, but rather relies on one single voice, that of the Lord (expressed either through Scripture or through the Spirit), as its ultimate source of authority and truth.

At this point, it should be possible to clarify the relationships that are established among the various voices speaking in the text, and to determine the hierarchies among them. In order to do so, I will analyse the multi-vocality of the narrative with the help of a representative section in its second half, at a key moment: the description of the second period of fasting voluntarily undergone by the two women. This situation occurs after several unsuccessful attempts at mediation by the English consul, and after the help of a physician has once again been rejected by the two women, whose physical decay is beginning to be evident to all. It is at that point that their fasting begins:

Then the Lord called us to fasting for eleven dayes together, but it was so little, that the Fryars came and said, that it was impossible that Creatures could live with so little meat, as they did see we did for so long time together; and asked what we would do? And said their Lord Inquisitor said, We might have anything we would. We said, We must wait to know the mind of God, what he would have us to do. We did not fast in our own Wills but in obedience to the Lord. They were much troubled, and sent us meat, and said the English Consul sent it. We could not take any thing till the Lord's time was come. We were weak, so that Sarah did dress her head as she would lye in her Grave, (poor Lamb) I lay looking for the Lord to put an end to the sad trial which way it seemed good in his sight. Then I heard a voice, saying, 嫼 shall not oye. [...] Our Enemies treated us kindly in a strange Land, said I. But we were afraid to eat, and cryed to the Lord, and said, We had rather dye, 
than eat any thing that is polluted and unclean. The Lord said unto me, Thou mayest as freely eat [...] Yet the Lord did work as great a Miracle by our preservation, as he did by raising Lazarus out of the Grave. [...] The Fryars did say, the Lord did keep us alive by his mighty power, because we should be Catholicks. We said, the Lord would make it manifest to us then; they should know the Lord had another end in it one day. (Evans and Cheevers 1662:2324)

The dominant perspective here is presented, as usual, as a shared one ("the Lord called us to fasting us for eleven dayes"); against this voice appear those of the Inquisitors, italicised, so as to be clearly demarcated, and presented in debate with the voices of the two women, and as opposed to them. There are a few moments when we notice that Evans' own voice is more clearly individualised: first, when she notices Sarah's preparation for death ("Sarah did dress her head as she would lye in her Grave, poor Lamb") and, second, in her direct exchanges with the voice of God, which speaks directly to her, and thus singularises her ("Then I heard a voice, saying, Ye shall not die"). After some food is offered to the women by their captors, a quote from the Psalms is introduced ("Our enemies treated us kindly in a strange land"): Scripture is thus woven into the text, and used as a perspective from which the situation can be interpreted. Biblical typology is also present in situational parallels with the beginnings of Christianity, so as to assert the direct intervention of God ("the Lord did work as great a miracle for our preservation, as he did by raising Lazarus from the grave"). In the end, the whole situation is only resolved when the voice of the Spirit authorises them to eat, through direct communication with Evans ("the Lord said unto me, Thou mayest as freely eat"). And even at that moment, after they have been saved and their fasting has ended, the situation is interpreted in contradictory ways by them and by the inquisitors; both interpretations are included, and contrasted with each other, at the end of the paragraph.

This episode can be taken as a telling example of the way in which the whole narrative works: as a story told by different voices presented in active interaction, but which do not have the same authority in the text. All of the voices are included and reproduced within the dominant, shared perspective of the authors, but the interpretative acts within the text, the occasions on which the 
situation is evaluated, tend to occur in the individualised voice of Evans when she hears the Lord speaking to her; and on these occasions it becomes evident that her own voice is entirely subordinated to that transcendent, superior authority. In this way, the whole variety of the voices in the text is subordinated to one single voice: that of the Spirit, which determines the actions of the women and validates their experience. That voice is in turn complemented by the various quotations from Scripture, which may be voiced by the Spirit or evoked by Evans, or which, alternatively, may be echoed in her visions.

Thus, a text that initially seems to offer a multiplicity of perspectives and a fluent multi-vocality reveals itself, in the final analysis, to be structured according to an underlying single purpose and unified perspective. Since $A$ Short Relation does not contain a variety of points of view on an equal basis, but offers one dominant viewpoint (Katharine Evans') and ultimately one basis of interpretation (furnished by the voice of the Spirit), and since the text does not display a real variety of styles coexisting equally in the same space, but a subordination of all these styles to the voice of God, it is safe to conclude that the text displays a vivid formal plurality, but one which does not open itself to a full heteroglossia. On the contrary: while its surface seems to offer a continuous exchange and interplay between different voices, a close stylistic analysis shows that this is only an appearance; it is the voice of the Spirit, speaking in the accents of Scripture, that is offered as the ultimate truth in the text, and as the ultimate basis for any interpretation of it.

\section{Gendering the Text: an Impossible Task?}

Some key elements of the early Quaker faith coincided with themes that had become popular in the radical agenda within the context of the English Civil War: Republicanism, communality and freedom of conscience. This latter aspect manifested itself in Quakerism as a complete lack of external religious authority, since spirituality was experienced there through personal contact with God (the "Inner Light"). Elaine Hobby has argued that "by the Revolutionary years, arguments used to justify intervention in public affairs by those men previously excluded from politics proved 
particularly adaptable to support the idea that women, too, could act" (2002:162); therefore, a large number of women could make the most of this opportunity to gain self-esteem and presence in the public arena. Still, readers in the twenty-first century are left wondering to what extent Evans and Cheevers (and, indeed, most women prophets from the period) were fully sensitive to gender issues, if at all. In this regard, Phyllis Mack reminds us that "a primary tenet of early Quakerism was that the hierarchical character of gender relationships, indeed of all social relationships, was a product of human sinfulness, an outcome of the original Fall from grace" (Mack 1992:140). We must therefore be ready to acknowledge the religious purpose behind the Quaker attempt at reaching for equality and communality and obliterating any sign of social status, including gender.

The new kind of freedom offered by Quakerism must have been attractive for many women, but not necessarily because of reasons directly related to their gendered identity. In their narration of captivity in Malta Evans and Cheevers can oppose Catholic authorities in a very powerful and convincing way, and even engage in direct communication with God: this empowers their faith and their authority, but seems to affect their condition as women only indirectly. Danielle Clarke invites us to distinguish between material conditions (in this case, the opening of new possibilities for women within radical and dissenter groups) and their effect upon the texture of a piece of writing; according to her, we cannot automatically appropriate those texts to serve the interests of feminism:

One might argue that in relation to the Renaissance, this needs to be taken a step further still: not only are most of the texts in question not feminist in any legible sense, they are also subject to a series of conditions and regulations which we do not always recognize. If these texts refuse to yield up feminism, it may also be the case that feminism, as it has been applied, does not yield up the texts. (Clarke 2000:7)

But even if we cannot read $A$ Short Relation with a feminist agenda in mind, it is still possible to examine it in detail to see what kind of gender discourse is articulated within it. For example, gender concerns seem to be only secondary during the first confrontations between the two women and the inquisitors. Being women, of course, they are first made to identify themselves in terms of the 
families to which they belonged ("they asked us our names, and the names of our husbands"), but the interrogations quickly come to be focused on matters of doctrine, and other aspects are temporarily forgotten. It is only after the two women make use of active forms of resistance (such as fasting) that the accusations and reactions against them begin to show signs of misogyny; in the second half of the narrative, Evans is called a "madwoman", a "possessed one" and, eventually, a "witch" (twice). None of these terms, however, awaken any strong response from her (as we have seen, she only reacts energetically when matters of faith are at stake). There are occasional hints of a more purposeful gender differentiation when an apparently friendly Dominican friar tries to persuade the women to convert, and starts addressing them as "good women;" in contrast, and unsurprisingly, Evans immediately hears the voice of God designating herself and Cheevers as "daughters of Sion:"

He then did say, We were good Women, but yet there was no redemption for us, except if we would be Catholicks. Now the Lord said, Fear not, Daughters of Sion, I will carry you forth as Gold tryed out of the fire. And many precious promises did the Lord refresh us with, in our greatest extremity [...] And the Lord said, fear not Daughter of Sion, ask what thou wilt, and I will grant it thee. (Evans and Cheevers 1662:34)

In itself, this does not go beyond an act of re-naming, through which Evans can cast herself and Cheevers into a more heroic role than that simply of "good women." Later on, when several attempts are made to force Evans to convert to Catholicism, she thinks her enemies are trying to lead her to a renunciation of her beliefs by treating her more courteously:

I cannot expresse the large love of our God, how he did preserve us from so many deaths and threatenings, as they did come to me with falling upon their knees, saying Miss, and would have me to say after them, but in the Name of the Lord I denied them. (Evans and Cheevers 1662:37)

On another occasion, one of the friars tries to force Evans to perform some kind of practical work to occupy her time in prison; Evans states that she is quite capable of writing, and at that point it becomes evident that Quaker culture has trained her in forms of intellectual activity (in the service of faith) that do not fit Catholic perceptions of women's work. After this exchange, Evans' capacity for work is redirected towards more traditionally feminine 
occupations, and both she and Cheevers end up repairing the clothes of other prisoners:

The Fryar then came to me, and askt me, why I did not work? I said unto him, What Work dost thou do? He said he did write. I told him I would write too, if he would bring me a Pen, Ink and Paper, and I would write truth. He said, He would not that we should write, for St. Paul did work at Rome, and we might get nine or ten grains a day, if we would knit, that is three half pence [...] Then his mouth was stopped, and he spake no more to me of work: But though our affliction of body was great, and our travel of soul was greater, yet we did knit Stockins, and gave to them that were made serviceable to $u$., and did make Garments for the poor prisoners, and mended their Clothes which had need, and were made helpful to them all. (Evans and Cheevers 1662:41-42)

In this way, in the Maltese prison, and under the supervision of Catholic authorities, two women who are used to reading and writing have to turn to more conventional forms of work. The absence throughout the text of any sense of female inferiority is remarkable. In the seventeenth century, dominant religious ideology (whether protestant or Catholic) established a solid identification between woman and sin, and tended to see the very image of woman as symbolising the flesh, temptation or sinfulness. These connotations are conspicuously absent from the writings of Evans and Cheevers: at no point do they seem to have any perception of negative connotations of their gender, not even at a symbolic or figurative level. Their use of biblical language tends, if anything, to reinforce this impression. The religious figures they compare themselves with are the apostles, the first Christians (most notably St. Paul), Old Testament patriarchs and prophets (Daniel, David, and Jonah) or Christ himself: the typological referents involved in the text are almost uniformly male, and the women see these referents as valid elements of self-identification. There are almost no typological identifications with female figures (a notable exception being the image of the woman crowned with stars, in Evans' vision); the two women see themselves as empowered prophets and preachers, as fully authorised as the ancient patriarchs, irrespective of their condition as women.

The personal letters Daniel Baker added to A Short Relation in the second printing of the narrative in 1663 are relevant here. Although we might be tempted to suspect some modification of 
these texts by Baker, it is unlikely that this actually happened: in early Quakerism, epistle writing was very often used to strengthen the bonds among Friends living in distant communities. Letters written and sent from one Quaker community to another could therefore come to perform a double function, as private documents (from one family member to another) and as public texts (meant to be read in public, as examples of perseverance and endurance, and as having doctrinal content). In this context, letters written by women could easily become a textual space for freedom: according to Margaret Ezell, women could find in letters a space "through which to express their anger at the wrongs suffered at the hands of contemporary society and their loyalty to the beleaguered flock" (Ezell 1993:142). For example, we find the voice of Katharine Evans, addressing herself to her husband and children, in a letter written "in the Inquisition in Malta, in the eleventh month of the year 1661:"

Most dear and faithful Husband, Friend and Brother, begotten of my Eternal Father, of the immortal Seed of the Covenant of Light, Life and Blessedness, I have unity and fellowship with thee day and night, to my great refreshment and continual comfort, praises, praises be given to our God for evermore, who hath joined us together in that which neither Sea nor Land can separate or divide. (Evans 1662:53)

Evans' husband is for her also a "Friend and Brother," a member of the same religious community to which she belongs and, to the extent that he is also "begotten of my eternal Father," her equal. This initial address involves references to their union despite their present physical division by "sea or land," but it is in the following paragraph that this subject is fully discussed:

My dear heart, my soul doth dearly salute thee, with my dear and precious Children, which are dear and precious in the Light of the Lord, to thy endless joys, and my everlasting comfort, glory be to our Lord God eternally, who hath called you with a holy Calling, and hath caused his Beauty to shine upon you [...] My dear hearts, the promises of the Lord are large, and are all Yea and Amen to those that fear his Name; he will comfort the mourners in Sion, and will cause the heavy-hearted in Jerusalem to rejoice, because of the glad tidings [...] In our deepest affliction, when I looked for every breath to be the last, I could not wish that I had not come over Seas, because I knew it was my Eternal Father's Will to prove me. (Evans 1662:53) 
Evans salutes her husband and remembers her children, but above all she reminds him of the "calling", that is, the religious mission that has been imposed on him as well as on her. The references to her difficult position at the hands of the Inquisition are introduced by typological references to the sufferings of Israel; and, when her serious plight in Malta is finally discussed ("our deepest affliction"), there is no hint of any desire to return home before completing the mission, or to substitute the pains of prison for the life of a housewife: on the contrary, the pain that Evans experiences in her imprisonment is to be celebrated as signifying "my eternal Father's will to prove me."

A second letter by Katharine Evans is even more explicit. After saluting her husband, somewhat more directly than on the previous occasion ("Dear husband, with my dear children, I beseech you together to wait in patience"), Evans goes on to express her longing for her family:

I have been very sensible, dear Husband of thine, and our Children, and many dear friends more, of your sorrowful souls, mourning hearts, grieved spirits, troubled minds for us, as being Members of one body, Christ Jesus being our Head, we must needs suffer together, that we may rejoice together [...] Though we are absent in body in the Will of God, from you, yet we are present in Spirit in the Will of God, with you, and we do receive the benefit of all your prayers daily, and do feel the Springs of Life that do stream from all the faithful hearted, to our great refreshment and strengthening. (Evans 1662:61)

There is a clearer sense of longing and of anticipation of a family reunion here; language has become more affective and more expressive of closer personal bonds. Evans' husband and children, however, are regarded as part of a wider community ("many friends more"), within which the family is firmly rooted. Both husband and children are evoked as part of an identity that is solidly fixed in the heart of a living and active social network, with Christ himself the head, and within which the work of preaching (and the need to suffer) are seen as essential aspects of self-definition. For Evans, as for so many other Quaker women, being a mother or a wife is not perceived as being in contradiction to that of a preacher (or, eventually, a martyr): on the contrary, her family has to accept her separation from them as part of the service to God that binds them together. Evans' active role in the world and her sense of her own 
worth are legitimised by her social environment, and created within it: Quaker doctrine, and Quaker society, have enabled her to see her mission and activities as being as valid as a man's.

It seems safe to conclude, then, that the absence of a negative sense of the feminine in A Short Relation is, to some extent, the result of the authors' socialization in a community that prided itself on notions of equality. It may seem paradoxical from a twenty-first century perspective, but the strength and confidence with which these women carried out their preaching mission were not opposed to, but based on, their role as wives and members of a strongly selfconscious social group. Evans and Cheevers were able to move beyond the limitations of gender distinction not by overcoming these differences, but simply by ignoring them: an attitude that was firmly rooted in their immediate social milieu.

\section{Conclusions}

There is now a solid scholarly consensus ${ }^{6}$ that the corpus of early Quaker women's writing can help us to trace the beginnings of female voices in literature, as well as early notions of female selfhood. Quaker women belonged to a community that empowered them spiritually, and within that community they formed a subgroup which, because of their religious commitment, could go beyond traditional definitions of gender identity. According to Elaine Hobby, "what is evident from this sample of visionary prophets is both that the role of prophet could give a woman access to an audience for her views, and that the question of her gender was always an issue for those who received her message" (Hobby 2002:269). In A Short Relation we see how Evans' and Cheevers' beliefs empower them spiritually, and how their communication with the Spirit allows a powerful first person singular (and a first person plural) to materialise, opposing voices of male authority.

A Short Relation offers a vivid, dynamic interplay between different voices; it reproduces and integrates contradictory approaches to reality and to religious doctrine. However, as we have seen, close analysis reveals that this seeming variety does not imply an open or (in Bakhtinian terms) a polyphonic perspective: what we

${ }^{6}$ See footnote 5 , above. 
have here is multi-vocality, but not heteroglossia. It is above all the voice of the Spirit that is asserted and recognised in this text, and it is that voice which is presented (both thematically and typographically) as having a pre-eminent authority over all the others. The identity of Katharine Evans is created dynamically in the text, and it is clearly differentiated from that of Sarah Cheevers, in two ways: first, through the constant dialectic exchange between Katherine's voice and those of the male authorities that she opposes, and secondly, through her personal, close interaction with the voice of the Spirit. Identity is thus created here both through a submission and a defence of a religious position and through an intimate sense of exchange with the voice of God, which in the text is presented as speaking to Evans in the accents of the Bible. It becomes evident that their imperviousness to misogyny does not come from a genderconscious attitude but from their religious convictions, which, for them, supersede all forms of institutional or legal constraint. Therefore, A Short Relation and its idiosyncratic interplay of voices creates an identity which goes beyond gender effacement or plain submission to God. This Quaker emphasis on engaging in communication with God, on being one with Him "in the Light" (as Quaker terminology put it), is, however, complemented by various other perspectives and approaches in A Short Relation. The voices and accents of the inquisition and the Catholic authorities are also fully acknowledged and integrated in the text, and they are contrasted at every point with those of the protagonists; even the voice of the Spirit is heard in the text, offering guidance and support to the two women. They echo God's concerns with the contemporary state of affairs and they display rhetorical skills which go beyond the written and the uttered word to be re-enacted in public. When poststructuralist scholars like Christina Berg and Philippa Berry focus almost exclusively on the rhetorical strategies employed by prophetesses, considering that they "represented their own sexuality within a discursive medium where an explicitly political content was subsumed within a highly personalized mode of expression" (Berg and Berry 1981:38), they recognize that the rhetorical power of prophetic speech in the seventeenth century went beyond the content of the words themselves and that it was the interaction between the Biblical message and its various appropriations by female prophets that transformed prophetic writing into a rich locus of study. 


\section{References}

Bakhtin, Mikhail 2006 (1981). "From the Prehistory of Novelistic Discourse." Ed. Michael Holquist. The Dialogic Imagination, Four Essays. Austin: University of Texas Press: 40-81.

Berg, Christina and Phillipa Berry 1981. "Spiritual Whoredom: An Essay on Female Prophets in the Seventeenth Century." Ed. Francis Baker. 1642: Literature and Power in the Seventeenth Century. Colchester: University of Essex Press: 39-54.

Besse, Joseph and Michael Gandy eds. 2003. Sufferings of Early Quakers: Ireland, Scotland and Wales Including Monmouthshire and Shropshire 16531691 Vol 5. London, Sessions Book Trust (facsimile edition).

Biddle, Hester 1660. A Warning from the Lord God. London: Robert Wilson.

Clarke, Danielle 2000. "Introduction." Eds. Danielle Clarke and Elizabeth Clarke. 'This Double Voice': Gendered Writing in Early Modern England. London: Macmillan Press: 1-15.

Coles, Kimberly Anne 2008. Religion, Reform, and Women's Writing in Early Modern England. London: Cambridge University Press.

Crawford, Patricia 1993. Women and Religion in England 1500-1720. London: Routledge.

Evans, Katharine and Sarah Cheevers 2001 (1662). This is a Short Relation of some of the Cruel Sufferings (for the Truths Sake) of Katharine Evans E Sarah Cheevers in the Inquisition in the Isle of Malta. London: Robert Wilson. Facsimile edition: The Early Modern Englishwoman: A Facsimile Library of Essential Works. Eds. Betty S. Travitsky and Patrick Cullen Series II, Printed Writings, 1641-1700: Part I, Vol. I, Life Writings I. Aldershot: Ashgate.

Evans, Katharine and Sarah Cheevers (1663). A True Account of the Sufferings of Katherine Evans and Sarah Cheevers. (London: Robert Wilson). Facsimile edition in Early English Books Online http://eebo.chadwyck.com/home. Copy from Haveford College Library, wing 2220:03).

Fell, Margaret 1660. A Declaration and an Information from us the People of God Called Quakers. London: Thos. Simmons \& Robt. Wilson.

Feroli, Teresa 2006. Political Speaking Justified: Women Prophets and the English Revolution. Newark: University of Delaware Press.

Gill, Catie 2005. Women in the Seventeenth-century Quaker Community: A Literary Study of Political Identities, 1650-1700. London: Ashgate Publishers.

Gill, Catie 2009. "Evans and Cheevers's A Short Relation in Context: Flesh, Spirit, and Authority in Quaker Prison Writings, 1650-1662." Huntington Library Quarterly 72/2: 257-272. 
Graham, Elspeth 1989. Her Own Life: Autobiographical Writings by SeventeenthCentury Englishwomen. Eds. Hilary Hinds, Elaine Hobby, and Helen Wilcox. London: Routledge.

Gillespie, Katharine 2004. Domesticity and Dissent in the Seventeenth Century: English Women's Writing and the Public Sphere. Cambridge: Cambridge University Press.

Gray, Catharine 2007. Women Writers and Public Debate in $17^{\text {th }}$-Century Britain. New York: Palgrave.

Hinds, Hilary 1996. God's Englishwomen: Seventeenth-century Radical Sectarian Writing and Feminist Criticism. Manchester: Manchester University Press.

Hobby, Elaine 2002. "Prophecy." Ed. A. Pacheco. A Companion to Early Modern Women's Writing. Oxford: Blackwell Publishers: 264-282.

Holquist, Michael 2005. Dialogism. London: Routledge.

Knott, John Ray 1993. Discourses of martyrdom in English literature, 1563-1694. Cambridge: Cambridge University Press.

Longfellow, Erica 2004. Women and Religious Writing in Early Modern England. London: Cambridge University Press.

Malcomson, Cristina and Miholo Suzuki 2002. Debating Gender in Early Modern England 1500-1700. New York: Palgrave.

Mack, Phyllis 1992. Visionary Women: Ecstatic Prophecy in Seventeenth-Century England. California: University of California Press.

Punshon, John 2006 (1984). Portrait in Grey: a Short History of the Quakers. London: Quaker Books.

Purkiss, Diane 1992. "Producing the Voice, Consuming the Body: Women Prophets of the Seventeenth Century." Eds. Isobel Grundy and Susan Wiseman. Women, Writing, History 1640-1740. London: Batsford: 139-158.

Trill, Suzanne, Kate Chedgzov, and Melanie Osborne, eds. 1997. Lay by your Needles, Ladies, Take the Pen: Writing Women in England 1500-1700. New York: Hodder Arnold.

Wiseman, Susan 1992. "Unsilent instruments and the devil's cushions: authority in seventeenth-century women's prophetic discourse." Ed. Isobel Armstrong. New Feminist Discourses. London: Routledge: 176-196.

How to cite this article:

Font Paz, Carme. "II have written the things which I did hear, see, tasted and handled': Selfhood and Voice in Katherine Evans' and Sarah Cheevers' A Short Relation of Their Sufferings (1662)." SEDERI 20 (2010): 27-56.

Author's contact: Carme.Font@uab.cat

Submission: 31/10/2009

Acceptance: 21/02/2010 


\title{
Baubles on the Water: Sea Travel in Shakespeare's Time*
}

\author{
Andrew Gurr \\ University of Reading
}

\begin{abstract}
The technical features of travel by water, on sea and up rivers, are not registered as strongly as it should be in studies of the Shakespearean period. In his great edition of The Spanish Tragedy Philip Edwards mocked the author's assumption that the Portuguese Viceroy would have travelled to Spain by sea rather than overland, since the play also notes that the two countries have contiguous boundaries. He did not know how tortuous travel overland from Badajoz to Lisbon could be. A similar ignorance of the routine use of travel by boat around the coast of England and up its main rivers is evident in the studies of playing company travels in the many Records of Early English Drama. Its editors take too little notice of the likelihood that the professional playing companies used London's shipping to carry their personnel and properties on their journeys round the country. The official records of the Privy Council and other state papers show how important access by river was for all bulk transport through England's rivers. Shakespeare could well have travelled from London home to Stratford upon Avon by water. John Taylor the Water Poet wrote several verses about his own travels from London by water that amply demonstrate the ease and the familiarity to travellers of going anywhere by sea and river. But it was never an easy business. Shakespeare himself twice used the word "bauble" or "bubble" in different plays to describe the fragile nature of the vessels used for sea travel.
\end{abstract}

KEYWORDS: Shakespeare, Kyd, water, sea, REED, Taylor.

\footnotetext{
* The core of this paper was prepared as a plenary lecture for the 2010 conference of SEDERI at Porto in Portugal, in April 2010. The conference's title was Ports, and Piers and Roads: Self and World in Early Modern Culture.
} 
Shakespeare's familiar use of sea-images, his exploitation of mariners' language in places like the opening scene of The Tempest, provoked some scholars in the last century to speculate that he was so familiar with seamen's terms that he must have been a shipman, or at least a voyager far beyond the shores of England. I think that unlikely, but I do believe that he had ample experience of travelling by water. Such an idea is hardly surprising, considering that he worked in London, the country's biggest port, that for fourteen years he owned part of a theatre built alongside the river Thames, and that the simplest if not the quickest form of transport between London and his home in Stratford upon Avon was by river rather than on horseback. We need to watch out for travel by water everywhere in these early texts.

In his magisterial Revels edition of The Spanish Tragedy, Philip Edwards noted in a footnote to line 11 in Act 3 scene 14 that the Spanish King's welcome to the Portuguese Viceroy, when he says he had "crossed the seas" to reach Spain, must be what he called "an amusing howler" on Kyd's part (1959:91). Edwards pointed out that at 1.2.22 the Spanish General had made the comment that "Spain and Portingale do jointly knit / Their Frontiers," and concluded that overland travel was the obvious form of access for the Portuguese to get to Spain. The idea that the Viceroy might have chosen to go by ship from Lisbon to Spain did not occur to Edwards, nor for that matter to any other of the play's editors and critics over the centuries. But I think that Kyd, like Shakespeare, knew far more about travel in those days than did any of their critics.

In June 1580, when following the disaster to the Portuguese court of the Battle of Alcázar in Morocco Phillip II decided to take over the crown of Portugal, the Duke of Alba's army took a long time to get from Badajoz on the Spanish border to Lisbon, simply because the roads were so appallingly bad, even for horses. Travel round the coast by sea was the standard means of access for large parties, especially royalty. Alba rode on horseback with his army of 40,00o pedestrians through Elvas, Borba, Estremoz, Vimeiro and Montemor, and then on to a rendezvous with a fleet sent by sea at Setubal. One of his main aims on this last of Alba's many great military expeditions was to control his troops firmly enough so that they would not alienate the population of the areas they were 
marching through. For this purpose he equipped them with all the necessary provisions, so that they would not pillage the now allegedly Spanish countryside. Badajoz, where he started from, was a small town in a largely barren region, so he had to gather his provisions from far and wide, levying them all the way from Andalusia to as far as Ibiza -in fact he gathered so much he was able to sell a lot off to the ecstatic locals in Llerena and Badajoz. His equipment for this journey was much what a royal court would have travelled with overland.

His engineer, Gian Battista Antonelli, however, gave him ominous reports about the state of the roads, and when they set out in June his army was mostly foot-soldiers, accompanied by 136 large cannon and food and baggage hauled in an endless line of oxcarts. It was a dreadfully bad journey, taking nearly a month to cover 170 kilometers. In the dry areas of the Alentejo water was in dreadfully short supply, and a plague of influenza was ravaging the local populations. The road was so bad that Alba reported the oxcarts kept breaking down, "as if they were made of twigs." "Since I was born," he added, "I have never seen country so rough. The road has ruts so broad and so deep and so hard they seem to be frozen like at Christmas." ${ }^{1}$ You can see why it would have been entirely routine for the Portuguese Viceroy in Kyd's play to journey to the Spanish court by sea rather than by land. When Alba, after all the troubles and losses of this long journey finally confronted the Portuguese enemy under Don Antonio on the outskirts of Lisbon, his professional expertise easily outflanked them in the battle of 25 August 1580. The aftermath of that battle was the occasion when the story told in Kyd's celebrated play begins.

In this context we might wish to register the implications of what a friend and schoolmate of Kyd's, Thomas Lodge, wrote in 1590. Lodge is known to us chiefly as a playwright and poet, author of Rosalynde, source for Shakespeare's As You Like It. But in his epistle to "the Gentlemen Readers" he described himself as not a poet but "a souldier, and a sailer, that gives you the fruits of his labors that he wrought in the Ocean, when everie line was wet with a surge, \& everie humorous passion countercheckt with a storme." In 1585 Lodge had sailed to the Azores as part of the English and French

\footnotetext{
${ }^{1}$ My account of this trek is taken from Maltby (1983).
} 
attempts to sustain Don Antonio as the Portuguese Pretender against the Spanish, an expedition from which his friend Kyd must have learned a lot for The Spanish Tragedy. Rosalynde's dedication to Henry Carey, Lord Chamberlain, soon to be patron of the Shakespeare company, specifies that it came about while making "a voyage to the Islands of Terceras \& the Canaries, to beguile the time with labour, I writ this book; rough, as hatcht in the stormes of the Ocean, and feathered in the surges of many perillous seas" (Lodge 1590:A2V,A4). Later in 1590 Lodge joined the second Cavendish expedition to sail round the world. His first expedition lasted from 1586 till 1588, and I shall shortly quote something from it. Londoners were familiar with multitudes of ocean-going ships on their riverbanks, and many citizens travelled in them. Even those who did not sail off knew what the seafarers' gossip was. It is a minor but distinctive feature of Marlowe's 2 Tamburlaine that he should have his hero propose to cut a version of what later became the Suez Canal between the Mediterranean and the Red Sea. The knowledge that voyagers like Lodge took from their travels spread easily amongst their landbound friends and contacts.

I will quote from Cavendish's own summary account of his first voyage in his dedicatory letter to Henry Carey, which appeared in Hakluyt in 1589, chiefly because it says a lot about the main issue that stimulated the writing of Kyd's play about the Spanish takeover of the Portuguese crown. In his preliminary remarks Cavendish wrote

It hath pleased the Almightie to suffer me to circumpasse the whole Globe of the world, entring in at the streight of Magelan, and returning by the cape Bona Sperança. In which voyage I have either discovered or brought certeine intelligence of al the rich places of the world that ever were knowne or discovered by any Christian. I navigated alongst the coast of Chili, Peru, and Nova Spagna [Mexico], where I made great spoyles: I burnt and sunke 19. sayles of shippes small and great. All the villages and townes that ever I landed at, I burnt and spoyled: And had I not bene discovered upon the coast, I had taken great quantitie of treasure. The matter of most profit unto me was a great ship of the Kings [of Spain] which I tooke at California, which ship came from the Philippinas, being one of the richest of Marchandise, that ever passed those Seas, as the kings Register and Marchants accompts did shew, for it did amount in value to * [Hakluyt left the amount to be filled in later] in Mexico to be sold: which goods (for that my 
shippes were not able to contayne the least part of them,) I was inforced to set on fire. From the Cape of California, being the uttermost part of all Nova Hispania, I navigated to the Ilandes of Philippinas hard upon the coast of China, of which Countrie I have brought such Intelligence as hath not bene heard of in these parts. The statelines and riches of which countrie I feare to make report of, least I should not be credited. For if I had not knowne sufficiently the incomparable welth of that countrey, I should have ben as incredulous thereof, as others will be that have not had the like experience. I sayled along the Islands of Maluccas, where among some of the heathen people I was well intreated, where our country men may have trade as well as the Portingals, if they will themselves. From thence I passed by the cape of Bona Sperança, and found out by the way homeward the Iland of Saint Helena, where the Portingals use to releeve themselves: And from that Iland God hath suffred me to returne into England. ${ }^{2}$ (Hakluyt 1589:Dddd2)

What he could not capture, he had broken and ruined. This account on its own would be enough to explain why the Spanish were so concerned to uphold Pope Alexander VI's famous diktat of 1493 about the division of the world outside Europe between the seapowers of Spain and Portugal, especially once Portugal became a part of Spain in 1580. The now omnivorous world power of the Iberian peninsula had to fight to keep the anti-Catholic English and Dutch explorers out of it all.

Cavendish's outlook and his account of his voyage provides the fullest possible context for Kyd's play, which is set at the takeover of Portugal by Spain. The riches to be got from sailing across the Atlantic were the most fundamental motivation for all the politics and wars of that period. Protestant opposition to Spain in Holland and England and above all on the high seas always had the desire for money behind it. Kyd and Lodge and everyone in London knew that at first hand, just as they knew the point of travelling between Spain and Portugal by ship rather than going overland.

At a far more banal level, a similar problem to that which made the critics of The Spanish Tragedy assume that travel between Spain

\footnotetext{
${ }^{2}$ The passage is also quoted (in modernized spelling) by, of all people, Philip Edwards 1988:51). Edwards also has a book, Sea-Mark. The Metaphorical Voyage, Spenser to Milton (1997) in which he examines references to the sea in three plays by Marlowe and eight by Shakespeare.
} 
and Portugal must have been by land, exists with the editors of the Records of Early English Drama. We know that the touring companies in England used carts and horses to go by road from one town or country house to another, but almost none of the current REED editors has taken any notice of the fact that many of the towns the companies visited were sea ports. The great likelihood is that from the port of London they travelled to them by water, not by land. Far more ports were in use then than we have any idea of now. Elizabethan bureaucracy has left us some records, especially in the early 1590s, when the Privy Council was hotly pursuing the many secret landings of Jesuits and other recusants from France or Spain anywhere on the southern English coast and its many fishing villages, but sadly these records do not give us direct information of the kind that the REED editors need. Under Elizabeth a series of Port Books (National Archives E190) were issued in 1564. These were folio-sized volumes, sent to every major port which did any sort of trade, either coastal or overseas. The object was to get its local authorities to record whatever trade their and their neighbouring ports were engaged in. They were expected to make annual returns in those giant folios, registering the variety and the cost of each traded item. In the nature of bureaucracy, individual ports provided their own different ways of answering this demand, but the many surviving books do give us the best record we have of the great mass of trading activities conducted around England's coasts from the year 1564 onwards. Sadly for our purposes, they do not provide any evidence of human trade, the names or the kinds of people such as the acting companies who might choose to travel by water to any of the towns accessible round the coast.

The Port Books do reveal what an amazing variety of towns and villages there were engaged in sea trade in this period. Many of them were settlements that today we would not expect to have ever had any sea-going interests. The central Exchequer regulation of 1564 required small parishes along the coast to have their records grouped together at one central and adjacent port which was made responsible for recording the returns in the great folios. Newcastle upon Tyne, for instance, included records from more than twenty different parishes along the adjacent coastline, besides the substantial ports of Whitby (E190, 185/3), Hartlepool (E190, 185/2) and some other mainly fishing settlements. Chester as one of the official recipients of a Port Book had to include all the parishes along 
the north Welsh coastline, plus Liverpool and other areas in Lancashire. The major towns with coastal or river access to the sea who were required to make these multivalent returns included, besides Newcastle and Chester, York, Ipswich, King's Lynn, Dover and its many adjacent towns such as Folkestone, Hyde and Rye, Southampton, Exeter, Barnstaple, Plymouth, Falmer, Bridgwater, Bristol, Gloucester, Milford, and Carlisle. London itself, easily England's biggest port, made regular returns, chiefly over sales of wool and leather, though a multitude of other goods occasionally make an appearance in those great folios.

It would have been easy for any of the London playing companies to have used coastal shipping for their travels, conceivably even hiring the one boat to carry them all the way round the coast from port to port. The sea gave them quick and simple transport to many towns easy of access. Given the loads of expensive costumes and properties they had to carry with them for their plays, carriage by water was probably more secure than by cart or coach and horseback. The REED records show how popular the coastline in particular of Sussex and Kent was for visiting companies, and with so much penetration by river inland to towns like Margate and Canterbury it is hard to see how often the London-based companies would have chosen instead to pack themselves up onto wagons and horses for their travels.

To take only one example of likely sea travel, the early Admiral's company, taking Tamburlaine and Faustus on tour in 1590 and 1591, played on successive days at Maidstone, Folkestone, Lydd, Rye, Canterbury, New Romney, and then Bristol and Gloucester, all easily accessible by water. On the few occasions when the local clerks supplied a precise date for the visits they seem to show the performers appearing at different ports on successive days, a speed of travel that suggests they might even have used their coastal transport to sleep on as well as for transport of their numbers and their properties. ${ }^{3}$ In all, their recorded stops around the south coast, either to seaports or upriver to major towns, included (starting from London) Maidstone, Faversham, Fordwich (the river halt for Canterbury), Sandwich, Dover, Hythe, Folkestone, New Romney,

\footnotetext{
3 The evidence for this company's travelling practices is assembled in Gurr (2009:7679,289-292), with a map of their stops (74). This evidence for their tours has been assembled from the multiple volumes of the Records of Early English Drama (1979-).
} 
Lydd, and Rye. Further round the south coast their stops included Southampton, Lyme Regis, Exeter and Plymouth. The Shakespeare company did rather less travelling, but their stops certainly included Faversham, Fordwich, Dover, Hythe, Folkestone, New Romney, and Rye (Gurr 2004:54-69). On round the coast and up the Bristol Channel both companies used to perform at Barnstaple, Bristol and Bath, all towns accessible by water, before stopping at Marlborough and Oxford on their way back to London.

The ease of travel by water not only on sea but inland by river, including to Stratford, is another case where our thinking is likely to go off course. Let me cite an instance with which anyone who has ever walked along a towpath by a river in England will be familiar. Paths alongside rivers originally made for horses hauling barges are still common features of the English landscape. The Calendar of State Papers (CSP Domestic) gives us an example from Elizabethan times of the legal issues that faced landowners who denied bargemen their right to such paths. The Privy Council was regularly occupied with keeping waterways navigable on all the major rivers of England. On 6 May 1594 two justices at Serjeant's Inn issued a report to the Council over a dispute about the River Lea, between Ware and the Thames in London. Amongst other points, it declared that the river, in a suit over ancients rights of way on the river and its banks, had legal status as a routeway for water traffic, and that in consequence international law required its routeways always to be kept clear for transport.

Where it was alleged that certain vessels called shutes had anciently passed down the river, and were of very small burden, it was proved by record that in Edw. III's time, three shutes passed down, carrying 12 loads of timber, which was four tons apiece, and in Hen. IV's time, another carried 12 tons of timber, at one time, down the river, and some of the barges lately passing are six or seven tons burthen.

It was also alleged by the defendants, that though the river was navigable, it was not lawful for the bargemen to go on land to tow their barges; to which it was answered, that the river, being one of the great rivers of the realm, has the same liberties as others have, and that bargemen and keelmen have always used to go along by the bankside to draw their vessels, by the rivers of Thames, Severn, Trent, and the river between Wisbech and Cambridge, and sometimes have the help of horses to tow up their vessels, and that the like liberty is always allowed to the navigable rivers 
in Holland, Zealand, and all foreign parts. Bracton states that the use of the banks of rivers is public, by the law of nations, like the rivers themselves; as also fishermen may go upon any man's land to dry their nets, because it is good for the commonwealth.

In the time of Edw. IV. the owners of the ground on either side the river were ordered to take away all trees and hedges growing upon the banks, which could serve to no other end but that the bargemen might go upon the banks to tow their barges. The late Commissioners of Sewers have caused all the trees, bushes, \&c. upon the banks to be taken away, and bridges to be made over the mouth of mill-streams, for the bargemen to go along the banks and tow their barges; also it is impossible to carry up barges or boats of any burden against the stream with oars only, and the bargemen, going on land and keeping one path, could do little or no hurt to the land. (Green 1867:501-502)

The importance of travel by river throughout Tudor and Stuart England is exemplified in some wonderful doggerel verses by, inevitably, John Taylor the Water Poet. On 25 July 1622, for instance, he started on a journey whose experiences he versified as "A Verry Merry Wherry-Ferry-Voyage: or Yorke for my money: sometimes perilous, sometimes quarrellous, performed with a paire of oares, by sea from London, by John Taylor and Job Pennell, and written by J. T." The two rowers set out from Gravesend in a wherry, described as "somewhat old, or strucke in age, / That had endur'd neere 4. yeares pilgrimage, / And caryed honest people, whores, and thieves, / Some sergeants, bayliffes, and some under-shrieves." Besides its pair of oars it had a single sail for propulsion through the deeper seas. Down the Thames beyond Colchester they put out to sea towards the Naze, but the wind began to blow hard ("Stiffe Eolus with Neptune went to cuffes," as Taylor put it), and while bigger ships had to strike their topsails, "Meane time (before the wind) we scudded brave, / Much like a duck, on top of every wave. / But" (mercifully) "nothing violent is permanent, / And in short space away the tempest went." They spent the night in Harwich, and then rowed past Aldeburgh to Yarmouth, where they spent a good night, and the next day, a Sunday, heard a sermon and ate a good cheese before rowing on through heavy waves to Cromer. There, at the most northern of the Cinqueports, they were arrested. Taylor is derisive:

As sheepe doe feare the wolfe, or geese the fox,

So all amazed were these sencelesse blockes: 
That had the towne beene fir'd, it is a doubt,

But that the women there had pist it out,

And from the men reek'd such a fearefull sent,

That people three miles thence mus'd what it meant.

The local militia spent all day till 3 o'clock ransacking and smashing bits of the boat, until one of the local magistrates finally remembered Taylor's well-known writings and invited them to his house, four miles off. Taylor took care to name the four chief locals responsible for the uproar, who had cost them most of a good day for sea travel.

From Cromer they rowed on up the coast to the Wash, which they hurried through past perilous masses of low sand dunes and unmarked water with strong tide-rips, rowing a hundred miles in the one day, till they got to Boston in Lincolnshire, north of the Fens. The next day they rowed fifty miles up the River Witham to Lincoln, and then north again by shallow and muddy streams (it took them 8 hours to go 9 miles) to Gainsborough on the Trent, and on up to the river Humber, where the wind proved too strong for them and they were swept fifteen miles downriver to Hull instead of their intended upriver destination, York. Being another Sunday the mayor of Hull gave them welcome and food, and many others gave them help in getting to York, "Their loves (like Humber) over-flow'd the bankes, / And though I ebbe in worth, I'le flowe in thanks." They reached York, their destination, on 7 August, having rowed more than three hundred miles in thirteen days. In York they sold their boat (and lots of Taylor's books), and returned to London by horse. The verses that cover the return journey take 24 lines, against 820 for the first and more watery part of their epic. You can see Taylor's own priorities in that.

Ten years later, in 1632, following work he joined in that identified the need to improve the Thames's upriver route out of London, he offered a rhyming version of a voyage he made on the Thames between Oxford and London. His account listed its various impediments, notably over the forty miles from Oxford to Staines, plus a number of difficulties they endured through the last twenty miles to the city:

Neare Eaton College is a stop and weare (weir),

Whose absence well the river may forbeare;

A stop, a weare, a dangerous sunke tree,

Not farre from Datchet Ferry are all three. 
(That location on the Thames, incidentally, is where the 2012 Olympic rowing course is set). I particularly like his comment on Chertsey Bridge:

Tumbling 'twixt Middlesex and Surrey land,

We came where Chertseyes crooked bridge doth stand,

Which sure was made all by left-handed men,

The like of it was never in my ken. ${ }^{4}$

Taylor was an honest man, who used his own vast experience of life in London and England to tell many stories about life under the Stuart kings. His accounts cover land travel as well as his own water excursions. Among his many small pamphlets is a practical guide to the names of the great inns in the city which were used as bases from which the carriers who could transport people and goods to the remote towns in England set out, complete with their charges and which days they went and which they returned on.

Thomas Kyd's fascination in The Spanish Tragedy with the threat that the union of Spain with Portugal posed to English and Dutch adventuring on the high seas, and the way that King Phillip's takeover of Portugal disposed of Alexander VI's decree dividing the world outside Europe between Spain and Portugal, so intensifying the threat to English trade, has been well established. It is the vital frame for reading the play. Philip Edwards himself, the play's best editor, has written a splendid book on global expeditions by sea. I only wish that when he edited the play he had more knowledge of local conditions than his derision over Kyd's using the sea shows. It was in the 1580s, when the play was written, that Phillip II banned all ports on the Iberian peninsula to English and Dutch shipping. Such a local threat to London's many merchants immediately imposed itself as a political crisis on thinking in London. As I have said, Kyd's own schoolmate, Thomas Lodge, was on a ship in Terceira in the Azores when Don Antonio's struggle against the Spanish was still going in, and I suspect that most of the politics behind the play started with what Kyd learned from his discussions with Lodge about his experiences in there. But let us at the end turn back, as we so often do, to Shakespeare's own slim testimonies to his knowledge of sailing.

\footnotetext{
${ }^{4}$ Quotations from Taylor's work are taken from Chandler's Travels through Stuart Britain: the adventures of John Taylor, the water poet (1999).
} 
It is worth noting that six of his plays have shipwrecks in them. Disasters at sea were almost the classic means of launching a romantic story, as they do in Comedy of Errors, Twelfth Night, Pericles and The Tempest. ${ }^{5}$ They show ample evidence of the poet's familiarity with ships at sea, and storms, not least in the vigorous and realistic opening scene of The Tempest. Here I offer just two quotations which suggest something of what Shakespeare thought about travel by sea. Neither of them is very complimentary about its perils. Both of them in fact employ a rather strange word for a boat. One comes from about 1602, Troilus and Cressida 1.3.34 (TLN 490-493), where Nestor is trying to soothe the angry Agamemnon with a metaphor about the changeable seas:

The Sea being smooth,

How many shallow bauble Boates dare saile

Upon her patient brest, making their way

With those of Nobler bulke?

Bauble boats? Or boats which are like bubbles on the froth of stormy seas? The adjective here sounds emphatic, a dismissive word. Whether Shakespeare gave it a Warwickshire pronunciation, or was merging it with the more common water-word bubble, we cannot easily tell. Baubles and bubbles, froth on the water, were of course as light as the bauble reputation that soldiers and seamen sought even in the cannon's mouth, according to Jacques's seven ages speech. Perhaps Shakespeare pronounced the two words as one, a bubble becoming in his Warwickshire accent the more emphatic bauble. More commonly, we know that the second pronunciation is also the term Petruchio uses to describe Katherine's cap in The Taming of the Shrew. More suggestively it was also the routine word for the fool's stick, the clownish and sometimes erotic instrument that Robert Armin used as his ventriloquist's dummy for his solo acts. I would prefer the idea that Nestor is thinking of a bubble rather than a clown's stick, but either or both meanings are possible.

\footnotetext{
${ }^{5}$ In this paper I have avoided discussing the multiple niceties of Shakespeare's own sense of world geography, since it is not intrinsically dependent on his own likely experience of voyaging. John Gillies (1994) opens this subject out very clearly. More recently, Lorena Laureano Dominguez (2009) has augmented the scope of Gillies' account very impressively.
} 
The other quotation is from Cymbeline 3.1.27 (TLN 1402-1408), when the Queen tells her son about how feeble is Rome's demand of tribute from England:

A kind of Conquest

Caesar made heere, but made not heere his bragge

Of Came, and Saw, and Over-came: with shame

(the first that ever touch'd him) he was carried

From off our Coast, twice beaten: and his Shipping

(Poore ignorant Baubles) on our terrible Seas

Like Egge-shels mov'd upon their Surges, crack'd

As easily 'gainst our Rockes.

Here the triviality of the word when applied to Caesar's Roman ships, their fragility as egg-shells when confronted with England's rocky coast, makes the Queen's contemptuous dismissal quite obvious. The word that both of these eloquent and dismissive passages share is "Baubles." It fascinates me that Shakespeare should use such a trivializing term in these quotations as a recognizable description of the small seagoing craft that he probably used himself on his travels round England. In these two speeches about sea voyages he makes it in complex ways the most apt word for the light vessels, as fragile as an eggshell, both literal and metaphorical, that any group such as a company of players would have to ride in when they travelled around England. Such baubles, frail as they are, are not to be ignored.

\section{References}

\section{(a) Primary sources}

Green, Everett ed. 1867. Calendar of State Papers Domestic 1591-1594. London: Longman.

Hakluyt, Richard 1589. The Principall Navigations, voiages, and discoveries of the English nation. London: George Bishop and Ralph Newberie.

Lodge, Thomas 1590. Rosalynde. London: Imprinted by Thomas Orwin for T.G. and John Busbie.

Port Books. UK National Archive E190.

Taylor, John 1622. A Verry Merry Wherry-Ferry-Voyage: or Yorke for my money: sometimes perilous, sometimes quarrellous, performed with a paire of oares, by sea from London, by John Taylor and Job Pennell, and written by J. T. London: Imprinted by Edw: All-de. 
A. Gurr

\section{(b) Secondary sources}

Chandler, John ed. 1999. Travels through Stuart Britain: the adventures of John Taylor, the water poet. London: Sutton.

Edwards, Philip 1988. Last Voyages. Cavendish, Hudson, Raleigh. Oxford: Clarendon Press.

Edwards, Philip 1997. Sea-Mark. The Metaphorical Voyage, Spenser to Milton. Liverpool: Liverpool University Press.

Gillies, John 1994. Shakespeare and the Geography of Difference. Cambridge: Cambridge University Press.

Gurr, Andrew 2004. The Shakespeare Company 1594-1642. Cambridge: Cambridge University Press.

Gurr, Andrew 2009. Shakespeare's Opposites. The Admiral's Company 15941625. Cambridge: Cambridge University Press.

Johnston, Alexandra F. et al. eds. 1979-. Records of Early English Drama, Toronto University Press, Toronto.

Kyd, Thomas 1959 (1587?). The Spanish Tragedy. Ed. Philip Edwards. London: Revels Plays, Methuen.

Laureano Domínguez, Lorena 2009. "Pericles' 'unknown travels': the dimensions of geography in Shakespeare's Pericles." SEDERI 19: 71-97.

Maltby, William S. 1983. Alba: A biography of Fernando Alvarez de Toledo Third Duke of Alba 1507-1582. Berkeley: University of California Press.

How to cite this article:

Gurr, Andrew. "Baubles on the water: sea travel in Shakespeare's time." SEDERI 20 (2010): 57-70.

Author's contact: a.j.gurr@reading.ac.uk

Submission: 29/04/2010

Acceptance: 06/05/2010 


\title{
Macbeth and the Passions' "Proper Stuff"
}

\author{
Zenón Luis Martínez \\ Universidad de Huelva
}

\begin{abstract}
This essay examines early modern conceptions and representations of the passions in relation to issues of selfknowledge in texts ranging from Renaissance psychology to Shakespearean tragedy -with a particular focus on Macbeth. Considered in essence processes of the mind, the passions were believed to manifest themselves through material symptoms such as bodily effects, facial gestures and discourse. Accordingly, the early modern philosophy of man saw in the study of these material manifestations a vehicle to access the soul. By tracing the methodologies for translating the material side of human experience -words, gestures, bodily sensations and signals- into less material truths, early modern philosophy and theatre explored the certainties about inwardness as a necessary dimension of the self, as well as the uncertainties about the ultimate essence of such interiority. In this, Shakespeare's Macbeth, for its constant focus on outward appearance and rhetoric, stresses the need to focus on matter as a vehicle to explore interiority. And yet -and in keeping with the principles of earlier Renaissance humanists- the play acknowledges the utter impossibility to know the ultimate essence of the inward self.
\end{abstract}

KEYWORDS: Renaissance tragedy, Shakespeare studies, Macbeth, humanism, rhetoric, (the) passions of the mind.

\footnotetext{
* A former version of this essay was presented at the International Shakespeare Conference (Stratford-upon-Avon, 2006) as part of the seminar "The Possibility of Awareness." I thank Robin Headlam Wells, Robyn Bolam, and Madhavi Menon for responses and comments. I have also benefited from Fernando Navarro's not precisely small Latin.
} 
How aware can one be of one's passions? How aware can one be of others' passions? What follows explores the relevance of these questions for establishing notions of self-knowledge in texts ranging from Renaissance psychology to Shakespearean tragedy -with a particular focus on Macbeth. The aim is not just to assess key aspects of early modern representations of the passions -namely, their ambivalent nature as motions affecting body and mind, their resilience to inspection and interpretation, or the importance of language, rhetoric and gesture as vehicles for their dramatic expression. This essay also takes issue with certain premises of the so-called "corporeal turn" in recent Shakespeare studies. ${ }^{1}$ By stressing the pre-eminence of the body, these studies have often interpreted the dualism of body and soul as a critical misrepresentation of the early modern experience of the self. By contrast, I contend that Renaissance notions of the self were essentially dualistic. Considered in essence processes of the mind, the passions were believed to manifest themselves through material symptoms such as bodily processes, facial gestures and discourse. In keeping with this, the early modern philosophy of man saw in the study of these material manifestations a vehicle to access the soul. Inscrutable in substance, but accessible through its functions, the inward self was regarded as a mystery worthy of examination. By tracing the methodologies for translating the material side of human experience -words, gestures, bodily sensations and signals- into less material truths, this essay explores, in theory and in theatre, the early modern certainties about inwardness as a necessary dimension of the self, as well as the uncertainties about the ultimate essence of such interiority. ${ }^{2}$

\footnotetext{
${ }^{1}$ I borrow the phrase from Baumbach (2008:13-14), who derives it from Elam (1996:143), and provides several useful bibliographical instances in footnote.

2 My study thus departs from those critical attempts to refute interiority as constitutive of the Shakespearean tragic self, with special reference to Hamlet. A locus classicus is Barker's affirmation that "interiority remains, in Hamlet, merely gestural" (1984:36), an argument that this paper takes issue with. Other recent instances are Cefalu (2004:145-172), who contests "impressionistic 'inwardist" readings of Shakespeare (148), or Paster (2004a), more amply discussed below. In this sense, my study tallies, in spite of differences, with that of Maus, whose project explores "the afflictions and satisfactions that attend upon the difference between an unexpressed interior and a theatricalized exterior" (1995:2). My view of Renaissance notions of the inner self is basically coincident with Headlam Wells (2005). Beyond the theatre, and before the advent of Cartesian conceptions, the concern with the differences between
} 


\section{Know thy self}

Commenting on the uses of history, Juan Luis Vives wrote in De Tradendis Disciplinis (1531) that "those things that are contained in our natures never change, such as the causes of the affections of our minds, and their actions and effects, and that is more important for us to know than how men in Antiquity erected buildings, or how they dressed." An affirmation that leads him to ask:

What greater prudence is there than to know how and what the human passions are: how they are roused, how quelled? To know also what influence they can bring to bear on the commonwealth, their motivating forces, how they can be contained, healed, put aside or, on the other hand, inflamed and fomented, whether in others or ourselves? What can be more expedient either for the ruler of a city or for any of his subjects to know? And what can be more delightful, what more conducive to the most fruitful kind of prudence? ${ }^{3}$

Vives's point is eminently pragmatic: as a vehicle to the self, knowing one's passions brings not only ethical rewards but also political advantages. This must have justified Niccolò Machiavelli's similar preoccupations a few years earlier, as he reminded his readers -here via a mid seventeenth-century English translator- that "every man may come to see what thou seemest, few come to perceive what thou art." In a similar vein the English humanist Thomas Newton translated a well-known adage in Cicero's Somnium Scipionis thus: "Neither art thou that which thy outward form and shape declareth; but the mind and soul of every man is he, and not that figure and shape which may be pointed and showed with the

outward and inward selves has a long tradition in Western philosophy. As David Aers reminds us, "the whole medieval penitential tradition involves a fundamental and perfectly explicit distinction between inner and outer, between that which is within and passes show and that which is without, the external act" (1992:85). On the inner self see also Taylor (1989:esp. 111-142).

3 "Sed illa tamen nunquam o mutantur, quae natura continentur: nempe causae affectum animi, eorumque actiones, \& affecta, quod est longe conducibilius cognoscere, quam quomodo olim vel aedificabant, vel vestiebant homines antiqui. Quem enim maior est prudentia, quam scire, quibus ex rebus, qui hominum affectus vel conciantur, vel sedantur? Affectus porro illi quae adferant momenta in republica, quos motus, quamadmodum continendi, sanandi, tollendi, aut contra exagitandi, \& confondendi sive in aliis, sive in nobis ipsis?" (Vives 1612:350). The translation is Foster Watson's (1913:232). 
finger." Which he glossed marginally: "A man is his mind." ${ }^{4}$ At stake here is also the discontinuity of inward substance from outward appearance. The English Jesuit Thomas Wright, in his then widely read and now re-discovered The Passions of the Minde in Generall, argued that "as the motions of our Passions are hid from our eyes, so they are hard to be perceiued" $\left(1604: \mathrm{D}_{7}^{\mathrm{r}}\right)$. The emphasis is once again the opacity to the senses of the operations of our minds.

These statements show not only the practical importance of selfawareness and awareness of others, but also the intellectual assurance that the inward self, whose essence was conceived of as separable from a universe of outward materiality, was the ultimate target of this kind of knowledge. The insufficiency of our senses in our attempts to access the self sustained the Renaissance principle nosce teipsum. For Christian humanists, self-knowledge was a high ethical aspiration of the rational soul, whose search for truth comprised the elucidation of those processes originating in the human mind and body, and conditioning action and behaviour. ${ }^{5}$ For Wright, his treatise of the passions

comprehendeth the chiefe obiect that all Philosophers aimed at, wherin they placed the most of their felicitie, that was Nosce teipsum, Know thy selfe: the which knowledge principally consisteth of a perfit experience euery man hath of himselfe in particular, and an vniuersall knowledge of mens inclinations in common [...]. (Wright $1604: \mathrm{B}^{\mathrm{v}}-\mathrm{B}_{4}{ }^{\mathrm{r}}$ )

The passions were understood as motions or perturbations occurring between the material acts of the senses and the nonmaterial processes of the rational soul (Wright 1604: $\mathrm{B}_{4}{ }^{\mathrm{r}}$ ). Their centrality to a theory of the self was justified by this liminal nature and its implications for the spiritual history of humankind: since the corruption of reason by the passions was a condition of the Fall, the

\footnotetext{
${ }^{4}$ Machiavelli (1640:111), and Cicero (1577:fol.130) are both quoted in Soellner (1972:33, 9-10).

${ }^{5}$ In Sir John Davies' words in his poem Nosce Teipsum: "First in mans minde we finde an appetite / To learne and know the truth of euerie thing, / Which is connaturall, and borne with it, / And from the Essence of the Soule doth spring." This stanza is marginally glossed as "Reason. Drawne fro[m] the desire of knowledge" (1599: $\mathrm{H}_{4}{ }^{\mathrm{v}}$ ). Davies describes pre-lapsarian reason as an innocent but all-seeing faculty: "And when their reasons eye was sharp and cleere, / And (as an Eagle can behold the Sunne,) / Could haue approch't th'eternall light as neere, / As the intellectuall Angels could haue done" $\left(\mathrm{Bi}^{\mathrm{r}}\right)$.
} 
neo-Stoic doctrine of self-knowledge meant regaining for the rational soul awareness and control over those perturbations of the sensitive soul. $^{6}$

Renaissance self-knowledge was hence an attempt to police the relations between the outward and inward nature of human beings. Awareness of the contiguity of body and soul, and of the continuity of the sensitive with the rational operations of the latter, lay at the heart of humanist thought. As long as the passions concerned bodily functions, their effects admitted description from the perspective of physiology and medicine. ${ }^{7}$ But this familiarity of body with mind, of the sensitive with the rational, was perceived, if not with anxiety, at least as an unsolved contradiction..$^{8}$ Descriptions of the workings of the passions were the effect of the belief in the humoural composition of the self: the passions originate in the middle part of our soul -the so-called sensitive soul- which is shared by men and animals, and which mediates between the vegetative soul -the one humans and animals have in common with plants- and the rational soul -owned by humans and angels alike. The imagination, a faculty of the sensitive soul, derives impressions of external objects from the senses, and summons up the presence of the purer spirits from the brain into the heart, which, influenced by the four bodily humours,

\footnotetext{
${ }^{6}$ Sir John Davies recounts it thus: "Euen so by tasting of that Fruite forbid, / Where they sought knowledge, they did error find, / Ill they desir'd, and ill they did; / And to giue Passion eyes, made Reason blind. / For then their minds did first in passion see, / Those wretched shapes of Miserie and Woe, / Of Nakednesse, of Shame, of Pouertie, / Which then their owne experience made the $[\mathrm{m}]$ know" $\left(1599: \mathrm{B}_{1}{ }^{\mathrm{r}}-\mathrm{B}_{2}{ }^{\mathrm{r}}\right)$. In Soellner's words, "self-knowledge had for Shakespeare and his audience a different emphasis from what it has for us. In most cases, the primary reference is to control of passion by means of reason" (1972:xiv).

${ }^{7}$ This issue is emphasised in recent work on literary representations of the passions. See the "Introduction" to Paster, Rowe, and Floyd-Wilson (2004), and also Paster (2004).

${ }^{8}$ As a conclusion to his learned discussion, Kocher provides an enlightening summary of this issue: "Being at a loss to know what to do with incomprehensible spirit, and finding it methodologically expendable in their study of the system of matter, many physicians acted as if it were not there. Psychologists, of course, were in much less danger of forgetting the soul, but they were unlucky victims of the great Elizabethan dualism. Of the two constituents of psychology, matter and spirit, one seemed to belong to the medical sciences, the other to ethics and religion. It is altogether fascinating to watch psychologists veering from one to the other, trying to hold together a topic which persisted in flying apart into halves separated by a metaphysical vacuum" (1953:305).
} 
pursues or eschews those very objects represented by our imagination. " "Blindnesse of vnderstanding" and "peruersion of will" were common effects of vehement passions, since the imagination was assumed to be responsible for representing to the understanding the good or evil of the objects it sought or avoided (Wright 1604:D8 ${ }^{r}$ ). In this sense, blaming the imagination and fantasy for interfering with the rational soul was a common attitude in Renaissance thought. ${ }^{10}$ The English physician Timothy Bright reminds us, for instance, in his Treatise on Melancholie (1586) that the imagination, under the effect of a surplus of melancholy humours, causes "fantasticall apparitions," whereas fantasy "compoundeth, and forgeth disguised shapes" (103).

But as long as the passions were conceived as perturbations originating in the inward soul, and thence as discontinuous with bodily matter, knowledge of them became a more problematic issue. Wright's insistence upon the passions' inaccessibility to our perception testifies to the problems involved. The fourth book of his treatise, devoted to explaining "how passions may be discovered," endeavoured, like Polonius, by indirections to find directions out, and hence advised methods of finding inward truths by observation of outward realities:

For that we cannot enter into a mans heart, and view the passions or inclinations which there reside and lie hidden; therefore, as Philosophers by effects find out causes, by properties essences, by riuers fountaines, by boughs and floures the kore and roots; euen so we must trace out passions and inclinations by some effects and externall operations; and these be no more than two, words \& deeds, speech and action: of which two, knowledge may be gathered from those affections we carry in our minds. $\left(\mathrm{H}_{5}{ }^{\mathrm{r}}\right)$

For Wright the "heart" and the "mind" were as central to passionate arousal as were their activities unattainable to external perception. Discovery of the passions needed to be pursued somehow obliquely. In Wright's description, obliqueness reveals a character which, from a semiotic point of view, may be called indexical and, from a rhetorical one, metonymic. Both concepts

\footnotetext{
${ }^{9}$ Most Renaissance psychological treatises account for this process in very similar terms. General accounts with many learned references can be found in Lily B. Campbell (1930:63-72), and Bamborough (1952:41-45).
}

${ }^{10}$ On derogatory views of the imagination, see Rossky (1958). 
comprise relations of contiguity and causality, as well as of presence and absence. As in our empirical observations of nature, Wright seems to suggest, we must arrive at the ultimate causes of human action through detection of external signs that are little else than effects of an elusive inward truth. As long as this becomes our basic mode of awareness, a universe of bodily fluids, organs and sensations dissolves into a referential network of speech and action whose nature is ultimately rhetorical. No wonder that since Aristotle rhetoricians had paid primary attention to the orator's ability to represent and to incite certain passionate states. ${ }^{11}$ At the level of speech, rhetorical inventio, dispositio, and elocutio shape representations of passionate processes, while they are themselves determined by the speaker's own emotions. At the level of deeds, rhetorical actio wraps the oratio in countenances, gestures, voices, intonation, and movements.

Among the various indices that guided the external observation of the passions, the face was a chief site of awareness. "Face" is a term whose early modern meanings range from "the front part of the head," the "visage," to more ample figurations of outward appearance. ${ }^{12}$ For Thomas Wright, "it cannot be doubted of, but that the passions of our mindes worke diuers effects in our faces," and for that very reason "wise men often, thorow the windowes of the face, behold the secrets of the heart:"

As the face of those which looke into waters shine vnto them, so the hearts of men are manifest to the wise [Prov. 27.18]: not that they can exactly, understand the hearts which be inscrutable, and only open unto God, but that by coniectures they may ayme well at them: for as he which beholdeth his face in the water, doth not discern it exactly but rather a shadowe, than a face; even so he that by external phisiognomy and operations will divine what

\footnotetext{
${ }^{11}$ The locus classicus for discussion of the passions in rhetoric is Book II of Aristotle's Rhetoric (1926:II.i.8). Quintilian's Institutio Oratoria provides a clearest formulation of this principle: "Quare in iis, quae esse verisimilia volemus, simus ipsi similes eorum qui vere patiuntur adfectibus, et a tali animo proficiscatur qualem facere iudicem volet" [Thus in those emotions, which we want to be verisimilar, we should be ourselves similar to those who verily suffer from those affections, and the speech should emerge from the same emotion as it intends to produce in the judge] (1921:2, VI.ii.27). I have followed this edition's Latin text but not the translation, which is my own.
}

${ }^{12}$ These are the main meanings of the word as defined in the OED (sense I and II). 
lieth hidden in the heart, may rather conceive an image of that affection that doth reign in the mind than a perfect and resolute knowledge [...]

And thus to conclude, we must confesse, that Passions haue certain effects in our faces, howbeit some doe shew them more evidently than others. Yet we may not say, that this face is the root \& core where the Passions reside, but only the rinde and leaues, which shew the nature and goodness of both the root and the core. $\left(\mathrm{C}^{\mathrm{r}}\right)$

Interpreting the face was then a form of insight or discernment, that is, the capacity of obtaining hidden truths from the examination of outward features and changing gestures. Yet Wright, a strongminded believer in this method, also informs us of its shortcomings: even the shrewdest examiner, Wright implies, must be content with conjectures that originate in external signs always at risk of misreading the self.

The examination of the face found its roots in the disciplines of physiognomy and rhetoric. The status of physiognomy as a science had fallen into discredit in the Renaissance. However, as Hardin Craig observed long ago, popular forms of knowledge in the English Renaissance frequently sought "short cuts to the absolute, back stairs approaches to certainty, get-rich methods of acquiring truth" (Craig 1927, qtd. in Camden 1941:400). The popularity of the pseudoAristotelian Physiognomonia during the Middle Ages was followed by the success of treatises like Giambattista della Porta's De Humana Physiognomonia or, in England, Thomas Hill's The Contemplation of Mankinde, or A Pleasant History Declaring the Whole Art of Physiognomy, whose various editions from 1571 to 1616 in the printing press of William Jaggard appear to have left a significant trace. ${ }^{13}$ Physiognomy, Hill admits, "instructeth a man by the outwarde notes, to foretell the naturall motions, and naturall conditions, that consist and dwell in many persons, especially in those, which live after their affection, and appetites, rather than gouerning themselues by reason" (1571:2 ${ }^{\mathrm{v}}$ ). Inward motions alter our outward appearance, and for that reason Hill fluctuates between the mechanistic interpretation of the static face and the awareness of accidental motions of the mind as inferred from changing gestures.

${ }^{13}$ On English Renaissance physiognomy and its precedents see Camden (1941), and Baumbach (2008:esp. 26-44). 
As he asserts, "in a man the face remayneth, but the countenaunce doth alter: so that the countinaunce is named of the Latine worde Volando, which properly in Englishe signifieth a flying, or vanisihing away" (1571:90 $\left.{ }^{r}\right)$. Hill produces physiognomic truth through bizarre linguistic operations: "face" and "countenance," two words frequently seen as interchangeable synonyms, are given differentiated meanings: human beings have unchanging faces but are capable of a multiplicity of meaningful gestures by setting their faces in motion, and thus the human "countenaunce" is as volatile as the Latin word which is adduced to be its etymological source. ${ }^{14}$

Physiognomic wisdom endured in part for its connection with the art of rhetoric. The influence of Ciceronian oratory was crucial in this sense. Cicero's detailed account of delivery or actio in De Oratore devoted a whole chapter to the role of gestus in the expression of motus or passions. In Cicero's words, "animi est enim omnis actio, et imago animi vultus, indices oculi; nam haec est una pars corporis quae quot animi motus sunt tot significationes et commutationes possit efficere" ["delivery's main concern is with the emotions, and the passions are mirrored in the face and expressed by the eyes; for this is the only part of the body that can produce as many meanings and variations as there are passions of the mind"] (Cicero 1942:III.lix.221; my translation). Unlike in physiognomy, whose main object was the static face or facies, the rhetorician's concern with vultus addresses the self-conscious ability to produce modulations and variations. ${ }^{15}$ The orator's face is not merely a passive mirror to

\footnotetext{
${ }^{14}$ Hill's etymological deductions are surprising. To find connotations of flying and changeability in a word whose form and meaning were commonly merged with those of "continuance" and "continence," and therefore, with ideas of contention and stability, is amusing enough. The Latin terms facies and vultus, and Italian faccia and volto, are pairs matching "face" and "countenance": the first undoubtedly provides the etymological origin of "face"; we might search in the second and its Englishing "vult" -for which the OED registers usage between 1375 and 1610- and find a not very outrageous phonetic closeness to Latin volare. John Florio's Italian-English dictionary A World of Words (1598) points at the homonymy of volto in Italian, meaning "a face, a looke, a countenance, a visage, a fauour or cheere of man," but also signifying, as an alternative conjugation of the past participle volgiuto, of vólgere, "turned, overturned, tossed, $\mathrm{t}[\mathrm{r}] \mathrm{ubled}$, transformed, revolted, changed, inclined, bent [...] revolted to and fro" (455), a word which in English gives "vault", meaning "leap", "jump high", "rise", "surmount", as in Shakespeare's "vaulting ambition, which o'er-leaps itself" (Macbeth 1.7.27). All references to this play are from Braunmuller's edition (1997).

${ }^{15}$ The grammarian Nonius Marcellus differentiates these terms by stating that "vultus est voluntas quae pro moto animi is facie ostenditur" [the countenace is our will as it
} 
the mind, and hence the importance of practical rhetoric in the training of Elizabethan players in the arts of feigning. ${ }^{16}$

So far we have seen two paths by which the Renaissance explored the nature of human passions: one addresses the phenomenon, and its subjects are inward motions, disturbed minds, troubled souls, and altered bodily organs and fluids; the second involves its access through signs and indices, and its subjects are words, deeds, and faces. The crossroads is the insistence upon external observation as a necessary, though faulty and incomplete, aid to human insight. In its self-assumed role as imago mundi the theatre became a privileged vehicle for the exploration of the relationships between inward and outward nature, between external movements and inner motions, between seeming and being. Shakespeare and his contemporaries show a concern with the gaps and fissures on the paths that led from indices to their alleged truths. The Shakespearean poetics of the passions addresses not the denial of the inward self, but the paradoxical and incomplete nature of our modes of awareness and insight into its nature. In this Shakespeare's thought was an effect of humanist ideas. Vives, for instance, had concluded in De anima et vita (1538) that "it is not a matter that should be too important for us to know what the soul is, but rather [...] what it is like and what its operations are." ${ }^{\prime 17}$ But Shakespeare's

is shown in the face through the passions of our mind] (2003:III.689). St. Isidore of Seville also explains the difference in his Etymologies: "Facies dicta ab effigie. Ibi est enim tota figura hominis et uniuscuisque personae cognitio. Vultus vero dictus, eo quod per eum animi voluntas ostenditur. Secundum voluntatem enim in varios motus mutatur, unde et differunt sibi utraque. Nam facies simpliciter accipitur de uniuscuisque naturali aspectu; vultus autem animorum qualitatem significat" [Facies is named after the effigy. In it the entire figure of man is shown indeed, as well as knowledge of each person. It is also called vultus, because through it the will (voluntas) of the spirit is shown. In accordance with one's wishes the face changes into various motions, and thence a difference between these terms is found: facies refers to the natural appearance of each person; vultus for its part signifies a state of mind] (1982:II, XI.1.33-34; my translation). Unlike Hill, Isidore made vultus derive from volere (i.e., to wish) and not from volare (i.e., to fly).

${ }^{16}$ On the rhetorical training of Elizabethan actors see Joseph (1951:esp. 60-82), and Thomson (1997).

17 "Anima quid sit, nihil interest nostra scire, qualis autem, et quae eius opera, permultum" (1782:I.xii.332) This idea is emphasized by Marcia L. Colish in her study of Vives' psychology. As she states: “This distinction drawn by Vives between man's essence and his activity springs from his conception of man's intellectual limitations. The essences of things may be objects of wonder; they are not, however, legitimate 
knowledge also unveils its own poetic and theatrical nature: as long as they are arts of feigning, poetry and the theatre find common ground in the art of the rhetorician. Like rhetoric, drama grants to speech and action the value of contrived artifice. But even beyond the orator's, the poet's, and the dramatist's art, gestures and words are the central indices to everyday concerns with show and tell, concealment and silence, betraying and revealing, discovery and misinterpretation. In the act of bearing themselves in the world, of showing or concealing their aims from others, individuals deal with words and action in rather histrionic ways. Shakespeare understood drama as a rhetorically enhanced form of these concerns: the theatre displays the arts of feigning, imitation and counterfeit in order to emphasize the many fissures found in processes of self-awareness. The focus on Macbeth here is justified by the play's obsessive examination of the relationship between outward and inward realities: ${ }^{18}$ in Macbeth Shakespeare engages in an unflinching search for the inward soul, understood as an organic, controlling and primarily non-material entity - what the play's hero calls "my single state of man" (1.3.141). The play seems to declare, quite paradoxically but with genuine scepticism, that the impossibility of knowing the inward self properly and completely is one condition of its existence. In his investigation of the passions of the mind, Shakespeare understands the theatre as the art of suggesting that there is always more to know about the inward self, though no accurate ways of knowing it. $^{19}$

objects of knowledge. Although Vives as well as Pico is concerned with selfknowledge and repeatedly enjoins to seek it, he does not think that a grasp of the essence of the soul falls within its scope. The intrinsic nature of the soul remains hidden from man [...] God has not granted us the faculties of intelligence, will, and memory so that we may know what they are [...] When Vives does at length analyze the nature of the soul, he proceeds not by definition but by description, in terms of its functions and aptitudes" (Colish 1962:11).

${ }^{18}$ For the import of vision and the visual in the play see Diehl, for whom Macbeth "examines the act of seeing and interpreting an uncertain visible world. This uncertainty, and the epistemological questions it raises, sustain the play dramatically and motivate the action" (1983:191).

${ }^{19}$ For other accounts of Macbeth in terms of the passions of the mind, see Campbell (208-239), whose account of the play as "a study in fear" continues to be useful. See also Kirsch (1972:76-103). The classic psychoanalytical view is Freud's 1916 essay (1977:151-175). See in this respect Kerrigan (1996). 


\section{The mind's construction in the face}

In the first act of Macbeth a distressed Duncan complains about the Thane of Cawdor's treachery in terms that betray a thorough disavowal of physiognomy: "There's no art / To find the mind's construction in the face; / He was a gentleman on whom I built / An absolute trust" (1.4.11-14). We should note that the face that has deceived Duncan is one that the audience will not see, since neither Cawdor's participation in the wars nor his execution are scenes of the play. Cawdor is a name but not a character, and thus the king's words may easily divert our attention outside the play's action -we thus judge them on the basis of an alleged long acquaintance of the king with his thane. Duncan expresses his inability to have read his man of trust's true meaning in the past, as well as his present disappointment -hence his words advance his later failure to interpret Macbeth's mind. ${ }^{20}$ Yet this reading ignores the fact that the Thane of Cawdor does gain, at least indirectly, some sort of physical and psychological presence in the play through Malcolm's words, which narrate Cawdor's death by execution in an act of rhetorical enargeia. ${ }^{21}$ Malcolm has not seen Cawdor's death, but has spoken "with one that saw him die" (1.4.4). In Malcolm's second-hand version of the eye-witness's reporter, Cawdor "very frankly confessed his treasons," and "set forth / A deep repentance" (1.4.5-7; my emphasis). A paradox should be noticed here: the inner depth of Cawdor's repentance -Shakespeare's phrasing hints at the idea of the sinner turning deep inward for self-examination- is "set forth,"

${ }^{20}$ Holinshed must have provided Shakespeare with information on Duncan's weakness. He states that "Duncane was soft and gentle of nature," and adds: "the beginning of Duncan's reign was very quiet peaceable, without anie notable trouble; but after it was perceived how negligent he was in punishing offenders, manie misruled persons tooke occasion thereof to trouble the peace and quiet state of the common-wealth, by seditious commotions which first had their beginnings in this wise" (1586:II, fol. 168/2/24-25, 33-39).

${ }^{21}$ A locus classicus for the definition of enargeia is Quintilian's Institutio Oratoria: "Insequitur enargeia, quae a Cicerone illustratio et evidentia nominatur, quae non tam dicere videtur quam ostendere; et adfectus non aliter, quam sirebus ipsis intersimus, sequentur" ["This is followed by enargeia, which in Cicero is called illustratio and evidentia, which seems not so much to narrate as to exhibit; and affections will be presented no less than if we witnessed the very same things"] (1921:2,VI.ii.32; my translation). English Renaissance accounts of enargeia were based on these classical definitions as well as Erasmus's De duplici copia verborum ac rerum (1521). A useful summary is Doran (1954:242-244). 
that is, laid out, produced outwardly, delivered by means of words, gestures and faces. Malcolm's words leave us with the doubt whether Cawdor's outward show is a window to a true repentant soul, or whether this "deep repentance" constitutes a theatrical display, a hypocritical gesture concealing behind the facade of sincere remorse a treacherous inward nature. Cawdor's delivery of his "deep repentance" is the object of Malcolm's tale:

[...] Nothing in his life

Became him like the leaving it. He died

As one that had been studied in his death,

To throw away the dearest thing he owed

As 'twere a careless trifle. (1.4.7-11; my emphasis)

What others have seen, what Malcolm narrates, and what we must content ourselves with listening to and representing to our imaginations, is Cawdor's success in exhibiting his death as the perfect epitome of Stoic fortitude and temperance. At the moment of his execution, Cawdor proves to be a master of becoming, that is, of decorum. Earlier in the play, Duncan has resolved not to let his inward will be seduced by Cawdor's outward nature again: "No more that Thane of Cawdor shall deceive / Our bosom interest" (1.2.62-63; my emphasis). But now one wonders to what extent Cawdor has, in rehearsing his submissive downfall, taken in Duncan's will again.

As we have to decide on Cawdor's soul, the Renaissance logic of outward versus inward nature may perhaps assist us: Cawdor is a traitor and a hypocrite, and hence a good rhetorician and an actor who has managed to print repentance on his histrionic gestus in order to hide his treacherous meaning. But we may choose a different interpretative path -one that makes Cawdor a much more elusive figure: why can a man that has betrayed his king not be a true model of temperance at the moment of death? Just because these two traits do not sit well together in the often Manichean moral codes of Renaissance tragedy? Cawdor's countenance as described by Malcolm may not be a false but rather true index to a complex, unreachable and enigmatic mind. Duncan's absolute trust or distrust of physiognomy is thus rendered irrelevant by Shakespeare even in its very pronouncement, and we are invited to pursue a different logic: as our ways of access to the inward self are conjectural and subjective -and this we know through Thomas Wright-, so our 
conclusions must be fragmentary and flawed. Seen in this light, Duncan's allegorical role as a foolish prince that cannot construe his subjects' minds reveals him as a model for other characters', as well as the audience's, interpretative shortcomings. And what of Cawdor? He certainly suggests as much about the inscrutability of the inward self as about the intricacies of the early modern art of playing. ${ }^{22}$

Far from overstating the importance of this moment, my reading of Cawdor's behaviour and Duncan's disappointment means to address the play's obsession with the relations between gestural and interior dimensions of the self. As Banquo meets the Wëird Sisters he wonders whether their looks match what they are: "Are ye fantastical, or that indeed / Which outwardly ye show?" (1.3.51-52). And he dares to interpret their minds by dint of their gestures: "You seem to understand me, / By each at once her choppy finger laying / Upon her skinny lips" (1.3.41-43). Later, as Macbeth is first possessed with the temptation to murder Duncan, he exclaims: "Stars hide your fires, / Let not light see my black and deep desires" (1.4.51-52). Macbeth either means that light can penetrate his body and see his passions deep inside, or he actually wishes darkness could mask a face that mirrors the evil of his inward soul. If Macbeth's obsession is with being observed -with his own face betraying his intentions to others-, Lady Macbeth sees herself on the other side as an expert physiognomist. ${ }^{23}$ As she first meets him in Dunsinane, she thinks herself entitled to interpret, borrowing Wright's words, Macbeth's "silent speech pronounced in the very countenance:"

Your face, my Thane, is a book where men

May read strange matters; to beguile the time,

Look like the time, bear welcome in your eye,

Your hand, your tongue -look like th'innocent flower,

But be the serpent under't $[\ldots]$

Only look up clear

To alter favour, ever is to fear. (1.5.6o-71)

\footnotetext{
${ }^{22}$ My reading of this scene challenges Barker's idea of interiority as a merely theatrical, rhetorical, or "gestural" pose (1984:esp. 35-37).

${ }^{23}$ This point has been made recently by Baumbach (2008:128-130).
} 
Lady Macbeth's proficiency as an observer and as a practical advisor is reinforced by the exemplary wisdom behind her words. On the one hand, Geffrey Whitney's emblem 24 in his A Choice of Emblemes (1586) appears as a possible source to her advice, even if Whitney's motto -Latet anguis in herba, [a serpent lies hidden underneath the grass]- and epigram are certainly intended for the sake of virtuous example and not of Machiavellian counsel. ${ }^{24}$ On the other hand, the conceit of a face as a book whose outward marks reveal the innermost essence of a human being is consistent with Renaissance notions of character. Viola's remark to the Sea Captain at the beginning of Twelfth Night provides an interesting instance: "I will believe thou hast a mind that suits / With this thy fair and outward character" (1.2.46-47). ${ }^{25}$ Peter Thomson has reminded us of the perils of misreading "outward character" as an oxymoron, if we understand character merely in the present-day sense of "a property of the psyche." Conversely, Thomson continues, early modern meanings of the word point to "the formation of letters in writing and printing" (1997:321). We should implement Thomson's remark by saying that it is the meaning of character as an outward imprint susceptible of being read -or misread- that determines the Renaissance ideal of an inward signified that can be accessed through signifiers made of outward traits and faces: for lady Macbeth and Viola, Macbeth's "book" and the Captain's "character" are meaningful only as long as they are external realities pointing inwards. But characters and books are sources of knowledge as well as agents of deceit, of good and bad writing, of reading and misreading. In this sense, Lady Macbeth's advice to her husband could perhaps be read in relation to Edward Knowell's recommendations to his cousin, the country gull Stephen, in Jonson's Every Man in His Humour:

\footnotetext{
${ }^{24}$ The first stanza of Whitney's subscriptio addresses the very outward/inward dualisms that with which essay is concerned: "Of flattringe speech, with sugred words beware, / Suspect the harte, whose face doth fawne, and smile, / With trusting these, the worlde is clogg's with care, / And fewe there are can scape these vipers vile: / With pleasing speech they promise, and protest, / When hatefull hartes lie hidd within their brest" (Whitney 1586, in Daly 1998:113).

${ }^{25}$ Another is certainly Sir Philip Sidney's sonnet 71 in Astrophel and Stella: "Who will in fairest booke of Nature know [...]" Sidney's conceited logic leads to the macrocosmic "booke of Nature" to the microcosmos of Stella's "beautie," whose outward show points to inner "virtue:" "That inward sunne in thine eyes shineth so" (Sidney 1931:74).
} 
Come, wrong not the quality of your desert, with looking downward, coz; but hold up your head, so; and let the Idea of what you are, be portrayed i' your face, that men may read i' your physnomy, "Here, within this place, is to be seen the true, rare, and accomplished monster, or miracle of nature," which is all one. (1.3.107-113)

Stephen is tricked into believing that outward arrogance will amend his inward self. Knowell's words fashion the face as a readable motto of inner worth. In the satirical logic of urban comedy, the "true, rare, and accomplished monster" easily reveals Stephen as a false, ordinary, and ridiculous freak. Saving differences in context, genre, and intention, the Jonsonian tag becomes emblematic of what Lady Macbeth attempts to make of her husband. Following her guidance, Macbeth nourishes the fantasy that his outward looks will tell something other than he is: "Away, and mock the time with fairest show, / False face must hide what the false heart doth know" (1.7.82-83).

However, Macbeth's belief in self-control is permanently contrasted with the play's continual focus on his loss of temper, as made clear from the very first encounter with the Wëird Sisters:

\section{[...] Present fears}

Are less than horrible imaginings:

My thought, whose murder yet is but fantastical,

Shakes so my single state of man, that function

Is smothered in surmise, and nothing is

But what is not. (1.3.138-143)

Macbeth's loss of temper, as caused by the thoughts spurring his mixed passions of fear and desire, "shakes" the imagined unity of an undivided mind, whose organic, controlling "function" collapses under the urge of strong imaginations. In this, Shakespeare might seem to tell us, the new Thane of Cawdor lacks the strength of soul shown by his mysterious predecessor.

Macbeth's raptures are a frequent focus of attention. Early on, Banquo notices the protagonist's distemper after listening to the Weïrd Sisters' prophecy: "My noble partner / You greet with present grace and great prediction / Of noble having and of royal hope / That he seems rapt withal" (1.3.52-55; my emphasis). Even if we may not doubt the visual evidence of Macbeth's rapture, whose signs should be shown in performance and whose causes we attribute to 
the impression made by the witches, Banquo presents it as a matter of seeming, that is, of outward show hinting at inward passion. Later in the same scene, after Ross and Angus proclaim Macbeth Thane of Cawdor, he insists on his earlier suppositions: "Look how our partner's rapt" (1.3.140). These are Banquo's words after Macbeth's first long aside: "Two truths are told, / As happy prologues to the swelling act / Of the imperial theme" (1.3.126-128). But awareness of Macbeth's state of mind, even when it appears as unquestionable to us, is for Banquo little else than an impression derived from faces and gestures. Awareness is not necessarily followed by certainty. Using the above-quoted words by Machiavelli, Banquo sees what Macbeth seems but we wonder whether he perceives what he feels, thinks and is. Neither would we if our only path to Macbeth's inward self were our perception of his looks as guided by Banquo. No matter how revealing Macbeth's face is, our closest knowledge of his "true" passions comes from Shakespeare's exercise in rhetorical pathopoeia, presented in the form of an aside: ${ }^{26}$

This supernatural soliciting

Cannot be ill, cannot be good. If ill,

Why hath it given me earnest of success,

Commencing in a truth? I am Thane of Cawdor.

If good, why do I yield to that suggestion

Whose horrid image doth unfix my hair

And make my seated heart knock at my ribs

Against the use of nature? Present fears

Are less than horrible imaginings. (1.3.129-137)

J. B. Bamborough has drawn attention to the importance of socalled "mixed" and "conflicting passions" in Renaissance tragedy (1952:43). Macbeth's words express such a mixture through the conflict between the concupiscible passion of Fear and the irascible passion of Hope, thus showing the mind's split concern for what is to come. ${ }^{27}$ Besides, his account of the workings of these perturbations within his inner self roughly matches the phenomenological description provided above: an external event -the sisters' "supernatural soliciting"- acts as the provoking agent of his passions

\footnotetext{
${ }^{26}$ The Renaissance rhetorician Richard Sherry informs us that pathopoeia takes place when "feare, anger, madnes, hatered, envye, and lyke perturbations of mynde is shewed and described" (1550:Eii). A useful account of the uses of pathopoeia in Renaissance tragedy is McDonald (1966).
}

${ }^{27}$ On traditional classifications of the passions see Bamborough (1952:43-44). 
and suggests itself to the imagination, which, in summoning the spirits and humours to the heart, produces strong bodily impressions. However, the corporeal and mental materiality of this process would be of little value without the text's rhetorical materiality. In this sense, conflicting passions let themselves be shown here by means of rhetorical diuisio or dilemma, which, according to Henry Peacham, occurs "when we divyde a thing into two partes, and reprove them both by shewing reasons" (1577: $\mathrm{T}^{\mathrm{r}}{ }^{\mathrm{r}}$. Macbeth's alternate reproofs of "ill" -the reason for his fear- and "good" -on which his hope is grounded- constitute the most accurate indices to a divided inner mind's disturbance.

Disparity between Banquo's and the audience's forms of access to Macbeth's passions reveals a consistent focus on the difference between the value of gesture and the power of words. Like Duncan, Shakespeare's characters pursue the mind's construction in the face. But the face is a lame index in need of the supplement of words, a dimension reserved for the audience's ears only. The complex game of criss-crossed impressions and reactions to Macbeth's new rapture in the banquet scene is perhaps the best instance of Shakespeare's method. Unlike Macbeth, neither the thanes nor the Queen can see the ghost of Banquo. Like an aside or a soliloquy, the ghost reveals that a full perception of the hero's passions is a matter between the Scottish king and the audience only. However, it is Lady Macbeth that first emerges as mediator between Macbeth and his beholders:

Sit, worthy friends, my lord is often thus.

And hath been from his youth. Pray you keep seat,

The fit is momentary, upon a thought

He will again be well. If much you note him

You shall offend him and extend his passion;

Feed, and regard him not. (3.4.53-58)

Lady Macbeth's awareness points to her husband's outward "fit," taken here as an unmistakeable index to his inward "passion." But her main concern is the degree of the thanes' awareness, and what she can do in order to diminish its scope. Her words intend to produce a misleading gloss of what she mistakenly thinks her husband's passion is, since she fears that her husband's true inner self will become the more conspicuous the longer the thanes "note" and "regard" him. Both verbs betray the pre-eminence of sight in the process of detecting the passions. Lady Macbeth and the thanes rely 
on what they see; conversely, we access Lady Macbeth's fear through what she says:

(aside to Macbeth) O proper stuff!

This is the very painting of your fear,

This is the air-drawn dagger which you said

Led you to Duncan. O these flaws and starts,

Impostors to true fear, would well become

A woman's story at a winter's fire,

Authorized by her grandam -shame itself,

Why do you make such faces? When all's done

You look but on a stool. (3.4.60-68)

At stake in both speeches is the difference between what Macbeth sees -the ghost of Banquo sitting on Macbeth's throne- and what the others see -"a stool." "The very painting of your fear" explains quite accurately the workings of the passions as understood by Renaissance psychology and explained above. "Fear" takes place in the realm of the active imagination, being a secondary derivation of a primary perception of objects through the senses. To see what is not there as an effect of a fit of passion is indeed the imagination's false "painting" under the influence of a vehement perturbation. But to Lady Macbeth the problem is not only what Macbeth can see but also what the thanes could see if they read Macbeth's countenance properly. The King's "fit," his "flaws and starts," and above all, his "faces" may reveal his true self to them. Whereas for Lady Macbeth the king's visions are false "paintings" of his fantasy, his looks and gestures may become true mirrors to his soul. The presence of the supernatural in Macbeth serves here only to remind the audience of the insurmountable gap between being and our awareness of it. The source of Lady Macbeth's unease -her naming "impostors to true fears" those gestures which may become the true harbingers of Macbeth's passions- is her husband's face-making, namely his changing countenance or vultus.

The impressions of a privileged Jacobean playgoer in Shakespeare's time testify to the validity of Wright's description of the process of detection. Dr. Simon Forman in his Booke of Plaies (1611) registers thus his remembrance of the banquet scene from a 1611 performance at the Globe:

The next night, beinge at supper with his noble men whom he had bid to feaste to the which also Banco should have com, he began to speake of Noble banco, and to wish that he wer ther. 
And as he thus did, standing up to drincke a Carouse to him, the ghoste of Banco came and sate down in his cheier behind him. And he turninge About to sit downe Again sawe the goste of Banco, which [af]fronted him so, that he fell into a great passion of fear and fury, Utterynge many wordes about his murder, by which, when they [he]ard that Banco was Murdred they Suspected Mackbet. ${ }^{28}$

Forman names Macbeth's conflicting passions of "fear" and "fury," these being products of an impression upon his sense of sight. ${ }^{29}$ Yet he introduces the new element of the "many wordes about his murder" by which the thanes "Suspected Mackbet." Forman shifts the focus of attention from deeds and faces to words. Macbeth does, as a matter of fact, utter many words about Banquo's murder in this scene, but none which, at least overtly, reveals the deed or Macbeth's responsibility for it, and certainly none which raises the thanes' overt suspicions within the bounds of this scene -it is not until two scenes later that Lennox voices them: "My former speeches have but hit your thoughts / Which may interpret further," he communicates to an unnamed Scottish Lord (3.6.1-2). Forman's memory may be over-reading or misreading the scene when attributing the thanes' suspicions to Macbeth's words -my statement is valid as long as it speculates on a performance whose gesturing does not overdo the plays' script as we know it-, but this interpretative excess is perhaps emblematic of different processes operating in our interpretations of dramatic texts and theatrical scenes: first, Forman synesthetically attributes to the effects of words what we have actually seen and vice versa; second, he attributes to the thanes' reactions as characters in the play what is actually his own reaction as spectator of it, thus misconstruing the differences between their knowledge and his knowledge of Macbeth's secrets. A magma of words, gestures and actions on the one hand, and a bundle of readings, impressions and perceptions, on the other,

\footnotetext{
${ }^{28}$ Simon Forman, Booke of Plaies (Bodleian Library MS. Ashmole 208, fols. 207 ${ }^{\mathrm{r}-\mathrm{v}}$ ), quoted in Braunmuller, ed. (1997:58). On early Globe performances and Forman's account, see Bartholomeusz: "The reactions observed, fear, the impulse to retreat, and fury, the impulse to attack, indicate that the Elizabethan actor was bringing complex feelings to the surface" (1969:8).

${ }^{29}$ Macbeth's description of his own face must have also aided to form Forman's impression: "When now I think you can behold such sights / And keep the natural ruby of your cheeks, / When mine is blanched with fear" (3.4.115-117).
} 
constitute the stuff that make up a soul, or better, what we can aspire to know of it. And here lies perhaps the ultimate meaning of Duncan's "mind's construction," whose counterpart is not so much the "face" as it is the "mind" itself. In addressing the difference between the mind and the mind's construction -not only what the mind is made of but also and primarily what we can construe or make of it- Shakespeare, like Vives, acknowledges that, confronted by the inscrutability of its ultimate essence, man should proceed to an understanding of the self through the incomplete aid of indices and functions.

\section{The Divine, the Physician and the Critic: Minds, Bodies, Texts}

"Observe Also how Mackbetes quen did Rise in the night in her slepe, \& walke and talked and confessed all, \& the docter noted her wordes" (Forman, in Braunmuller 1997:58). Forman's memories of the play's performance raise a few questions if we rely on the only authoritative extant text of Macbeth. The fifth act opens with the Scottish Queen walking in her sleep under the attentive scrutiny of her maidservant and a doctor:

DOCTOR You see her eyes are open.

GENTLEWOMAN Ay but their sense are shut.

DOCTOR What is it she does now? Look how she rubs her hands.

GENTLEWOMAN It is an accustomed action with her, to seem thus washing her hands: I have known her continue in this a quarter of an hour. (5.1.23-26)

In keeping with the play's logic, the Queen's looks and gestures remain to her observers' eyes imperfect keys to her inner mystery. Such imperfection lies in the obliqueness of Lady Macbeth's action, whose continuous hand-rubbing metonymically replaces handwashing, a gesture which points literally to the concealment of proof -Macbeth's bloody hands in the second act- and implies symbolically the desire to purge the soul of murderous guilt: "this my hand will rather / The multitudinous seas incarnadine, / Making the green one red" (2.2.263-265). The Queen's wide-open eyes are perhaps a more complex issue: what the observers perceive here is a disentanglement of the organ -"eyes"- from its function "sense"- as materialized in the displacement from literal -"open"- to 
metaphorical -"shut." But the text may not restrict its focus to moral collapse through the psychological gap opened in the self between the functions of a controlling organism and its rebellious organs. The scene also points to another gap between self and other, materialized in the observer's attempt to gain true access to the interstices of someone else's inner self. We may be less prone to read "sense" as the truth of the Queen's soul, which is hinted at, though not fully explained, by her wide-open eyes. The eyes' "sense" is also "shut" to the observers' understanding. We are thus put on two different tracks: on the one hand, the failures of self-awareness understood as knowledge of one's own affects and intents; on the other, the inability to interpret signs as indices to others' inner selves. ${ }^{30}$

However, as Lady Macbeth speaks, her partial revelations of murder start to round off the "sense" advanced by her indexical gestures. The Doctor's reaction reveals him to be a shrewder psychologist than a physician: "Hark, she speaks, I will set down what comes from her, to satisfy my remembrance the more strongly" (5.1.38-29). The movement is not only from gesture to word: "besides her walking and other actual performances, what at any time have you heard her say?" (5.1.10-11). It also concerns a rendition of oral into written language -i.e. "set down"- as firmer ground for further interpretation. "Remembrance" of "actual performances" through writing will be certainly stronger than mere recollections of impressions derived from words and gestures - a procedure that should not surprise any Shakespeare critic.

The Doctor's conclusions, albeit refusing to reveal any explicit "sense," seem to leave no doubt: "infected minds / To their deaf pillows will discharge their secrets. / More she needs the divine than the physician" (5.1.62-64). In the context of early modern psychology, the soul's disturbance could be the effect of a literal, i.e. physical, "infection" of the brain or any other organ, as attested by the belief in the workings of the four bodily humours, and more

\footnotetext{
$3^{30}$ This may also apply to Macbeth's words to the Ghost of Banquo: "Thou hast no speculation in those eyes / Which thou dost glare with" (3.4.95-96). Speculation is certainly vision or sight, or even as the Oxford editor Nicholas Brooke suggests, "comprehending vision" (1990:158n). But the Ghost's lack of vision seems to suggest Macbeth's faulty "speculation," that is, his own inability to infer meaningfulness from the Ghost's face.
} 
specifically, in the effects of melancholia. ${ }^{31}$ But the Doctor's words cancel out that explanation in Lady Macbeth's case. Even his later diagnosis of "thick-coming fancies / That keep her from her rest" (5.3.39-40) conceives the thickness of the Lady's mind more as a metaphor than as any real pollution of the Lady's brains. The Doctor's phrasing of the Queen's malaise certainly seems to countervail her own invocation earlier in the play of the physical materiality of "spirits" that can "make thick" her "blood" and "stop th'access and passage to remorse" (1.5.38,40,41). Macbeth's own words to the Doctor are a desperate cry for a physiological answer to the riddle of his wife's obscure passions:

[...] Cure her of that.

Canst thou not minister to a mind diseased,

Pluck from the memory of a rooted sorrow,

Raze out the written troubles of the brain,

And with some sweet oblivious antidote

Cleanse the stuffed bosom of that perilous stuff

Which weighs upon the heart? (5.3.40-46)

Macbeth's insistence is on physical matter: that is, on the "stuff" whose weight clots his wife's "heart" and "stuffed bosom," and on the "antidote" that will rinse out her heavy infection. Even a "rooted" passion could be, in the King's act of wishful thinking, materially "plucked" from the "brain," as if sorrow were made of "written" traces conferring a tangible existence upon the Lady's corporeal memory. Macbeth wishes there were written marks on the surface of our organs showing our passions. Against this stubborn adherence to matter, the Doctor believes in writing only as a meaningful but imperfect sign system to aid his memory from his ready pocket notebook. His final verdict is also corrective of Macbeth's materialist expediency: "Therein the patient / Must minister to himself" (5.3.46-47; my emphasis). The adverb makes clear the inwardness of Lady Macbeth's secret "sense." Whatever the essence of the self-administered remedy recommended by the

\footnotetext{
${ }^{31}$ Bright's description of unnatural melancholy rising up to the brain by "adustion" or excessive heat is just one instance of a commonplace in early modern treatises: "For becomming more subtile by heate, both in substance, \& spirit, it passeth more deeply into all the parts of the instrument it selfe, and is a conueyance also to the humour of the same kind: making away for naturall melancholie, wherewith it is mixed, into the verie inward secrets of those instruments, whose passions are affected, euen heart and braine" (1586:111).
} 
Doctor, its intellectual or spiritual nature is in stark contrast with the very materiality of the "sweet oblivious antidote" desired by Macbeth. And yet the Doctor cannot look "therein:" he can simply surmise inward "sense" from the outward show of the Lady's gestures and words. As we compare the Doctor's sentence with Hamlet's "that within that passeth show" -which, in spite of very recent readings, continues to be paradigmatic of Shakespeare's focus on a hardly accessible human inwardness- we can conclude that, from the perspective of a qualified other, Lady Macbeth's "that within" will out only partially and with the aid of qualified interpreters of her "performances." ${ }^{2}$

The Doctor scenes in Macbeth might suggest different levels of looking into the play's "stuff." The first remains within the realm of character. Macbeth's figuration of the stuff inside his wife's body looks like a refusal to see the true "sense" in her soul. When earlier in the play Lady Macbeth qualifies ironically her husband's hallucinatory visions of the "air-drawn dagger" and the ghost of Banquo as "proper stuff," the effect might be quite similar, since the phrase suggests her complaint at Macbeth's refusal to deal with the materiality of the world around him -the dinner, his guests, his newly acquired throne and crown- and his surrender to immaterial visions: "this is the very painting of your fear" $(3.4 .62,60,61) .{ }^{33} \mathrm{In}$ both moments of the play the audience will perceive something wrong (here intended in a logical sense only) in the materialism invoked by both King and Queen. On the other hand, the Doctor redirects our considerations of matter to a more figurative sense. These relations linking matter and spirit, body and soul, will allow us to use the former as partially reliable guides to the latter, since, and despite the Renaissance belief in their contiguity, the inner self was seen as elusive of physical substance.

At a different level, the "stuff" in Macbeth becomes paradigmatic of two forms of critical understanding of Shakespeare's representation of the passions. Recent approaches to early modern literature's treatment of emotion have resorted to labels such as "cultural history" or "historical phenomenology" to stress the

\footnotetext{
${ }^{32}$ See in this sense footnote 2 above for contending readings of this line in Hamlet.

${ }^{33}$ Crawford points to the other uses of "stuff," especially in the tragedies and late romances, "in a subjective sense, for the things of the mind or spirit" (1915:159).
} 
importance of pre-Cartesian theories of the humoural body in cultural figurations of human affections. In words of Gail Kern Paster that specifically address Shakespeare's plays, "dramatic narratives of passion take place in an imagined physical and physiological environment epistemically prior to postEnlightenment dualism" (Paster 2004:244). ${ }^{34}$ I take Paster's work as representative of a decidedly radical challenge to interpretations of the early modern subject in terms of dualisms of body and soul. Against alleged post-Cartesian habits of imagining separate realms for passion and reason, body and soul, psychic and physiological processes and states, Paster's study means to redirect our looks to "the overarching unity of physical and psychological in early modern behavioral theory" (2004:76). Her aim is to restore our abilities to read early modern representations of the passions in their embodied materiality, and to encourage an interpretation of the early modern expression of the passions that will shun the risk of reading "abstraction and bodily metaphor" where "materiality and literal reference" to the body are meant (2004:26). In stark contrast, earlier studies on the Renaissance passions, while acknowledging the importance of the physiological basis of Renaissance psychology, are equally emphatic as to the early modern understanding of a dual nature of humankind whose invention is far from being as late as Descartes. Paul H. Kocher, a representative of a line of research into the cultural history of the Renaissance that some associate with "old historicism," calls the psychological dyad of body and soul "the great Elizabethan dualism" (1953:305), and traces the often contradictory accounts, divided between ascribing cause, effects, and processes to body and soul, of the passions and psychological ailments as found in Renaissance writers. His work serves here as instance of a prolific but unfairly neglected critical school. ${ }^{35}$

Kocher sees the psychological interest in the passions as trapped within the irreconcilable quarrels between medical science and religion. For the Renaissance psychologist "the question was not so much the human relationship to God as what man was in himself,

\footnotetext{
${ }^{34}$ Another study following a similar line of thought is Schoenfeldt, who nevertheless acknowledges that the early modern focus on physiology can be explained by its discursive ability "to render inwardness tangible" (1999:38).

${ }^{35}$ Campbell (1930), Craig (1952), Bamborough (1952), and Soellner (1972), are perhaps the most relevant examples for the purposes of this paper.
} 
what were the parts or faculties of his inner mechanism, how he thought, felt, remembered, willed, and whether these processes moved freely or were impeded by some malady" (Kocher 1953:306). For that reason, "the basic need of psychologists was to see the human being as an order functioning steadily and understandably. To them man must be an organism which, though partly inside (as body) and partly outside (as soul) the system of strictly natural laws, yet worked by principles of its own and was at least not supernatural" (Kocher 1953:313). The psychologist for his part lent the theologian the "whole concept of what the several faculties of the soul were and how they synchronized in the organism" (319).

Kocher's thesis was implemented by his later paper on the Doctor scenes in Macbeth published in the 1950s, some of whose points I have made mine in the above paragraphs. In Kocher's argument, it is the Doctor himself that acknowledges the incompetence of medicine in matters of sin. The play evinces the tensions between the stances of science and religion. While the Macbeths strive to persuade themselves of the material origin of their passions, the Doctor's statement emphasizes the spiritual, religious dimension of the problem of the soul's torment as caused by remorse. "It is not," Kocher argues,

that Shakespeare, of all men, fails to see the interaction of body and soul. But to have allowed the Doctor any competence whatsoever in the treatment of Lady Macbeth would have been to obscure the dramatic point he wished to make. And this point, it will bear repeating, was that the source of all her ills was neither natural melancholia nor madness but solely conscience. (1954:345)

Critical interpretation is often the result of critical method, and the two parties reviewed here certainly sustain methodological comparison. In her account of the passions, Paster's procedure throughout her book-length study is to look for, through the examination of "discrete moments and locutions in the play texts" of Shakespeare, "evidence for investigating the phenomenological character of early modern emotion and to contextualize that evidence through reference to early modern treatises, medical texts, natural history, and other literary works" (Paster 2004:23). In stark contrast, Kocher's reading seeks "deep dramatic relevance for the meaning of the play as a whole" -with all the implications this statement has for the understanding of character, plot and intention (1954:349). Reliance on the relevance of discrete moments versus 
attempts at integral readings of plays explains the different conceptions of the early modern self emanating from Paster's and Kocher's work. Kocher insists on the Renaissance writers' idea of an organism aspiring to integral functioning and order but exposed to the vicissitudes of bodily disorder, external action, and sin. Paster emphasizes the absence of an integral self, a notion that is conceptually close to post-modern delineations of the subject like Deleuze and Guattari's BwO (i.e. "Body without Organs"). Thus in Pyrrhus "roasted in wrath and fire," as put by the First Player's tale in Hamlet (2.2.461), Paster suggests that we see "an embodied subject spilling beyond the boundaries of organized selfhood, a subject more like a material site, an intensity of desiring matter or its vacuous absence" (2004:43).

Suggestive as Paster's method and conclusions are, one wonders to what extent an almost exclusive focus on the physiological experience of passionate processes does justice to early modern representations of affect. One may also question an analytical method based only on discrete moments and isolated phrases against more integral considerations of theatrical scripts. In these choices of focus and method one detects a bias against theoreticizing an inner organic consciousness, or against its literary representation in consistent dramatic individualities reclaiming the possession of a distinct inner self not only subjected to unstable emotional outbursts but also capable of aspirations to selfknowledge and self-awareness. I agree with a representation of early modern passions as hardly separable from physiological processes. But this essay resists a reading of early modern dramatic selves as easily reducible to post-modern bodies without organs. Shakespeare might have been wrong when determining in Macbeth that the Queen's mystery would be better unravelled by a divine than a physician. But by doing so he did justice to worldviews current in his time. As a late humanist turning to scepticism and as a tragic dramatist, he also understood that on the stage a physician failing to find out Lady Macbeth's problem was far more effective than a theologian trying to solve it. Shakespearean tragedy portrays a world abandoned by God, but a world nevertheless where humans still believe that this distant God may have the answer to their mysteries. The Doctor in Macbeth is the character that best understands, like Vives and like many others, that, deprived of knowledge of their own ultimate essence as humans are, those 
things called the mind and soul need to be grasped by indirections and intuitions.

\section{Coda: The Visage in the Mind}

In the first act of Othello (1605), Desdemona explains her falling in love with her husband in words that stand as a photographic negative of this paper's argument: "I saw Othello's visage in his mind" (1.3.252). If Duncan fails to find the mind's construction in Cawdor's face, Desdemona thinks she has succeeded in finding Othello's true face in his mind's construction. Her procedure is certainly a surprising one, and not only for all it implies in terms of the racial complexities of the play. Her conviction that Othello's inner self becomes a mirror to his true face suggests that human modes of awareness cannot be disentangled from the passions under whose influence human beings think, feel and act. As imaginative experience, her construction of "Othello's visage" is, like Macbeth's illusion of the "air-drawn dagger," a certain index to her passion's "proper stuff." The extent to which Othello may be a rhetorical exercise in undoing Desdemona's initial construction of her husband's face and mind goes to show that in Shakespearean tragedy the voyage from inward self to outward show can prove as problematic as its opposite. Findings and losses in both directions prove that the unreliable nature of our modes of awareness is due to the gap between our will to know and the partiality of its discoveries.

\section{References}

Aers, David 1992. "A Whisper in the Ear of Early Modernists: or, Reflections on Literary Critics Writing the "History of the Subject.'” Ed. David Aers. Culture and History 1350-1600: Essays on English Communities, Identities and Writing. London: Harvester: 177-202.

Aristotle 1926. Art of Rhetoric. Ed. and trans. J. H. Freese. Cambridge, Ms.: Harvard University Press.

Bamborough, J. B. 1952. The Little World of Man. London: Longmans, Green, and Co., 1952.

Barker, Francis 1984. The Tremulous Private Body: Essays on Subjection. London: Methuen. 
Bartholomeusz, Dennis 1969. Macbeth and the Players. Cambridge: Cambridge University Press.

Baumbach, Sybille 2008. Shakespeare and the Art of Physiognomy. Penrith: Humanities-Ebooks.

Bright, Timothy 1586. A Treatise of Melancholie. London: Thomas Vautrollier.

Camden, Carroll 1941. "The Mind's Construction in the Face." Philological Quarterly 20/3: 400-412.

Campbell, Lily B. 1930. Shakespeare's Tragic Heroes: Slaves of Passion. London: Methuen.

Cefalu, Paul 2004. Revisionist Shakespeare: Transitional Ideologies in Texts and Contexts. New York: Palgrave Macmillan.

Cicero, Marcus Tullius 1577. Four Several Treatises. Trans. Thomas Newton. London.

Cicero, Marcus Tullius 1942. De Oratore. Ed. and trans. H. Rackham. Cambridge, Ms.: Harvard University Press.

Colish, Marcia L. 1962. "The Mime of God: Vives on the Nature of Man." Journal of the History of Ideas 23/1: 3-20

Craig, Hardin 1927. "A Contribution to the Theory of the Renaissance." Philological Quarterly 6: 321-333.

Craig, Hardin 1975 (1952). The Enchanted Glass: The Elizabethan Mind in Literature. Westport: Greenwood Press.

Crawford, A. W. 1915. "O proper stuff! - Macbeth, III, iv, 6o." Modern Language Notes 30/5: 158-160.

Davies, John 1599. Nosce Teipsum. London: Richard Field.

Diehl, Huston 1983. "Horrid Image, Sorry Sight, Fatal Vision: The Visual Rhetoric of Macbeth." Shakespeare Studies 16: 191-204.

Doran, Madeleine 1954. Endeavors of Art: A Study of Form in Elizabethan Drama. Madison: University of Wisconsin Press.

Elam, Keir 1996. "'In What Chapter of his Bosom?': Reading Shakespeare's Bodies." Ed. Terence Hawkes. Alternative Shakespeares, vol. 2. London: Routledge: 140-163.

Florio, John 1598. A World of Words. London: Arnold Hatfield.

Freud, Sigmund 1977 (1916). "Some Character-Types Met with in Psychoanalytic Work." Writings on Art and Literature. Stanford: Stanford University Press: 151-175.

Headlam Wells, Robin 2005. Shakespeare's Humanism. Cambridge: Cambridge University Press.

Hill, Thomas 1571. The Contemplation of Mankind. London. 
Holinshed, Raphael 1586. The Second Volume of Chronicles. London.

Jonson, Ben 1966 (1599). Every Man in His Humour. Ed. Martin SeymourSmith. London: Ernest Benn.

Joseph, B. L. 1951. Elizabethan Acting. London: Oxford University Press

Kerrigan, William 1996. "Macbeth and the History of Ambition." Ed. John O'Neill. Freud and the Passions. University Park: University of Pennsylvania Press: 13-24.

Kirsch, Arthur 1972. The Passions of Shakespeare's Tragic Heroes. Charlottesville: University Press of Virginia.

Kocher, Paul H. 1953. Science and Religion in Elizabethan England. San Marino, Ca.: Huntington Library.

Kocher, Paul H. 1954. "Lady Macbeth and the Doctor." Shakespeare Quarterly 5/4: 341-349.

Machiavelli, Niccolò 1640. The Prince. Trans. Edward Dacres. London.

McDonald, Charles Osborne 1966. The Rhetoric of Tragedy: Form in Stuart Drama. Amherst: The University of Massachusetts Press.

Maus, Katharine Eisaman 1995. Inwardness and Theater in the English Renaissance. Chicago: The University of Chicago Press.

Nonius Marcellus 2003. De compendiosa doctrina. Ed. Wallace M. Lindsay. Munich: Saur.

Paster, Gail Kern 2004. Humouring the Body: Emotions and the Shakespearean Stage. Chicago: The University of Chicago Press.

Paster, Gail Kern, Katherine Rowe, and Mary Floyd Wilson eds. 2004. Reading the Early Modern Passions: Essays in the Cultural History of Emotions. Philadelphia: University of Pennsylvania Press.

Peacham, Henry 1577. The Garden of Eloquence. London.

Quintilian 1921. Institutio Oratoria. Ed. and trans. H. E. Butler. Cambridge, Ms.: Harvard University Press. 3 vols.

Rossky, William 1958. "Imagination in the English Renaissance: Psychology and Poetic." Studies in the Renaissance 5: 49-73.

San Isidoro de Sevilla 1982 (c. 615). Etimologías [Etymologiarum libri]. Ed. José Oroz Reta and Manuel A. Marcos Casquero. Madrid: Biblioteca de Autores Cristianos.

Schoenfeldt, Michael C. 1999. Bodies and Selves in Early Modern England: Physiology and Inwardness in Spenser, Shakespeare, Herbert, and Milton. Cambridge: Cambridge University Press.

Shakespeare, William 1972 (1601). Hamlet. Ed. Harold Jenkins. London: Methuen. 
Shakespeare, William 1997 (1606). Macbeth. Ed. A. R. Braunmuller. Cambridge: Cambridge University Press.

Shakespeare, William 1990 (1606). Macbeth. Ed. Nicholas Brooke. Oxford: Oxford University Press.

Shakespeare, William 1984 (1605). Othello. Ed. Norman Saunders. Cambridge: Cambridge University Press.

Shakespeare, William 1985 (1602). Twelfth Night. Ed. Elizabeth Story Donno. Cambridge: Cambridge University Press.

Sherry, Richard 1550. A Treatise of the Figures of Grammer and Rhetorike. London: Richard Tottel.

Sidney, Philip 1931 (1591). Astrophel and Stella. Ed. Mona Wilson. New York: Nonesuch Press.

Soellner, Rolf 1972. Shakespeare's Patterns of Self-Knowledge. Columbus: Ohio State University Press.

Taylor, Charles 1989. Sources of the Self: the Making of Modern Identity. Cambridge: Cambridge University Press.

Thomson, Peter 1997. "Rogues and Rhetoricians: Acting Styles in Early English Drama." Ed. John D. Cox and David S. Kastan. A New History of Early English Drama. New York: Columbia University Press: 321-335.

Vives, Juan Luis 1612 (1531), De disciplinis. Hi de Curruptis Artibus Doctissimi viri notis, illi de tradendis Disciplinis cuiusdam Studiosi Oxoniensis annotationibus illustrati. Cum indice copioso. London.

Vives, Juan Luis 1782. De anima et vita. Opera Omnia, Tomus III. Ed. Gregorio Mayans. Valencia.

Vives, Juan Luis 1913. On Education: a Translation of the De tradendis disciplinis. Trans. Foster Watson. Cambridge: Cambridge University Press.

Whitney, Geffrey 1997 (1586). A Choice of Emblems. Ed. Peter Daly. The English Emblem Tradition. Index Emblematicus. Vol. 1. Toronto: The University of Toronto Press.

Wright, Thomas 1604 (1601). The Passions of the Minde in Generall. London: Valentine Simmes.

How to cite this article:

Luis Martínez, Zenón. "Macbeth and the passions' "proper stuff"." SEDERI 20 (2010): 71-101.

Author's contact: luis@uhu.es

Submission: 23/02/2009

Acceptance: 02/07/2009 


\title{
The French Influence on Early Shakespeare Reception in Spain: Three Cases of Unacknowledged Sources
}

\author{
Ángel-Luis Pujante \\ Universidad de Murcia
}

\begin{abstract}
Shakespeare criticism in Spain began in 1764 and has been on the increase ever since. The main source of information on the subject has long been the tremendous work done by Alfonso Par from the beginning of the 2oth century until his death in 1936: without his Shakespeare en la literatura española (1935) none of the later studies could have been written, or at least they would have taken a good deal longer to write. On the other hand, Par's book includes gaps and errors which need to be corrected. Among these are three cases of supposedly original texts which have turned out to be appropriations of foreign originals whose sources were not acknowledged. This article sets out to analyze these cases, examine their critical implications and thus contribute to a better knowledge and understanding of the Spanish reception of Shakespeare.
\end{abstract}

KEYWORDS: Shakespeare, Shakespeare criticism, Shakespeare reception, literary history, comparative literature.

I Shakespeare came to Spain in the $18^{\text {th }}$ century, not directly from England, but via France. He arrived as the monster created by

\footnotetext{
* This paper is part of Research Project FFI2008-01969/FILO, funded by the Spanish Ministry of Science and Innovation. The unacknowledged sources dealt with in this article were spotted in the course of the research carried out both for this project and for the previous one on the same subject ("The presence of Shakespeare in Spain in the framework of his European reception", HUM-2005-02556/FILO). I am particularly grateful to Michèle Willems for drawing my attention to the "Parallèle entre Shakespear \& Corneille," not mentioned in Jusserand (1889) or Pemble (2005).
} 


\section{A. L. Pujante}

Voltaire, bringing with it the controversy about his vices and virtues. The first Spanish critical text dealing with Shakespeare (1764), that of Mariano Nifo, involves the French neoclassical view of him and contains Voltaire's opinion of the French conception of tragedy as opposed to the English concept. From Nifo onwards and for several decades, most Spanish writers on Shakespeare joined the debate and took sides, the neo-classicists being critical of him, and the traditionalists (supporters of Lope de Vega and Calderón), in favour of him.

Critical interest in Shakespeare reception in Spain began with Daniel López's "Shakespeare en España" (1883), which contained a plentiful list of productions of Shakespearean adaptations between 1772 and 1838 and reflected the various responses to neoclassical adaptations, with particular attention to the translations used and the taste of the audiences. Going beyond performance, more wideranging studies followed, those of Eduardo Juliá (1918) and Ricardo Ruppert (1920), and, above all, the long and patient work of Alfonso Par, which culminated in his Shakespeare en la literatura española (1935). It is surprising that this Catalan businessman should have had such an interest in Shakespeare as to devote himself so wholeheartedly to his Spanish reception, spending three decades gathering such a huge amount of information, some of which was then rather hard to come by. Later students of the subject are therefore indebted to this extensive documentation which has made the continuation of his efforts an easier task. In fact, Shakespeare reception in Spain both in general and in its early manifestations, has been taken up forcefully since around 1990, as shown in a large number of relevant publications. ${ }^{1}$

However, Par's book includes a number of gaps and errors which need to be corrected. Here I shall focus on three critical texts considered by Par to be Spanish original articles but which have turned out to be translations of foreign texts whose source and authorship are not acknowledged by the authors of the three articles. One of them presents all the characteristics of plagiarism, as expressed in the definition given in the OED: "The wrongful

\footnotetext{
${ }^{1}$ For the early reception, see among others Calvo (2002, 2006, 2008); Deacon (1996); Gregor (2002, 2003, 2010); Kerson (1989a, 1989b); López Román (1988, 1989, 1993); Moro (1996); Pujante (1999, 2001a, 2001b, 2005, 2006, 2008); Pujante \& Campillo (2007); Pujante \& Gregor $(2005,2008)$; Verdaguer (2004).
} 
appropriation or purloining, and publication as one's own, of the ideas, or expression of the ideas (literary, artistic, musical, mechanical, etc.) of another." The other two cases may be different, but if they cannot be accused of wrongful appropriation, their wrongful uses are obvious. I shall deal with the three independently, though for the sake of methodological convenience a strictly chronological order will not be followed. At the same time, and in order to avoid misunderstandings, let it be stated from the outset that judicial accusation or judgement is not the purpose of the article, and that Par could only be held responsible for the errors and omissions in dealing with these three cases.

2 Discussing Spanish critical texts written in praise of Shakespeare at the beginning of the 19th century, Alfonso Par (1935:154-156) mentions an article by one G. Romo entitled "Paralelo entre Shakespeare y Corneille," published in a 1806 issue of Memorial Literario. In it, the author compares Shakespeare and Corneille without neoclassical prejudice and declares Shakespeare's superiority over the French playwright. For Par, this is "the first Spanish voice since Cadalso which rises with determination to elevate the British dramatist." ${ }^{2}$

However, Par did not know or suspect that the Romo article was in fact a translation of "Parallèle entre Shakespear \& Corneille," published anonymously in the Journal Encyclopédique in October 1760. The preference for Shakespeare over Corneille in France at that time can be accounted for by the rampant French Anglomania, which, according to J.J. Jusserand (1899:274), was also responsible for other similar writings in which Shakespeare was preferred to Corneille. Besides being an anonymous publication, this "parallèle" was not presented as an original contribution but as "traduit de l'Anglois." This can be explained by the fact that this French Anglomania had not displaced Neoclassicism, still very much alive in France, so one can understand that the author decided to pass off his article as "translated from the English" in an attempt to exempt

\footnotetext{
2 "La primera voz española que desde Cadalso se alza decidida para encumbrar al dramaturgo británico" (Par 1935:154). All the translations from the Spanish and French are my own.
} 


\section{A. L. Pujante}

himself (and any other French writer) from expected adverse neoclassical reactions.

Be that as it may, Romo appropriated the French article by translating it almost word for word and publishing it as his own with a few personal alterations. The following parallel quotations will suffice to show the extent of the appropriation -with Romo's additions emphasized in italics.

French original

Shakespear \& Corneille sont les deux plus grands génies que le Théatre Anglois \& le Théatre François ayent jamais eus. Il se trouve entre ces deux grands Poëtes des traites de ressemblance qui sont frappans. Corneille été le Pere de la Poësie dramatique en France; Shakespear en Angleterre. [...] Mais toutes les Tragédies de Shakespear roulant sur des sujets tout-à-fait différens les uns des autres, il n'est pas possible de trouver la moindre ressemblance entre les plans de Kinglear, de Hamlet, d'Othello, de Jules César, \& de Romeo. L'infortune de Kinglear est fondé sur les malheurs d'un pere; celle de Hamlet sur ceux d'un fils; celle d'Othello sur ceux d'un mari jaloux. [...] En un mot, on diroit que Shakespear a trop de génie pour s'assujetir aux régles du théâtre, \& que Corneille, s'il eut été un gran génie, $s^{\prime} y$ seroit moins asservi. [...]

\section{Romo's text}

Guillelmo Shakespeare y Pedro Corneille son los dos mayores ingenios que han producido los teatros ingles y frances. En los dos notamos acciones tan parecidas, y al mismo tiempo tan opuestas que verdaderamente causan admiración. Corneille ha sido el padre ó creador de la poesía dramática en Francia: Shakespeare lo ha sido igualmente en Inglaterra. No así las tragedias de Shakespeare; todas giran sobre objetos diferentísimos unos de otros; y así no es posible hallar la menor semejanza entre los planes del Rey Lear, de Hamlet, de Otelo, de Julio Cesar y de Romeo. La catástrofe del Rey Lear se funda sobre las desgracias de un padre, la de Hamlet sobre las de un hijo, la de Otelo sobre las de un marido celoso. En una palabra, diremos con uno de nuestros mejores literatos que Shakespeare tenía demasiado ingenio para sujetarse á las reglas del teatro, y que Corneille se hubiera sujetado aún menos si hubiera tenido mayor ingenio.

Romo effected various changes. He omitted a sentence in the original where Shakespeare is called "the mirror of Nature," replaced the last paragraph, in which new parallels are announced, 
with another in which Romo informs the reader of new, forthcoming parallels, and added four informative footnotes that were not in the French article. As for his addition at the end of the above quotation, to the effect that one of "our best writers" holds the opinion that Shakespeare was too much of a genius to subject himself to rules, Romo refers to Moratín in a footnote, and particularly to what he wrote in the prologue and "Life of Shakespeare" preceding his translation of Hamlet (1798). However, this is not what Moratín wrote. On the contrary, he was a staunch neoclassicist who kept proclaiming the need for the rules till the end of his life. After seeing Julius Caesar performed in London, he jotted down: "such an irregular play, dictated only by genius and without the aid which art can lend." ${ }^{3}$ And in "Life of Shakespeare" referred to by Romo, what he actually wrote was:

Such plays, even if they contain excellent fragments, will only help to perpetuate the corruption of taste and, if we end up admitting the maxim that a genius should not submit to scientific precepts and that it is not lawful to examine those great men, disciples of nature, fertile and uneducated as the original they imitated, there is no way: this opinion, once established, will be the ruin of the arts. ${ }^{4}$

As Par makes clear (1935:1.155), the Spanish article was severely challenged in the same Memorial Literario a month later in the article "Reflexiones acerca del paralelo entre Shakespeare y Corneille [...]," by one "J.S.C.", who, after praising Corneille, violently attacked Shakespeare. Clearly, J.S.C. did not know that the "Paralelo" was actually the Spanish rendering of a 1760 French original -with all that this implied, as will be discussed later- and assumed that Romo himself was the author. (Incidentally, J.S.C. quotes a 1773 Essai sur

\footnotetext{
3 "Una pieza tan irregular, dictada sólo por el ingenio y sin los auxilios que presta el arte" (Moratín 1867-1868:179).

4 “Tales obras, aunque contengan pedazos excelentes, servirán solo de perpetuar la corrupcion del gusto; y si llega á admitirse la máxîma de que el ingenio no debe sujetarse á los preceptos científicos, y que no es lícito exâminar á aquellos grandes hombres, discípulos de la naturaleza, fecundos é incultos como el original que imitaron: no hay medio, esta opinion acreditada una vez, será la ruina de las artes" (Celenio [Moratín] 1798:n.p.).
} 


\section{A. L. Pujante}

l'art dramatique "by a famous writer," who proclaimed that Corneille "[...] has been and will be the favourite of great souls for all ages"). ${ }^{5}$

Romo was clearly at fault for appropriating someone else's article and ideas without quoting his sources, to the extent of signing it as his own and thus leading critics like Par to believe it was his. To his credit he contributed to the reception of Shakespeare in Spain in sharing those ideas and taking sides in favour of Shakespeare, to the point of even manipulating Moratín's opinion to his own advantage.

3 In the section on Shakespeare reception in the Spanish Romantic period, Alfonso Par presents the "venerable figure of Antonio Bergnes", a Catalan professor of Greek, critic and translator, who "dealt with Shakespeare in his journal El Museo de Familias" (1935:331-332). Par discusses two unsigned articles that he attributes to Bergnes: "Shakspeare" (1839), and "Comparación entre las literaturas de los diversos países del globo" (1840). In "Shakspeare", on which I shall concentrate here, Par praises the author's interpretation of the character of Hamlet and, among other things, mentions Bergnes' complaint that the Spaniards did not manage to represent the episodes of the Reconquista as Shakespeare did in his history plays. Par concludes that Bergnes' is a "notable" study, revealing "a good knowledge of the English commentators of the time, as well as personal critical independence." ${ }^{\prime 6}$

Par attributed the Shakespeare article to Bergnes -as he did the 1840 article- because he knew that he was the editor of El Museo de Familias, thus taking for granted that, since the 18th century, most of the articles in such relatively popular journals were the work of the editors themselves, who often published them anonymously. Elsewhere the journal acknowledged a collaboration, thanked the collaborator by name, and invited more such publications (1839:II.302). Nevertheless, "Shakspeare" was not an original article by Bergnes, as Par must have thought, but an almost literal translation of "Essai biographique et littéraire sur Shakspeare" (1838)

\footnotetext{
5 The writer in question, not named by J.S.C., was Louis-Sébastien Mercier. The original French quotation reads: "a été \& sera dans tous les tem[p]s le favori des grandes âmes" (Mercier 1773:220).

6 "Buen conocimiento de los comentaristas ingleses de su tiempo, al par que independencia crítica personal" (Par 1935:335).
} 
by the writer, politician and professor Albert-François Villemain (1791-1870), which was later variously reprinted. The following parallel quotations will suffice to show the real origin of the article.

French original

Shakspeare (William), l'homme de génie du théâtre anglais, naquit le 23 avril 1564, à Stratford sur Avon, dans le comté de Warwick. On sait fort peu de chose sur les premières années, et sur la vie de cet homme si célèbre; et malgré les recherches minutieuses de l'érudition biographique, excitée par l'intérêt d'un si grand nom, et par l'amour-propre national, les Anglais ne connaissent guère de lui que ses ouvrages. [...] Ben-Johnson, Fletcher et Beaumont, n'avaient ni plus ni moins d'art; mais souvent cheux eux cette excessive liberté 'amenait que des combinaisons vulgaires; et presque toujours ils manquent d'éloquence. Dans Shakespeare, les scènes brusques et sans liaison offrent quelque chose de terrible et d'inattendu. [...] La soif inextinguible de l'or, la cruauté avide et basse, l'âpreté d'une haine ulcérée par les affronts y sont tracées avec une incomparable énergie, et l'un de ces caractères de femme si gracieux sous la plume de Shakspeare répand dans ce même ouvrage, au milieu d'une intrigue romanesque, le charme de la passion. $[\ldots]$
Spanish text

Guillermo Shakespeare, á quien podemos llamar el rey del teatro inglés, nació el 23 de abril de 1564, en Stratford, a orillas del Avon, en el condado de Warwick. Se tienen muy pocas noticias de los primeros años de la vida de este hombre tan célebre; y á pesar de las minuciosas investigaciones de la erudicion biográfica, provocada por el interés que despierta un nombre tan ilustre, los Ingleses no conocen de él mas que sus obras. Ben Johnson, Fletcher y Beaumont no conocían ni más ni menos el arte; pero en ellos con frecuencia esta escesiva libertad no producia mas que combinaciones vulgares, y además carecian siempre de elocuencia. En Shakespeare hasta las escenas mas bruscas y sin enlace ofrecen algo de terrible e inesperado. Vense trazados en él con una enerjia inimitable la sed inestinguible del oro, la crueldad mas codiciosa y rastrera, la aspereza de un odio enconado por las afrentas; al mismo tiempo que uno de esos caracteres de mujer, tan graciosos bajo la pluma de Shakespeare, derrama en esta misma obra, en medio de una trama anovelada, el encanto de la pasión.

Like Romo, the editor here made some changes and adjustments. He did not translate a sentence in the original to the effect that Shakespeare depicts both the most tragic and the most 


\section{A. L. Pujante}

graceful in his characters, which he probably skipped through oversight. He also left untranslated the last paragraph and bibliographical notes in the original -devoted to Shakespeare scholarship and editions- presumably because it would have been excessive for a popular journal. Perhaps for a similar reason he omitted a reference to two characters in Voltaire's Zaïre and to the style of the poet Du Bellay. However, his other changes were in all probability effected to erase all traces of the original publication. Thus all French references were de-Frenchified: in the Spanish text "notre Corneille" and "notre Molière" become simply "Corneille" and "Molière"; "notre tragédie française", "la tragedia francesa"; "[le] grossier théâtre que nous avions", "[el] grosero teatro que tenían los Franceses".

But surely the most significant change also involves what is one of the most interesting observations in Villemain. As John Pemble puts it, Villemain, who had Shakespeare's history plays in mind, had complained that the French had no Shakespeare, no "literary genius who had nurtured a national memory and set hearts beating faster with a sense of purpose, possibility, and destiny" (2005:18). Therefore, in Villemain's words, they lacked a playwright capable of staging, giving his words a savage energy, "the revengeful deeds of Louis XI, the crimes of the palace of Charles IX, the audacity of the Guises, and the furious atrocities of the League," with the result that the French had no taste for their manners, "nor, above all, any portion of the enthusiasm of national patriotism" (cit. Pemble 2005:18). Faced with these French references, the Spanish editor replaced them with two from Spanish history ("the revengeful deeds of Pedro el Cruel, the wars against the Moors").

As far as Bergnes' appropriation is concerned, it had been customary for many such periodicals since the 18th century to incorporate all kinds of articles, notes and news from various foreign newspapers, particularly French (Saiz 1983:143), which were then translated and/or adapted by the Spanish editor and published anonymously without citation of the sources. On the other hand, there were others, like the Espiritu de los mejores diarios que se publican en Europa, whose editor, Cristóbal Cladera, controlled the quality and prestige of his newspaper, quoted his sources of information and offered a detailed description of the reviews, newspapers, articles and books he received (Saiz 1983:191). On the whole, 
however, it would seem that a number of editors and readers at the time did not pay much attention or attach much importance to such matters, so that an anonymous article could easily be attributed to the editor of the publication. This state of affairs also seems to have continued down to Alfonso Par's time, as we have seen, and may have encouraged other appropriations and/or wrongful uses in Shakespeare reception in Spain which we have not yet detected.

4 Discussing the reception of Shakespeare in Spain at the end of the 18th century, Alfonso Par (1935:105-106) mentions "Reflexiones sobre el teatro inglés," an essay by Joseph Calderón de la Barca, published in a 1797 issue of the Memorial Literario. Its author, whom Par refers to as the editor of the journal, expresses a rather critical view of Shakespeare. The source for all this information is Menéndez Pelayo's Historia de las ideas estéticas en España, whose comments on Joseph Calderón and his essay Par follows closely. However, Menéndez Pelayo has been corrected (Urzainqui 1990:508) to the effect that Calderón was not the editor of the journal but a very frequent collaborator. Par, therefore, follows his source in this mistake, as well as in the fact, not mentioned by Menéndez Pelayo, that the essay was published anonymously. However, neither the mistake nor the omission questions Calderón's authorship. Both critics mention that the author of the essay refers in a footnote to a previous article ("Carta apologética en defensa de Lope de Vega y otros poetas cómicos españoles"), published a year earlier in the same journal and signed J.M.C.B. (i.e. Joseph María Calderón de la Barca), in which Shakespeare is also criticised, thus making his hand in the 1797 essay highly probable, if not certain beyond doubt.

Commenting on the content of "Reflexiones sobre el teatro inglés," Par thinks that Joseph Calderón did not understand Shakespeare, and quotes what for him are surprisingly derogatory sentences revealing "aesthetic blindness." However, this Spanish essay was for the most part an almost literal rendering of Voltaire's 18th letter ("Sur la tragédie") and 19th letter ("Sur la comédie"), included in his Lettres philosophiques (1734). Let us look at these statements in the Spanish text set against the French original ("Sur la tragédie"): 
Voltaire

Il [Shakespeare] avait un génie plein de force et de fécondité, de naturel et de sublime, sans la moindre étincelle de bon goût. [...] Ja vais vous dire une chose hasardée, mais vraie: c'est que le mérite de cet Auteur a perdu le théâtre anglais; il y a de si belles scènes, des morceaux si grands et si terribles répandus dans ses Farces monstrueuses qu'on appelle Tragédies, que ces pièces ont toujours été jouées avec un grand succès. [...] La plupart des idées bizarres et gigantesques de cet auteur ont acquis au bout de deux cents ans le droit de passer pour sublimes. [...] Vous savez que dans la tragédie du More de Venise, pièce très touchante, un mari étrangle sa femme sur le théâtre, et quand la pauvre femme est étranglée, elle s'écrie qu'elle meurt très injustement. Vous n'ignorez pas que dans Hamlet des fossoyeurs creusent une fosse en buvant, en chantant des vaudevilles, et en faisant sur les têtes des morts qu'ils rencontrent des plaisanteries convenables à gens de leur métier. Mais ce qui vous surprendra, c'est qu'on a imité ces sottises. [...] On a laissé dans le Jules César de Shakespeare les plaisanteries des cordonniers et des savetiers romains introduits sur la scène avec Brutus et Cassius. [...] Le génie poétique des Anglais ressemble jusqu'à présent à un arbre touffu planté par la
Spanish text

[Shakespear] era hombre de un ingenio vehemente $\mathrm{y}$ fecundo, harto natural y sublime; pero sin la menor chispa de buen gusto [...] Me atrevo á decir que el mérito de este autor perdió el teatro Ingles: pues, conteniendo sus farsas monstruosas (que por mal nombre llaman tragedias) escenas admirables y acciones terribles, las tales piezas se han representado con sumo aplauso [...] Las ideas extravagantes y gigantéas de este autor han adquirido al cabo de 150 años derecho de pasar por sublimes. Bien sabido es que en la tragedia el Moro de Venecia, pieza á la verdad interesante, un marido ahoga a su mujer en el teatro, y después de muerta exclama que muere injustamente. En la tragedia Ham[l]et los mullidores estaban en una fosa bebiendo tragos, cantando xacaras y chuleándose con las calaveras que hallan en un lenguaje propio de su oficio; pero lo que me admira todavía mas es que hayan imitado tamañas necedades [...] Pero han dexado en Julio Cesar del mismo Shakespear chanzas pesadas de sastres y zapateros Romanos, que alternan en la escena de Casio y Bruto [...] El ingenio poético de esta nación es semejante a un arbol silvestre muy copado, que brota hácia todas partes con si suma fuerza. Muere si alguno intenta oprimir su naturaleza, y podarle como los árboles del retiro. 
nature, jetant au hasard mille rameaux, et croissant inégalement et avec force; il meurt, vous voulez forcer sa nature et le tailler en arbre des jardins de Marly.

The translation is virtually literal. Menéndez Pelayo -whom Par follows and paraphrases- observes that Joseph Calderón "repeated Voltaire's jokes" on the gravediggers in Hamlet, and he praises Calderón's "happy comparison" between the poetic genius of England and a wild leafy tree branching out forcefully in all directions (1886:III.2.157). However, as can be seen in the above quotations, Menéndez Pelayo does not seem to have noticed the literalness of Calderón's "repetition" of Voltaire's jokes, or to have realised that the "happy comparison" had previously been expressed by Voltaire.

Clearly, Par repeats Menéndez Pelayo's error. But there is more. As can also be seen at the end of the Spanish text in the above quotation, the wild tree to which the poetic genius of England is compared and which would die if pruned is like the trees in the Madrid gardens of the Retiro -these gardens having, therefore, replaced those of the French Marly palace in Voltaire. But in his quotation Menéndez Pelayo added "or of Versailles" ("ó de Versalles"). Why did he place this French reference after the Spanish one as an alternative? Was it because, after all, he knew the French original and therefore Voltaire's reference to Marly -the palace to which King Louis XIV wanted to move to get away from Versailles?

As it happens, Menéndez Pelayo had referred to Voltaire's 18th letter in the previous volume to the one in which he discussed the 1797 article: "[Voltaire] had discovered a treasure that he failed to exploit: Shakespeare's drama. How much amazement must have been produced by those Lettres anglaises, in which Hamlet's soliloquy appeared in translation for the first time!" ${ }^{\prime 7}$ And three pages later he added: "in the Lettres anglaises [Voltaire] had called Shakespeare 'a genius full of force, fecundity and sublimity, although without the least knowledge of the rules', and the tragedy of The Moor of Venice 'a

7 "[Voltaire] había descubierto un tesoro que no acertó á explotar: el teatro de Shakespeare. ¡Qué asombro debieron de producir aquellas Cartas sobre los ingleses, donde por primera vez apareció traducido el monólogo de Hamlet!" (1886:III.1.58). 


\section{A. L. Pujante}

very moving play'. $^{\prime \prime}{ }^{8}$ It should be clear that he had read Voltaire's letter, from which he cites in translation, albeit carelessly. ${ }^{9}$ But then, why did he praise Joseph Calderón and not Voltaire for the "happy comparison" between the poetic genius of England and a wild leafy tree? Perhaps, since he quoted Calderón's text and the comparison inaccurately - probably by heart or from badly taken notes, like his references to the Lettres anglaises- he did not realise the nature and origin of the 1797 article, or he did realise and preferred not to go into it.

Be that as it may, we are not dealing here with appropriations of sentences or of a single comparison, but of a significant portion of the 18th letter, so that the French writer's observations were consciously passed off as a Spanish author's "Reflexiones." In the first place, Joseph Calderón's translation skips Voltaire's rendering of the "to be or not to be speech" included in the letter, so that when Voltaire says that he has ventured ("hasardé") to translate it, the Spanish editor retains this, but leaps ahead to a speech by Dryden also translated by Voltaire which comes next and says he has tried ("intentado") to translate Dryden -even if he renders only the first four lines. The omission of the Shakespearean soliloquy clearly shows his purpose. Voltaire's translation of it in French rhymed couplets is deliberately poetic and free -he expressly curses the literal translators for weakening the sense by rendering it word for word (1964:107). It reads, therefore, rather differently from the blank verse speech in Shakespeare, so that translating the French instead of the English original would leave the article open to suspicion or clearly reveal its real origin.

Other than that, Joseph Calderón did sign most of his collaborations in the Memorial Literario, either as J.M.C.B or as "Don Joseph Maria Calderon de la Barca. ${ }^{\prime 10}$ Besides, this journal did not

\footnotetext{
8 "En las Cartas sobre los Ingleses [Voltaire] había llamado á Shakespeare 'genio lleno de fuerza, de fecundidad y de sublimidad, aunque sin el menor conocimiento de las reglas', y á la tragedia del Moro de Venecia, 'pieza muy patética'”' (1886:III.1.61).

${ }^{9}$ This can be seen by comparing his citations with the French original, which is quoted above in parallel with Calderón's text.

${ }^{10}$ See, for example, the December 1796 issue of the periodical, "Carta del célebre físico Deslandes sobre la pesca de los salmones [...]," por J.M.C.B.; "J.M.C.B.: Traductor al castellano de "Reflexiones filosóficas sobre el origen de las lenguas [...]." Or, in the table of contents: "Discurso histórico sobre el origen y progreso de la ciencia Musica," by Don Joseph Maria Calderon de la Barca (137-171).
} 
always omit the name of the authors. ${ }^{11}$ It would seem, therefore, that if Joseph Calderón published the "Reflexiones" anonymously when otherwise he usually signed his work, it was because he wanted to avoid the accusation of wrongfully using an essay by none other than Voltaire, and this would also explain why he manipulated the original so that the resulting Spanish text would be less noticeable or suspect. But I think there is a yet more decisive reason involved.

In the 18th century both governmental and ecclesiastical censorship controlled publication in Spain. The latter (i.e. the Inquisition) was the more active. Voltaire, branded the most impious of all French philosophers, was one of its most distinguished victims. His Lettres philosophiques was banned in 1756, and in 1762 all his works were outlawed (Lafarga 1975:5). There were occasional cases of leniency, but they were exceptions that confirmed the rule, and by the end of the century the situation had not changed. In the circumstances, it is understandable that the publication in Spanish of an essay by Voltaire, even if it was not "impious" and was then over sixty years old, would be considered a dangerous initiative, and that, if published, anonymity and textual manipulation would be called for. If we accept this, it would seem that, since Joseph Calderón did not claim personal authorship, the purpose of publication was to spread Voltaire's ideas without risking censorship.

5 There can be no doubt that translations of foreign critical texts on Shakespeare are also an important part of his reception. Alfonso Par, for one, discusses the Spanish rendering (1798-99) of Hugh Blair's Lectures on Rhetoric and Belles Lettres as making accessible to the Spanish readership a number of important observations on Shakespeare which otherwise would have remained unknown to them (1935:I.123-126). Likewise, the translations dealt with in the present article were useful in providing information and ideas on Shakespeare, and in contributing to the debate about him, not so much with Bergnes in 1840 , when Shakespeare was already viewed favourably in Spain, but in the two previous cases, when the issue was still open to debate. As the purpose of this article was not

\footnotetext{
${ }^{11}$ For instance, in the table of contents of the 1806 issue, we can read: "Artículo escrito en alemán por el Doctor Collenbuch" or "Extracto de una memoria leída [...] por los Sres. Fourcroy y Vauquelin" (433).
} 


\section{A. L. Pujante}

to discuss these instances as judicial cases, the focus has not been on condemning them as plagiarism or wrongful use of their originals. Instead, the aim here is to correct erroneous information and thus contribute to our knowledge of the Spanish reception of Shakespeare, while agreeing with Par on its importance.

Having said this, I hope I may be allowed to speculate about a historical aspect involved in the publication of the first two translations. Both were published as contemporary articles, but Joseph Calderón's original had appeared over sixty years before, and Romo's nearly fifty. The two renderings came out around the turn of the century, when Neoclassicism was still alive in Spain and most Spanish writings on Shakespeare were still unfavourable to him. But in France Shakespeare was being received at this time more openly than before, and Voltaire-like attitudes to him would soon be a thing of the past. In the case of Calderón, if his aim was to spread Voltaire's ideas -though censorship made it impossible to publish a Voltairean original in 1797- it would have been more to the point to bring out his unsigned text as the translation of an anonymous French original of 1734. As for the Romo appropriation of 1806, whose publication as a Spanish original provoked an angry response in a Spanish reader of neoclassical sympathies, he might have defended Shakespeare better if, instead of proposing the parallel as his own, he had presented it as the rendering of a French original of almost half a century earlier, in which France's national playwright was not even then preferred to Shakespeare; at least, his reader's reaction would have been more pondered -or there would have been no reaction at all.

\section{References}

Anon. 1760. "Parallèle Entre Shakespear \& Corneille traduit de 1'Anglois." Journal Encyclopédique Octobre: 100-105.

Anon. 1797 (marzo). "Reflexiones sobre el teatro Ingles." Memorial Literario: 352-360.

Anon. 1839. "Shakspeare." El Museo de Familias II: 381-389.

C[alderón], J.S. 1806 (30 Marzo). "Reflexîones acerca del paralelo entre Shakespeare y Corneille, inserto en el Núm. $5^{\circ}$ de este Periódico." Memorial Literario: 385-394.

Calvo, Clara 2002. "Románticos españoles y tragedia inglesa: El fracaso del Macbeth de José García de Villalta." Eds. F. Lafarga, C. Palacios \& A. 
Saura. Neoclásicos y Románticos ante la Traducción. Murcia: Universidad de Murcia: 59-72.

Calvo, Clara 2006. "De-foreignising Shakespeare: Othello in Romantic Spain." Ed. J.M. González. Spanish Studies in Shakespeare and his Contemporaries. Newark: University of Delaware Press: 117-119.

Calvo, Clara 2008. "Shakespeare, Napoleon and Juan de Grimaldi: Cultural Politics and French Troops in Spain." Eds. D. Delabastita, J. De Vos and P. Franssen. Shakespeare and European Politics. Newark: University of Delaware Press: 109-123.

Celenio, Inarco [Fernández de Moratín, L.] 1798. Hamlet. Tragedia de Guillermo Shakespeare. Madrid: Villalpando.

Deacon, Philip 1996. "La traducción de Hamlet de Leandro Fernández de Moratín." Eds. A.L. Pujante \& K. Gregor. Teatro clásico en traducción: Texto, representación, recepción. Murcia: Universidad de Murcia: 299-308.

Fernández de Moratín, Leandro 1867-1868. Obras póstumas de D. Leandro Fernández de Moratín. Madrid: Rivadeneyra.

Gregor, Keith 2002. "From Tragedy to Sainete: Othello on the Early Nineteenth-Century Spanish Stage." Eds. J.M. González and H. Klein. Shakespeare and Spain. Lewiston: The Edwin Mellen Press: 322-341.

Gregor, Keith 2003. "Shakespeare as a Character on the Spanish Stage: A Metaphysics of Bardic Presence." Eds. A.L. Pujante and T. Hoenselaars. Four Hundred Years of Shakespeare in Europe. Newark and London: Associated University Presses: 43-53.

Gregor, Keith 2010. Shakespeare in the Spanish Theatre. 1772 to the Present. London and New York: Continuum.

Juliá Martínez, Eeduardo 1918. Shakespeare en España. Traducciones, imitaciones e influencia de las obras de Shakespeare en la literatura española. Madrid: Tip. de la Revista de Archivos, Bibliotecas y Museos.

Jusserand, Jean Jules 1889. Shakespeare in France under the Ancien Régime. London: T.F. Unwin.

Kerson, Pilar R. 1989a. “Leandro Fernández de Moratín: primer traductor de Shakespeare en castellano. Antecedentes y preliminares a su versión de Hamlet." Dieciocho 12/1: 45-65.

Kerson, Pilar R. 1989b. "Moratín y Shakespeare: un ilustrado español ante el dramaturgo inglés." Ed. S. Neumeister. Actas del IX Congreso de la Asociación Internacional de Hispanistas (1986). Frankfurt a. Main: Vervuert Verlag: $75^{-83}$.

Lafarga Maduell, Francisco 1975. Voltaire en España. Difusión y traducción de sus obras hasta 1835. Barcelona: Universidad de Barcelona. 
López, Daniel 1883. "Shakespeare en España." La ilustración Española y Americana 27: no. 25, 10-11; no. 26, 22-23; no. 27, 46; no. 28, 58-59; no. 29, 74 .

López Román, Blanca 1988. "Transformaciones neoclásicas del Macbeth shakespeariano." Revista Canaria de Estudios Ingleses 17: 281-294.

López Román, Blanca 1989. "Procesos de transformación de Shakespeare en la traducción de Hamlet de Moratín." Barcelona English Language and Literature Studies 1: 117-123.

López Román, Blanca 1993. "Biografías españolas de Shakespeare." Ed. J.M. González Shakespeare en España. Crítica, traducciones y representaciones. Zaragoza: Pórtico.

Menéndez Pelayo, Marcelino 1886. Historia de las ideas estéticas en España (Tomo III, vols. I \& II). Madrid: Pérez Dubrull.

Mercier, Louis Sébastien 1773. Du théâtre, ou Nouvel essai sur l'art dramatique. Amsterdam: E. Van Harrevelt.

Moro, Pablo 1996. "Hamleto, rey de Dinamarca: un Shakespeare 'francés' a la española." Eds. A.L. Pujante \& K. Gregor. Teatro clásico en traducción: Texto, representación, recepción. Murcia: Universidad de Murcia: 331-338.

Par, Alfonso 1935. Shakespeare en la literatura española. Madrid/Barcelona: Victoriano Suárez/Biblioteca Balmes.

Pemble, John 2005. Shakespeare Goes to Paris. London and New York: Hambledon and London.

Pujante, Ángel-Luis 1999. "Spanish and European Shakespeares: Some Considerations." Folio 6: 17-38.

Pujante, Ángel-Luis ed. 2001a. El manuscrito shakespeariano de Manuel Herrera Bustamante. Santander: Sociedad Menéndez Pelayo.

Pujante, Ángel-Luis 2001b. "Shakespeare or/and..? The Spanish Counterpart in the 18th and 19th Centuries." Eds. B. Sokolova and E. Pancheva. Renaissance Refractions. Essays in Honour of Alexander Shurbanov. Sofia: St. Kliment Ohridski University Press: 157-169.

Pujante, Ángel-Luis 2005. "Limando asperezas: Juan Andrés y Shakespeare." Eds. Ricardo Escavy et al. Amica Verba. In honorem Prof. Antonio Roldán Pérez. Tomo 2. Murcia: Universidad de Murcia: 859-871.

Pujante, Ángel-Luis 2006. "Manuel Herrera on Shakespeare: A New Spanish Manuscript from the Romantic Period." Ed. J.M. González. Spanish Studies in Shakespeare and his Contemporaries. Newark: University of Delaware Press: 21-42.

Pujante, Ángel-Luis 2008. "Fame at Last: The Recent Première of Moratín's Hamlet (1798)." Eds. C. Dente and S. Soncini. Crossing Time and Space. 
Shakespeare Translations in Present-Day Europe. Pisa: Edizioni Plus. Pisa University Press: 142-152.

Pujante, Ángel-Luis \& Laura Campillo, eds. 2007. Shakespere en España. Textos 1764-1916. Granada \& Murcia: Universidad de Granada \& Universidad de Murcia.

Pujante, Ángel-Luis and Keith Gregor 2005. "The Four Neoclassical Spanish Hamlets: Assimilation and Revision." Sederi 15: 129-141.

Pujante, Ángel-Luis and Keith Gregor 2008. "Conservatism and Liberalism in the Four Spanish Renderings of Ducis's Hamlet." Eds. D. Delabastita, J. De Vos and P. Franssen. Shakespeare and European Politics. Newark: University of Delaware Press: 304-317.

Romo, G. 1806. "Paralelo entre Shakespeare y Corneille." Memorial Literario 20 Febrero: 221-228.

Ruppert y Ujaravi, Ricardo 1920. Shakespeare en España. Traducciones, imitaciones e influencia de las obras de Shakespeare en la literatura española. Madrid: Tipografía de la Revista de Archivos, Bibliotecas y Museos.

Sáiz, Ma Dolores 1983. Historia del periodismo en España. 1: Los orígenes. El siglo XVIII. Madrid: Alianza.

Urzainqui, Inmaculada 1990. "Los redactores del Memorial Literario (17841808)." Estudios de Historia Social 1-2: 501-516.

Verdaguer, Isabel 2004. "Shakespeare's 'Poem Unlimited' in EighteenthCentury Spain." Eds. R. C. Homem and T. Hoenselaars. Translating Shakespeare for the Twenty-First Century. Amsterdam \& New York: Rodopi: 129-143.

Villemain, Abel François 1838. Essai biographique et littéraire sur Shakspeare. Paris: Belin-Mandar.

Voltaire 1964 (1734). Lettres philosophiques ou Lettres anglaises. Paris: Garnier.

How to cite this article:

Pujante, Ángel-Luis. "The French Influence on Early Shakespeare Reception in

Spain: Three Cases of Unacknowledged Sources." SEDERI 20 (2010): 103-119.

Author's contact: apujante@um.es

Submission: 30/10/2009

Acceptance: 26/12/2009 


\title{
Ludwig Tieck's Herr Von Fuchs (1793) As the Perfect Embodiment of Romantic Irony*
}

\author{
Purificación Ribes Traver \\ Universitat de València
}

\begin{abstract}
This paper deals with a long forgotten German version of Volpone: Herr von Fuchs, written by the pre-Romantic playwright Ludwig Tieck in 1793 and unjustly neglected by editors, critics and theatrical directors alike. As an analysis of the play reveals, Herr von Fuchs is an accomplished and thought-provoking appropriation of a classical piece of drama which privileges the employment of Romantic irony as the best means to question widespread assumptions about political, educational, religious and aesthetic issues. It is the aim of this paper to grant Tieck's masterful example of creative translation the high recognition it deserves as a most accomplished German adaptation of Ben Jonson's Volpone.
\end{abstract}

KEYWORDS: Volpone, Tieck, Herr Von Fuchs, Romantic irony.

\section{Introduction}

Although Ludwig Tieck was the first German translator of Ben Jonson's Volpone, his most accomplished version has suffered from long, undeserved oblivion. Two factors, in my opinion, are responsible for this situation: the version's strong metatheatrical character and the success of Stefan Zweig's 1926 version of Volpone.

Considering the horizon of expectations of Tieck's audience, ${ }^{1}$ the cold reaction which his adaptation prompted from his

\footnotetext{
" Research for this essay was funded by Project FFI2008-02640-E/FILO.

' Jauss's "Erwartungshorizont" as defined in Literaturgeschichte als Provokation der Literaturwissenschaft (1970).
} 
contemporaries comes as no surprise, since, in 1793, they were unaccustomed to updates of classical texts as striking as Tieck's. Then, in the 1920s, when audiences became more receptive to Tieck's distancing techniques -as the success of his previously neglected Der gestiefelte Kater evidences- a new version of Volpone caught the public eye and became such an instant success that it rendered an unearthing of Tieck's own adaptation unnecessary.

In 1926 no one would have thought of a more suitable version of Ben Jonson's Volpone than Stefan Zweig's. His lieblose Komödie was performed in Austria, Germany and Switzerland and was soon adapted to the French stage by Jules Romains, who improved on Zweig's text and provided the Atelier with a promptbook which made Volpone famous in France and elsewhere. ${ }^{2}$

Under these circumstances no need was felt for a recovery of Tieck's eighteenth-century version of the play, even though it surpasses Zweig's adaptation in structural coherence, character development and subtlety of tone. Unlike in Zweig's version, the denouement of Tieck's adaptation does not come as a surprise; the characters do not experience sudden transformations and there is no sharp contrast between a prevailing oppressive atmosphere and a sunny happy ending with no place for poetic justice. Tieck's happy ending is in line with his tolerant approach to the characters' behaviour, in spite of each character receiving what he or she deserves. His version, moreover, retains Jonson's sharp criticism of avarice even though the punishment which his characters receive is in line with the play's amiable tone.

\section{Tieck's Free Version of Volpone}

Although Ludwig Tieck was but a university student at the time he completed his version of Jonson's satiric comedy, it is difficult to think of a text that could better meet the requirements of an ideal adaptation of a classical play. Tieck's was never a servile type of rendering but a wholly creative one which made the best possible

\footnotetext{
${ }^{2}$ For further information on the reception of Zweig's and Romains' versions see Ribes $(2007,2009)$.
} 
use of the excellent hypotext ${ }^{3}$ which Jonson had written almost two hundred years earlier. His Herr von Fuchs ${ }^{4}$ succeeded in bringing Jonson's text back to life by means of a thorough process of updating which resulted in an excellent text, from both a structural and a stylistic point of view.

That is why reading Tieck's version today becomes such a rewarding experience, for not only is its language elegant and clear, but it makes the best possible use of a structural element which most adaptors have tended to reduce or suppress: the play's secondary plot. As a matter of fact, Tieck succeeds in transforming that part which has often been omitted for the sake of clarity into a masterly exercise in Romantic irony which subtly echoes the key issues of the main plot. ${ }^{5}$

Irony, moreover, becomes in Tieck's hands a useful device to draw a critical reaction from the audience he addresses ${ }^{6}$ and, at the same time, helps him reach that desirable distance from his personal

\footnotetext{
${ }^{3}$ We follow Genette's well-known definition of the term hypotext in relation to his fourth type of transtextuality, which he calls hypertextuality (1982:11-12). To avoid confusion, he makes clear that his employment of the term hypotext differs from the meaning attached to it by Mieke Bal (1981). Genette says, "by hypertextuality I mean any relationship uniting a text B (which I shall call the hypertext) to an earlier text A (I shall, or course, call it the hypotext), upon which it is grafted in a manner that is not that of a commentary [...] It may yet be of a kind such that text $B[\ldots]$ is unable to exist, as such, without $\mathrm{A}$, from which it originates through a process I shall [...] call transformation" (1997:5).

${ }^{4}$ It was first published as Ein Schurke über den andern oder die Fuchsprelle. Ein Lustspiel in drey Aufzügen (1798) and later under the title Herr von Fuchs. Ein Lustspiel in drei Aufzügen nach dem Volpone des Ben Jonson (1829).

${ }^{5}$ In Szondi's view (1986:57-75), Tieck's comedies fulfil Schlegel's concept of irony because they disrupt the spectator's narrative illusion by having his actors (and, at times, his playwright too) step out of their usual roles.

${ }^{6}$ Christopher Norris (2009) aptly summarizes these features, which are essential to Romantic irony: "It is an attitude or ethos that calls everything into doubt, from utterer's intentions to our knowledge of the world as given (supposedly) through sensory acquaintance or the concepts and categories of reason. Such 'infinitized' irony -as distinct from its 'stable' or unproblematic varieties- aroused great interest among poet-philosophers in the early-to-mid-nineteenth century."
} 
viewpoint which, in Schlegel's view, was essential for a work of art to achieve universal validity. ${ }^{7}$

Tieck's interest in bringing his version close to his audience makes him place the action in 1793, that is to say, exactly at the time he was rewriting Jonson's comedy. ${ }^{8}$ His selection of important contemporary events -such as the French Revolution- and influential living writers, such as Goethe or Schiller, ${ }^{9}$ make it impossible for his German audience to ignore the theatrical -and, therefore, artificial- nature of the play. Its thematic concerns are thereby brought so close to the audience that they cannot abstain from taking sides with what they see, especially when the classical Socratic couple of eiron and alazon ${ }^{10}$ succeeds in drawing their intelligent -and knowing- smile. ${ }^{11}$

Tieck resorts to a mild type of irony while allowing his ridiculous, self-seeking, intransigent and boisterous characters free expression of their incontinent tongues, only to have them reduced to silence by those self-contained characters whose soft but clear

\footnotetext{
${ }^{7}$ According to him, "irony is, as it were, the demonstration of infinity, of universality, of the feeling for the universe" (1958-1995:18.128), since a literary work presents a limited perspective while it opens up the possibility of other perspectives.

${ }^{8}$ Fliege (Jonson's Mosca) and Herr von Fuchs (Volpone) joke about the duration of Herr von Fuchs' illness, which may extend into the following century, since it is already 1793: "[Fliege] Gott schenke Ihnen [...] [Herr von Fuchs] Und Gesundheit, um noch lange so krank zu bleiben. [Fl.] Daß Sie auch noch im künftigen Jahrhundert. [H. F.] Wir schreiben schon 1793, es ist nicht mehr sehr lange" [[Fliege] God give you [...] [Herr von Fuchs] And health, that my present illness lasts long. [Fl.] Even into the next century. [H. F.] We won't have to wait long. It is 1793 already] (1829:14).

${ }^{9}$ It is probably no mere coincidence that Tieck selected these two poets for this version where he reflects critically on the importance of a literary education, since, as Weiss underlines in his introduction to Schiller's Aesthetic Letters "the two poets are noteworthy as successful exponents of the two great elements of humanity, the real and the ideal $[\ldots]$ both were earnest seekers after truth: it was for both the very condition of their existence" (1845:viii-ix).

${ }^{10}$ The Oxford Dictionary of Literary Terms defines eiron as "a stock character in Greek comedy, who pretends to be less intelligent than he really is, and whose modesty of speech contrasts with the boasting of the stock braggart or alazon" (http://www.oxfordreference.com).

${ }^{11}$ It is no mere coincidence that Birnam, whose ideological bent Tieck fully shares, is only five years his younger, as we find out when Murner asks him his age (1829:3738), which makes his remarks fully meaningful to his audience and prevents their uncritical identification with what they see on stage.
} 
voices give full expression to Tieck's ideals of moderation and tolerance. Louise's voice -unlike that of Jonson's Celia- subtly, but firmly, reminds her greedy guardian Rabe (Jonson's Corvino) that he has no right to impose a husband on her or to waste her fortune. In the end she is free to offer her own hand to Karl von Krähfeld (Jonson's Bonario), and the Court of Justice declares her of age to take possession of her estate. Karl is also returned the fortune which his father, Herr von Krähfeld (Corbaccio) had greedily bequeathed unto the dying Herr von Fuchs (Volpone) in the hope of inheriting his whole fortune when he passed away. The young couple is allowed to administer those goods which their parents or guardians had misused in their own interest.

Unlike in Jonson's comedy, all harshness is removed from the play's denouement, and even the meanest characters receive a type of punishment which seeks their moral improvement. No one is lashed, sent to the galleys or confined in a damp prison.

This type of stern punishment, however, finds a place although merely imaginary- in Tieck's secondary plot, since Murner der Gelehrte (Murner the Learned, i.e. Jonson's Sir Politic) is ready to make use of the gallows and destructive fire in order to impose his ideal form of government on his prospective subjects. He has carefully designed an educational programme with no place for Philosophy, History of Art or Literature since, in his view, these disciplines go against social progress. However, it is not difficult to discover that what he really aims at is personal gain, achieved through the manual work of his uneducated and uncritical subjects. ${ }^{12}$

Paradoxically enough, this boisterous and intransigent wouldbe ruler is put to silence by a single voice, that of his wife, who not only makes him return to Germany against his own will, but even makes him write what he most detests, a poem. As Birnam -Jonson's Peregrine and Murner's eiron- teasingly remarks, that is the

\footnotetext{
${ }^{12}$ Murner's self-interested educational politics is a well-established practice, as Schiller reveals in his 1oth Aesthetic Letter: "There were men even in antiquity, who esteemed polite culture by no means a benefit, and therefore were strongly inclined to forbid the introduction of the imaginative arts into their republic. [...] How should they, who know no other measure of worth than the toil of acquisition and its palpable results, be capable of estimating the calm operation of taste upon the outward and inward man, while they regard the fortuitous disadvantages of polite culture, without its essential benefits" (1845:42; my italics).
} 
punishment which the Muses have imposed on him for having sinned against them.

It may not be mere coincidence that these very Muses are the ones which Tieck was about to serve for the rest of his life, since, after completing his Herr von Fuchs, he took the decision of becoming a professional writer. ${ }^{13}$ As personal records from this period show, his views on the importance of education were contrary to those of his character Murner der Gelehrte. As his free version of Volpone eloquently -and ironically- shows, he deemed education and literature essential to replace selfish despotism with generosity and tolerance.

\section{Tieck's Rewriting of the Secondary Plot: a Masterly Exercise in Romantic Irony}

Although Tieck's free adaptation of the main plot bears his personal mark, especially in the Romantic tone of its denouement and the strengthening of its main female character, his most original and valuable contribution is undoubtedly to be found in the secondary plot where Birnam (Jonson's Peregrine) assumes the Socratic role of the eiron by showing admiration for the eccentric arguments of Murner der Gelehrte (Jonson's Sir Politic), his Socratic alazon. Tieck deliberately avoids the dogmatic exposition of his beliefs to his audience. Instead, he allows his character Murner full freedom to voice his strong convictions while Birnam ironically pretends to share them.

Any spectator aware of Tieck's profound admiration for Shakespeare would soon find a close relationship between the name

\footnotetext{
${ }^{13}$ Tieck was well aware that society as a whole did not share the writer's range of values which were often considered too idealistic. That is why he told his friend Wackenroder, who would also devote himself to the fine arts, that what he most treasured was that which the world most despised. He addressed the following to Wackenroder on 30.11.1792: "Genau genommen solltest Du Dich ganz allein mit der Musick, und ich mit der Dichtkunst beschäftigen, denn die Welt ist wirklich nicht für uns, so wie wir nicht für die Welt, wir werden dort immer (ich leider wenigstens) ihre Wichtigkeiten unwichtig finden" [You should devote yourself wholly to the cultivation of music, and I to literature, because the world is truly not for us, in the same way as we are not for it. We, or I, at least, will always deem unimportant what the world considers important] (Wackenroder 1991:2.85-86; my italics).
} 
of his eiron and the misleading wood of Birnam which, as the witches had foretold, did come to Dunsinane: ${ }^{14}$

[Macbeth] I pall in resolution, and begin

To doubt th'equivocation of the friend,

That lies like truth. 'Fear not till Birnam wood

Do come to Dunsinane' and now a wood

Comes toward Dunsinane. $(5 \cdot 5 \cdot 40-44)$

The name of the Socratic alazon: Murner, ein reisender Gelehrte (Murner, a Learned Traveller), ${ }^{15}$ is also revealing of the character's personality and preferences. Tieck replaces the quality of "would-be politician" which he found in the Jonsonian character on which he modelled his own with that of an educated man who is proud of his knowledge. Tieck finds his source of inspiration for Murner der Gelehrte's deep educational convictions in Sir Politic Would Be's strong political opinions. While Sir Politic boasts of being acquainted with high political secrets: "I know the ebbs and flows of state" (II.i.104-105), Murner is persuaded that he would be the best ruler $^{16}$ his country could ever have.

\footnotetext{
${ }^{14}$ The fact that Tieck had recently attended a performance of the play in Nurnberg may have led him to choose this name for his subtle character. The remarks which he makes to his sister about the features of the version he had just seen on stage are most revealing of what he deemed fitting for an adaptation as well as what, in his view, should be avoided. As he tells his sister in a letter written in May 1793, Stephani's version lacked that self-restraint which was Tieck's permanent aim. He said: "Liebste Schwester, Ich bin schon in Nürnberg gewesen [...] Es war gerade eine Schauspielertrupppe da und sie spielten gerade Macbeth und gerade die Umarbeitung von Stephani, der du dich rege noch erinnern wirst, wir haben sie mehrmals auf dem kleinen Theater gespielt [...] Wenn nur die Umarbeitung selber nicht gar so kläglich wäre!" [Dear sister, I've just been to Nürnberg [...] A company was playing Macbeth, Stephani's free version, the one we used to perform at that tiny theatre [...] I'm sure you still remember [...] If only Stephani's version were less sensationalist!] (Markert 2003:353-354; my italics). Stephani's spirit was, in fact, contrary to Tieck's, who tended to suppress any scene whose sensationalism or violence could interfere with the play's thematic coherence.

${ }^{15}$ Both Sir Politic and Murner spend some time in a foreign country where they write down each single detail of their uninteresting lives, no matter how trivial they may be. Sir Politic thinks these notes are valuable for his political activities, whereas Murner means to use them to complete his books of travels which, in his view, are the only literary genre which should be cultivated.

${ }^{16}$ Murner is as ready to rule a kingdom as a republic, since, as he makes clear, their
rulers share a similar cunning use of rhetoric to manipulate their subjects. He says:
"Wenn ich König, oder Protektor, oder Dämagog wäre" [were I king, lord protector or
demagogue"] (1829:81; my italics).
} 
Ironically, all of Murner's plans aim to prevent the access of his prospective subjects to civilizing culture. He wishes to avoid their contact with Philosophy, Classic and Contemporary Literature, and any type of poetical composition which may spring from the contemplation of nature. What he wishes his subjects to develop is not their rational ability to analyze life critically but their blind acceptance of a political -and economic-programme which someone has designed for the nation's economic progress and well-being. Murner, aware of the increasing demands of the Industrial Revolution, has developed a complete programme of physical education so as to prepare his subjects for the type of manual work which they are expected to do in the future. His careful design does not omit the collaboration of a religious faction which forbids all scientific research into nature because, in their view, that would mean defying God's laws. Uncritical masses could then be asked to find their contentment in austerity and not to crave after superfluous goods. ${ }^{17}$ Even though Murner completes the presentation of his programme by saying that it is in line with the principles of the Enlightenment, ${ }^{18}$ it is not difficult to realize that it serves his own covetousness, in the same way as the oily words of Volpone's "friends" were only aimed at the engrossment of their own fortunes.

Murner thinks that his programme will favour the advancement of progress in his country and is persuaded that travel books can greatly contribute to it. According to him: "Die Reiselektüre gehört zur Aufklärung, zu den Fortschritten des Jahrhunderts" (1829:44). ${ }^{19}$

\footnotetext{
${ }^{17}$ Murner's careful design for his subjects is in line with the ironic presentation of uncritical and manipulable masses which Schiller makes in his 8th Aesthetic Letter where he describes them as follows: "Contented to escape the tedious toil of reflection, they willingly submit their ideas to the guardianship of others [...]. They embrace with eager faith the forms which the state and priesthood hold in readiness for this emergency" (1845:34; my italics).

${ }^{18}$ Although Murner insists that the aim of his educational programme is to spread the principles of the Enlightenment, the steps which he takes to enforce them immediately betray his complete ignorance of that set of principles which surrounded Tieck's education and upbringing in Berlin and which he never disdained, not even when he shared the new ideas of the early Romanticism. See Scholz (1965:128-181) for further information on the principles in which Tieck was educated at the Friedrichswerder Gymnasium in Berlin where Friedrich Gedike was headmaster.

19 "Travel books are part of the Enlightenment, they belong to the century's progress."
} 
That is why he feels proud of his own achievement: "Meine Reisebeschreibung, so kurze Zeit ich auch erst hier im Lande bin, ist doch schon einige Bände stark" (1829:38). ${ }^{20}$ The testimonies from the past are the books which Murner is intent on suppressing. The first volumes which he means to remove from the library's shelves are those from the Graeco-Roman tradition: "von allen systematischen Büchern, von allen Griechischen, Lateinischen und Hebräischen, ließe ich die Bibliotheken säubern" (1829:85-86) ${ }^{21}$ He also means to eliminate these books from the school curriculum. In his educational programme teachers will not be selected according to their knowledge of the Classics, but depending on whether they can jump on one foot or not, because physical education is the only discipline which future schoolboys should be trained in:

Statt Latein und Griechisch zu lernen, muß sich die Jugend auf Springen und Laufen legen [...] Die Lehrer in den Schulen müßten nach der Höhe rangirt werden, in der sie springen könnten; statt daß oft manche von den berühmtesten unsrer jetzigen Gelehrten nicht auf einem Bein stehen können. (1829:86) ${ }^{22}$

Murner is ready to ban the development of any discipline which might interfere with his educational programme. That is why he declares that philosophers will be sent into exile because Philosophy has the dangerous effect of favouring independent thought. ${ }^{23}$ In Murner's own words,

\footnotetext{
20 "My report is already several volumes long, even though I've only been here for a short time."

21 "I would clean libraries of all systematic books, particularly those related to the Hebraic, Greek and Latin cultures." It is difficult not to recall Goethe's deep admiration for the Classics, as expressed in his journal Die Propyläen (1788-1790), where he spoke of the superiority of the ancients to the moderns.

22 "Young people should not be taught Latin and Greek, but jumping and running. School teachers should be valued according to their ability to jump high. It is regrettable that some of our best known scholars today cannot even stand on one foot."

${ }^{23}$ Murner's views on the dangerous nature of Philosophy ironically contrast with Schiller's emphasis on its civilizing role. He highlights his viewpoint by means of the following rhetorical questions: "Shall philosophy retire then from this sphere, dejected and despairing? [...] Will the conflict of blind forces endure forever in the political world, and hostile selfishness never succumb to social law?" and stresses its positive achievement as follows: "the spirit of free enquiry has destroyed the false conceptions, which long obstructed the passage to truth, and has undermined the foundation on which fanaticism and fraud had reared their throne" (Schiller 1845:32-33).
} 
Wer in meinem Lande philosophiren wollte, der würde über die Gränze gebracht [...] Ich es verbieten ließe, daß irgend jemand philosophirte [...] das führt geradehin zum Ruin des menschlichen Verstandes [...] Die Philosophie geht recht darauf aus, die eigne freie Meinung aufzuheben. $(1829: 83)^{24}$

He speaks of a new and genuine type of Philosophy which, according to him, consists of leaving man's natural ability to reason untouched. ${ }^{25}$

He is determined not to allow any process of reasoning to interfere with what he deems man's most precious treasure: his ability to experience sensations. That is why he thinks strong feelings to be the essential quality of scientific research: "Ein starkes Gefühl in einer Wissenschaft ist mehr Werth, als hundert auseinandergesetzte Gedanken" that is to say, "ohne sich über irgend etwas in tiefsinnige Spekulationen einzulassen" (1829:82$83){ }^{26}$

According to him, man should not attempt to look into the essence of things but merely perceive their outward appearance: "Man sehe die Bäume und Berge an, wie sie sind, und nicht, wie sie sein könnten" (1829:86) $)^{27}$ because that would be an act of defiance

\footnotetext{
24 "Whoever wished to philosophize in my land, him would I have banished [...] Philosophy would be forbidden because it ruins human reason [...] and favours independent thought." Schlegel's viewpoint on the disruptive character of Philosophy matches Tieck's ironical presentation of its revolutionary nature. Schlegel (1797:42) combined Fichte's concept of "freies Selbstdenken" [freedom to think for oneself] with the idea of political freedom which could be fostered by Philosophy, "the actual homeland of irony."

${ }^{25}$ As he puts it, "Der grade Menschenverstand, den jeder mit auf die Welt bringt, das ist die wahre Philosophie" (1829:83).

26 "In scientific research, strong feelings should be preferred to a hundred thoughts [...] without allowing profound speculation to interfere with it." Tieck's irony here becomes even more apparent if we recall Schiller's opinion on the need to overcome natural laziness with education: "Energy of spirit is requisite to overcome the obstructions which faint-heartedness as well as the indolence of nature oppose to education. The goddess of wisdom [...] at her very birth [...] was to maintain a hard contest with the senses, who will not be torn from their sweet repose" (1845:33; my italics).
}

27 "Man should contemplate mountains and trees as they are, not wonder what they could have looked like." 
against his Creator: "Der Mensch muß nicht klüger sein wollen, als sein Schöpfer" (1829:86). ${ }^{28}$

All these arguments reveal Murner's wish to deprive his subjects of a critical spirit which might lead them to question his form of government. That is why he forbids his subjects free access to any kind of literature which might imaginatively create a reality different from the one they know. According to him, it is often the case that writers of this pernicious type of literature have a good command of such contaminating subjects as Philosophy and Classical Literature, usually acquired at the most execrable of institutions, the University.

He has such tender care for the mental health of his subjects that literary composition would be declared unlawful in his kingdom: "Wer sich nun gar erfrechte, einen Roman oder eine Komödie zu schreiben, der würde ohne Barmherzigkeit aufgehängt" (1829:84) ${ }^{29}$ since "Schriftsteller [...] werden auf den verwünschten Universitäten gebildet, die $\mathrm{zu}$ nichts dienen, als unsre Jugend $\mathrm{zu}$ verderben" (1829:82)..$^{30}$

That same zestful ruler who is ready to have any writer of imaginative literature hanged, is determined to use the same purifying method to suppress any trace of visual forms of art, from paintings to engravings: "Alle Kupferstiche und Gemäldesammlungen ließe ich verbrennen" (1829:86)..$^{31}$

Murner thinks so highly of his methods that he believes the French Revolution should imitate them. He regrets that, although four years have already passed since its outbreak, not all the books from the French libraries have been thrown into the sea. As he tells Birnam: "Sehen Sie nur das Frankreich an [...] Vier Jahr Revolution, und noch sind die gelehrten Folianten und Quartanten, die Gedichte

\footnotetext{
28 "Man should not wish to know more than his Creator."

29 "Whoever dared write a comedy or a novel, he would be hanged."

30 "Writers [...] are instructed in those wicked universities which are good for nothing except the corruption of the youth."

${ }^{31}$ "I would throw every single engraving and painting collection to the flames."
} 
und Romane, nicht ins Meer geworfen [...] heißt das eine Revolution?" (1829:81). ${ }^{32}$

Murner seems to feel a profound aversion to any testimony of the past which might remind him of the historical importance of literary texts. That is why he takes measures not only to remove them from the libraries but also to prevent any text of this type from being stored in the libraries of his future kingdom. Aware of the importance of education for a cultural tradition to survive, he forbids the teaching of the Classics at schools and universities: "Zuerst vernichtete ich mit einem Schlage meines Zepters alle Universitäten, alle Schulen, wo man noch and die Alten dächte" (1829:82). ${ }^{33}$

Confident of his own experience as a university student, Murner says: "Ich weiß es aus eigener Erfahrung, wie wenig man dort lernt" (1829:82), ${ }^{34}$ an affirmation which leads Birnam to remark: "Ich traue Ihnen sehr viel Erfahrung zu" (1829:82). ${ }^{35}$

Murner's bottomless ignorance (which not even the university has been able to reduce) is given full expression in his detailed exposition of his ground-breaking cultural programme. When Birnam asks him about his plans for the theatre: "Mit den Theatern?" (1829:85). ${ }^{36}$ Murner proudly describes a type of spectacle which closely resembles a fighting contest. He says: "Ich machte nämlich große Übungsplätze daraus, [...] wo alle Arten von Leibesübungen, Springen, Balgen, Laufen, getrieben würden" (1829:85). ${ }^{37}$

The most valuable qualities expected from the actors of this peculiar type of spectacle are strong fists and large backs so that they may exchange blows at leisure: "Jedem, der ein paar gute Fäuste, und einen mäßigen Rücken hätte, wäre die freie Entree vergönnt"

\footnotetext{
32 "Look at France, for example [...] Four years of revolution and not all the erudite Folio and Quarto editions, the histories and novels have been thrown to the sea. Is that a true revolution?"

33 "With a blow of my sceptre I would annihilate all those schools and universities where one could still think of the Classics."

34 "My own experience has taught me how little one can learn there."

35 "I have no doubt that you're talking from experience."

36 "Have you got any plans for the theatre?"

37 "I would turn them (the playhouses) into large training places for the practice of jumping, running or boxing."
} 
(1829:85). ${ }^{38}$ Murner ends his exposition by showing complete confidence that his dream of a National Theatre will finally come true: "Dann könnte man erst von Nationaltheatern sprechen!" (1829:85; my italics). ${ }^{39}$

Tieck's ironical handling of this issue will not go unnoticed if one recalls Lessing's opinion about the obstacles which a future National Theatre had to overcome before it could be established. As he pointed out in his Hamburgische Dramaturgie, it would require a higher cultural level in its potential audience, who, so far, had proved too lazy to achieve it (qtd. Berghahn 1997:528).

Murner, however, replaces the intellectual education of potentially dissident subjects with manual training which makes them fit for the factories: "Wer mir nicht ein Handwerk gelernt hätte, er sei Graf oder Bettler, der käme als ein Landstreicher ins Arbeitshaus. Fabriken und Handwerker sollten floriren, daß es eine Freude wäre" (1829:87). $\cdot^{40}$

As we have seen, Murner wants his state to be highly competitive. That is why he provides his subjects with the tools to achieve this end: he strengthens their muscles by means of a thorough training which they start at an early age and makes sure that they engage in no intellectual activity whatsoever. At the same time, he removes all traces of a past whose literary and artistic records might attest to its intellectual life and includes a moral programme that aims at teaching his subjects austerity: "Damit sich das Volk von der Schätzung der Nebensachen entwöhnte, müßten alle Prediger beständig in rothen Röcken gehn" (1829:87). ${ }^{41}$

\footnotetext{
38 "Anyone in possession of a good pair of fists and a strong back would be allowed free entrance to the theatre." It is moving to see the pains which Murner takes to look after his subjects. He shows such concern for their physical well-being that he intends to use part of his profits in any medical treatment which the "actors" which he has incited to fight may later require: "Das (so) eingekommene Geld aber würde auf die gewandt, die bei den Spielen etwa beschädigt würden" [money thus collected would be used to assist those who had been hurt during the games] (1829:85).

39 "We could then speak of a National Theatre."

40 "Whoever had not learned a trade -be it an earl or a beggar- he would be taken for a beggar and sent to a workhouse. It would be a pleasure to see factories and workers flourish."

41 "All parsons should wear red in order to help people disparage superfluous things." He also takes all the measures necessary to prevent frivolous behaviour from
} 
Tieck culminates his ironical presentation of Murner's cultural and educational programme by having him conclude that its implementation will foster the advancement of the Enlightenment in his country: "Die Aufklärung sollte in meinem Staate Riesenschritte thun" (1829:87)..$^{42}$ It is impossible not to smile at Murner's words when recalling Kant's definition of the movement: "Was ist Aufklärung? Sapere aude! Habe Mut, dich deines eigenen Verstandes zu bedienen!" (2004:9). ${ }^{43}$

Murner's statement sounds doubly ironical when bringing to mind Beiser's convincing argument (1992:9) that "The Aufklärung was essentially practical and, broadly speaking, a political movement [whose] fundamental aim [...] was to enlighten or educate the public, to make it aware of its civic rights and duties [...] In other words, its objective was the emancipation of the public, its liberation from the shackles of tradition, superstition, and despotism."

Having listened to Murner's wholehearted admiration for the Enlightenment, Tieck's audience can only smile at Murner's radical condemnation of reason and his enthusiastic defence of sensorial perception, especially when realizing the important role that it played in the advancement of the French Revolution. Tieck, like

flourishing among his beloved subjects. He decrees "Wer sich schminkte, oder die Lippen und Augenbraunen färbte, würde gebrandmarkt" [whoever uses makeup, lipstick or eye shadow, he will be branded] (1829:88). His zeal will no doubt foster that Calvinistic spirit which encourages hard work.

42 "Enlightenment would greatly advance in my state."

43 "What is Enlightenment? Sapere aude! Have the courage to use your reason! Dare to know!" Kant, fully convinced of the usefulness of a sound knowledge of the Classics, follows Horace's advice in his Epistles (I.2.40) and renders it literally in Latin: Sapere aude! He shares his view that the highest legacy which man can receive from knowledge is his ability to reason autonomously.

Horace's reflection on the importance of study for man's moral improvement resounds in Tieck's Herr von Fuchs, particularly in Murner's grotesque rejection of education and culture. According to Horace, "Et ni/ posces ante diem librum cum lumine, si non/ intendes animum studiis et rebus honestis,/invidia vel amore vigil torquebere" [unless you ask for a book and a lamp before daybreak; unless you devote yourself to fruitful study and honest deeds, envy and ill-will will keep you awake at night] (II.35-37; my italics).

Schiller similarly shared Horace's maxim, as evidenced in his 8th Aesthetic Letter (1845:33) where he says: "An ancient sage has detected it, and it lies concealed in the significant expression, sapere aude. Dare to be wise." 
most of his young contemporaries, at first had thought that the French Revolution would bring about true spiritual freedom. This is the view which he had expressed in a letter written to Wackenroder late in 1792: “O, wenn ich izt ein Franzose wäre! Dann wollt' ich nicht hier sitzen, dann [...] Doch leider bin ich in einer Monarchie geboren, die gegen die Freiheit kämpfte, unter Menschen, die noch Barbaren genug sind, die Franzosen ganz zu verachten" (II.161; qtd. Zeydel 1935:12). ${ }^{44}$ However, the excesses of the French Revolution made him realize that no revolution could succeed in any country unless preceded by a thorough education and enlightenment of its people.

Although, as we have seen, Murner's educational programme has nothing in common with the principles of the Enlightenment, it also falls outside of the Sturm und Drang, in spite of the emphasis which this movement places on feeling. What is more, Murner even says that the search for a deeper knowledge of nature would be an act of defiance against God, but anyone acquainted with Herder's principles would be aware of the emphasis he had placed on the poet's creative transformation of nature which turned him into a second creator. As he says in his Sämtliche Werke, "Poetry is no longer an imitation of nature but an imitation of the creative, name-giving Godhead [...] the poet becomes a second creator, poietes, maker" (xii; qtd. Berghahn 2005:534; my italics).

Any perceptive reader would also discover echoes of Rousseau's philosophy in that educational programme which highlights the importance of feelings. It would not be difficult for him to establish connections between his Emile (ou De l'education) (1762), a work which Goethe termed "Naturevangelium der Erziehung" and the outbreak of the French Revolution, which was rejected not only by Goethe but also by Tieck. ${ }^{45}$

\footnotetext{
44 "Oh, if I were now a Frenchman! I would not be sitting here, [...] But unluckily I was born in a monarchy which has fought against liberty, among men who are still barbarian enough to despise the French."

${ }^{45}$ Paradoxically enough, Rousseau's Emile would be consigned to the flames both in Paris, where it was first printed, and in Amsterdam, where it appeared a little later. Its author had to flee his country to avoid arrest and his Dutch printer, Jean Néaulme, was issued with a publication ban at the end of July 1762 .
} 
Tieck's farewell to his sister in a letter addressed to her in 1793 reveals his opposition to the French Revolution. News from France under Robespierre fill Tieck with such terror that he equates the Jacobins with the legendary Turkish threat. He says: "Gott gebe uns bald Frieden im deutschen Reich $\mathrm{u}[\mathrm{nd}]$ beschütze uns und unsre heilige Religion gegen Türken und Jacobiner" (Markert 2003:355).$^{46}$

Goethe's attitude towards the French Revolution cannot be considered any more favourable than Tieck's, since he does not even accept it as a means to achieve a National Literature. As he says in Literarischer Sansculottismus, "Wir wollen die Umwälzungen nicht wünschen, die in Deutschland klassische Werke vorbereiten könnten." ${ }^{47}$

Goethe, like Tieck, is more favourable to that spiritual type of revolution which -as he explains in the Propylaea- only true art can bring about: "Although the artist remains bound to nature and reality, the work of art, as product of the human spirit, goes beyond nature $[\ldots]$ true art transcends nature, lending it depth and significance" (qtd. Berghahn 2005:537).

Goethe's belief in the capacity of true art to transcend the limits of nature is also shared by Schiller, who showed his confidence in its capacity to illuminate the path to a better and more humane future..$^{8}$

The decision which Tieck took up around this time to devote himself wholly to the composition of literary works is the greatest proof that he completely shared Goethe's and Schiller's optimistic view of the transforming power of literature.

Like Schiller, Tieck was persuaded that literary works of a universal validity could only be achieved if the author distanced himself from his work of art. As Schiller put it, "the quality of poetry depends on the poet's artistic ability to distance himself from his

\footnotetext{
$4^{6}$ "God bless our German kingdom with peace and protect us and our holy religion against the Turks and the Jacobins."

47 "We do not want for Germany those political upheavals which might prepare the way for Classical works."

${ }^{48}$ As he puts it in his 9 th Aesthetic Letter, "Al political improvement should result from nobility of character [...] We must then find an instrument for this design [...] This instrument is the fine arts" (1845:35; my italics).
} 
personal experiences and to transform his subjective emotions into universal human feelings" (qtd. Berghahn 2005:544; my italics).

And, like some of his contemporaries, Tieck realized that irony was the best means to achieve this end, since, in Solger's view, irony was a transcendental means of contemplative enthusiasm, a union of impulse and rational lucidity (Wimsatt 1957:380). Irony, in Tieck's own words, "[Es] ist das Göttlich-Menschliche in der Poesie [...] Sie ist die Kraft, die dem Dichter die Herrschaft über den Stoff erhält" (Köpke 1855:II.238-239; my italics). ${ }^{49}$

This aspiration of harmonizing imagination and reality, ${ }^{50}$ which, as one of Tieck's biographers notes, marked his whole literary life, ${ }^{51}$ can be best symbolized in the painting of the Madonna whose contemplation filled him with enthusiasm when he saw it in 1793 (Littlejohns 1985). The painting was attributed to Raphael and Tieck went to Pommersfeld to see it. His detailed exposition of its aesthetic qualities fully reflects his own ideal. As he tells his sister Sophie in a letter:

Ich habe mich dort außerordentlich gefreut, ich habe [auch] ein Original von Raphael gesehen, es war göttlich, so ein schönes Ideal und doch so individuell [so einzig, so charakteristisch alle Züge], die höchste Ruhe der reinste Schönheit und doch Sprache und Geist in jeder Muskel der Madonna u[nd] ihres lieben Kindes. (Markert 2003:354; my italics) ${ }^{52}$

\footnotetext{
49 “[Irony] brings together the divine and the human in a poem [...] It gives poets whole control over their matter."

${ }^{50}$ This elusive synthesis of imagination and reality, moreover, is one of the defining marks of the early Romanticism and is inherent in the concept of "Romantic irony," which entails an imaginative perception of reality, since the reality which can be perceived through the senses is nothing but appearance. The true reality lies hidden behind it and can only be intuitively grasped with the help of fantasy. Schiller's advice

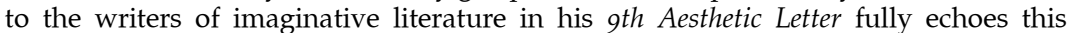
principle: "Invest them [your contemporaries] with the symbols of all that is excellent till reality bends to the ideal, and nature to art" (1845:40; my italics). For further details on the centrality of fantasy see Silvio Vietta (1983:208-221).

${ }^{11}$ In Paulin's words, “oft scheint es, als habe Tieck bewußt eine Kongruenz von Imagination und Realität angestrebt" [it often seems that Tieck is trying to harmonize imagination and reality] (1987:17; my italics).

52 "I have seen a painting by Raphael. It was so beautifully ideal and, at the same time, so real; there was harmony in its purest beauty and also life and energy in every muscle of the Madonna and her child."
} 
The clearest proof of Tieck's identification with this ideal which brings together the human and the divine is the fact that he signs the letter he addresses to his sister as "Tieck, vulgo. Raph[a]el." One could not think of a better way of showing his deep admiration for this artistic creator who embodied his aesthetic ideal.

Tieck's admiration for the Madonna was so strong that he paid two more visits to the art gallery in Pommersfeld that same year. His interest in the visual arts made him also attend Johan Dominik Fiorillo's lectures on History of Art at the University of Göttingen. ${ }^{53}$ This evidence of his love for the fine arts makes Murner's plans for his future realm doubly ironical, since, as he tells Birnam, he has the intention of burning all the collections of paintings and engravings which he might find in his hypothetical realm or republic.

Murner's plans concerning engravings sharply contrast with Tieck's great fondness for this form of art. It is most significant that in August 1794 he asked his brother "der Künstler" to engrave a design of Shakespeare for him. These are the words he wrote to Sophie: "Frage doch den Künstler einmal, ob er nicht nach einem Kupferstich eine gute Büste machen könne, wenn das geht, so soll er mir in Berlin den Shakespeare abgiessen. Ich wünsche, daß es möglich wäre" (Markert 2003:355). ${ }^{54}$

It is no mere coincidence that he wished to have an engraving of Shakespeare, as he had devoted three university terms to an intensive study of his work (Gillies 1936:206-207). Jeremias David Reuss (1750-1837), professor of Literature and librarian at the University of Göttingen, had supervised his study and had allowed him to borrow some of the valuable manuscripts which the university library kept. ${ }^{55}$

It was from this same -and well-known- library that he also borrowed Peter Whalley's 1761 seven-volume edition of Ben

\footnotetext{
53 He was the author of the famous Geschichte der zeichenden Künste von ihrer Wiederaufhebung bis auf die neuesten Zeiten (1798) (Markert 2003:337-338).

54 "Please ask the artist if he could copy a good bust from an engraved plate and, if so, ask him to carve a Shakespeare for me in Berlin. I wish it were possible."

55 As Tieck says in one of his lettters: "Ich habe ein paar alte Manuscripte von der hiesigen Bibliothek auf mein Zimmer, die ich etwas studiere" (Brief 1, Markert 2003:355) [I am now studying a couple of manuscripts from the library, which I have got in my bedroom].
} 
Jonson's Works. He studied it thoroughly and, with Eschenburg's help, was able to acquire the costly 1692 Folio edition of the Works, as he states at the back of its third blank page: "Diese Ausgabe des B.J. besitze ich schon seit dem Herbst 1793; Eschenburg hatte sie mir mit andern Engl. Büchern von London kommen lassen" (Fischer 1926a:103). ${ }^{56}$

One can easily imagine his impatience during the time he had to wait for this precious consignment. He must have feared that an untimely shipwreck might put an end to his dreams. Fortunately, the excesses of the French Revolution did not succeed in throwing his Folio and Quarto editions into the sea -as Murner would have wished for those in his realm- but he had the opportunity of studying them in such detail that, in Fischer's words, he became "einer der besten Ben Jonson-Interpreten seiner Zeit und jedenfalls der beste Ben Jonson Kenner in damaligen Deutschland" (1926a:131; my italics). ${ }^{57}$

Tieck's high level of exigency was not limited to the rigorous analysis of his sources but was also a working principle of his magnificent adaptations, whose aim was to give new life to the testimonies of the past. Romantic irony came to his help as the most effective device to keep the interest and critical awareness of his audience alive. This feature, together with the play's benign humour, spotless structure and perfect command of the language, make this version a delicate and rare dish for the most demanding palates.

\section{References}

Bal, Mieke 1981. "Notes on Narrative Embedding." Poetics Today 2/2: 41-59.

Baldick, Chris 2009. The Oxford Dictionary of Literary Terms. Oxford Reference Online. Oxford University Press.

<http:/ / www.oxfordreference.com >

\footnotetext{
56 "I own this edition of Ben Jonson since the autumn of 1793. Eschenburg had it brought to me from London, together with some other books." Tieck's high esteem for books can be evidenced in the splendid library which he left at his death. See Zeydel (1927:21-25).

57 "One of the best German critics of Ben Jonson at the time; the scholar with the deepest knowledge of his work."
} 
Beiser, Frederick C. 1992. Enlightenment, Revolution, and Romanticism. The Genesis of Modern German Political Thought 1790-1800. Cambridge, Massachussets: Harvard University Press.

Berghahn, Klaus L. 2005 (1997). "German literary theory from Gottsched to Goethe." Ed. H. B. Nisbet and Claude Rawson. The Cambridge History of Literary Criticism. Vol.4: The Eighteenth Century. Cambridge: Cambridge University Press: 522-545.

Fischer, Walther 1926a. "Zu Ludwig Tiecks elisabethanischen Studien: Tieck als Ben Jonson Philologe." Jahrbuch der deutschen Shakespeare Gesellschaft 62: $98-132$.

Fischer, Walther 1926b. "Ludwig Tiecks Shakespeare." Die neueren Sprachen 34: 102-108.

Genette, Gérard 1982. Palimpsestes. La littérature au second degré. Paris: Éditions du Seuil.

Genette, Gérard 1997. Palimpsests. Literature in the Second Degree. Trans. Channa Newman \& Claude Dobinsky. Lindoln \& London: University of Nebraska Press.

Gillies, Alexander 1936-1937. "Ludwig Tieck's English Studies at the University of Göttingen, 1792-1794." Journal of English and German Philology 36: 206-207.

Goethe, Johann Wolfgang v. 1795. Litterarischer Sanscülottismus $<$ www.Wissen-im-Netz.info $>$.

Goethe, Johann Wolfgang v. 1910 (1788-1790). Propyläen Ausgabe von Goethes sämtlichen Werken. Vol. 6. Munich: Georg Müller.

Herder, Johann Gottfried von 1994-1995 (1877-1913). Sämtliche Werke. Ed. Bernhard Ludwig Suphan. 33 Vols. Hildesheim: Georg Olms.

Herford, C.H. and Percy and Evelyn Simpson 1925-1952. Ben Jonson IX. Oxford: Clarendon Press.

Horati Flacci, Q. 1995. Opera. Ed. Shackleton Bailey. Leipzig: B.C. Teubner.

Horati Flacci, Q. 2001. The Epistles of Horace. Trans. David Ferry. N. York: Farrar Straus Giroux.

Jauss, Hans Robert 1970. Literaturgeschichte als Provokation der Literaturwissenschaft. Frankfurt: Suhrkamp.

Kant, Immanuel 2004 (1784). "Beantwortung der Frage: Was ist Aufklärung?" Ed. Erhard Bahr. Was ist Aufklärung. Stuttgart: Philipp Reclam: 9-17. [originally published in Berlinische Monatschrift (1784) 4: 481-494]

Köpke, Rudolf, ed. 1855. Ludwig Tieck: Erinnerungen aus dem Leben des Dichters nach dessen mündlichen und schriftlichen Mittheilungen. Leipzig: Brockhaus. 
Lessing, Gotthold Ephraim 1998 (1767). Hamburgische Dramaturgie. Stuttgart: Reclam.

Littlejohns, Richard 1985. "Die Madonna von Pommersfelden. Geschichte einer romantischen Begeisterung." Aurora 45: 163-188.

Lüdeke, Henry 1922. Ludwig Tieck und das alte englische Theater. Ein Beitrag zur Geschichte der Romantik. Frankfurt am Main: Diesterweg.

Markert, Heidrun 2003. “'Shakespeare, W[ackenroder] u[nd] die Natur umher machen mich sehr glücklich', zwei ungedruckte Briefe Ludwig Tiecks aus der Entstehungszeit der Romantik." Ed. Heidrun Markert. 'Lasst uns, da es uns vergönt ist, vernünftig seyn!'. Ludwig Tieck (1773-1853). Bern: Peter Lang. 331-357.

Norris, Christopher 2009. "Irony, Romantic." The Oxford Companion to Philosophy. Oxford Reference Online. Oxford University Press. <http://www.oxfordreference.com>

Paulin, Roger 1987. Ludwig Tieck. Stuttgart: J.B. Metzler.

Ribes Traver, Purificación 2007. "Stefan Zweig's Volpone, eine lieblose Komödie on Stage in Austria and Germany (1926-1927)." The Ben Jonson Journal 14/1: 61-78.

Ribes Traver, Purificación 2009. "Early Stage History of Jules Romains' Volpone." Sederi 19: 121-151.

Romains, Jules 1928. Volpone. En collaboration avec Stefan Zweig d'après Ben Jonson. Paris: Les Oeuvres Libres.

Rousseau, Jean-Jacques 1995 (1762). Emile, ou de l'éducation. Paris: Gallimard.

Schiller, Friedrich 1782. "Uber das gegenwartige deutsche Theater." WerkePhilosophische Schriften. <www.wissen-imNetz-info>

Schiller, Friederich 1845. The Aesthetic Letters and the Philosophical Letters of Schiller. Trans. \& intr. J. Weiss. Boston: Charles C. Little and James Brown.

Schlegel, Friedrich V. and J.F. Reichardt, eds. 1797. Lyceum der schönen Künste. Berlin: Johann Friedrich Unger. Vol. 1 .

Schlegel, Friedrich 1958-1995. Kritische Friedrich-Schlegel-Ausgabe. Ed. Ernst Behler. Paderborn: Schöningh.

Scholtz, Harald 1965. "Friedrich Gedike (1754-1803). Ein Wegbereiter der preußischen Reform des Bildungswesens." Jahrbuch für die Geschichte Mittel- und Ostdeutschlands 13-14: 128-181.

Shakespeare, William 1997. Macbeth. London: Norton.

Szondi, Peter 1986. "Friedrich Schlegel and Romantic Irony, with Some Remarks on Tieck's Comedies." Trans. Harvey Mendelsohn. On Textual Understanding and Other Essays. Manchester: Manchester University 
Press. 57-75. ["Friedrich Schlegel und die romantische Ironie: Mit einer Beilage über Tiecks Komödie." Euphorion 48 (1954): 397-411]

Tieck, Ludwig 1798 (1793). Ein Schurke über den andern oder die Fuchsprelle. Ein Lustspiel in drey Aufzügen. Berlin: Langhoff.

Tieck, Ludwig 1829. Herr von Fuchs. Ein Lustspiel in drei Aufzügen nach dem Volpone des Ben Jonson. Schriften vol. 12. Berlin: G. Reimer.

Tieck, Ludwig 1964 (1797). Der gestiefelte Kater. Kindermärchen in Drei Akten mit Zwischenspiele, einem Prologe und Epiloge. Ed. Helmut Kreuzer. Stuttgart: Philip Reclam Jun.

Vietta, Silvio 1983. "Der Phantasiebegriff der Frühromantik und seine Voraussetzung in der Aufklärung." Ed. Silvio Vietta. Die literarische Frühromantik. Göttingen: Vandenhoeck und Ruprecht: 208-221.

Wackenroder, Wilhelm Heinrich 1991 (1792). Sämtliche Werke und Briefe. Eds. Silvio Vietta and Richard Littlejohns, 2 vols. Heidelberg: Lambert Schneider.

Wimsatt, K., Wimsatt Jr. and Cleanth Brooks 1970 (1957). Romantic Criticism. Vol. 3 of Literary Criticism. A Short History. London: Routledge and Kegan Paul.

Zeydel, Edwin H. 1927. "Ludwig Tieck's Library." Modern Language Notes 42: 21-25.

Zeydel, Edwin H. 1935. Ludwig Tieck, the German Romanticist. A Critical Study. Princeton: Princeton University Press.

Zweig, Stefan 1926. Ben Jonsons Volpone: eine lieblose Komödie in drei Akten. Postdam: Kiepenheuer Verlag.

How to cite this article:

Ribes Traver, Purificación. "Ludwig Tieck's Herr Von Fuchs (1793) As the Perfect

Embodiment of Romantic Irony." SEDERI 20 (2010): 121-142.

Author's contact: Purificacion.Ribes@uv.es

Submission: 07/07/2009

Acceptance: 03/12/2010 


\title{
"The king has killed his heart": The Death of Falstaff in Henry $V$
}

\author{
R. Scott Fraser \\ University of the West of England
}

\begin{abstract}
Even with the multitude of religious, political, social and gendered readings of the character, critics have invariably (and understandably) tended to focus most often on the events leading up to and including the rejection scene in 2 Henry $I V$, and have given far less attention to the report of his death in Henry $V$. In light of criticism concerning the relationship between Falstaff and the actor Will Kemp, as well as the roles of the stage Vice and clown, this essay will focus on the report in an attempt to reinterpret it and its importance for the play as a whole. As will be seen, in performance it actually formed an integral part of an iterative process that would have served to problematize the presentation of kingship in Henry $V$ on the early modern stage.

KEY WORDS: Shakespeare, Falstaff, Henry $V$, Will Kemp.
\end{abstract}

Criticism concerning Falstaff is most often focused on his relationship with Prince Hal; and while the interpretation of that relationship can vary widely, it is as often dependent on the variety of symbolic attributions to Falstaff as it is to the critical approach taken by the author. Even with the multitude of religious, political, social and gendered readings of the character, critics have invariably (and understandably) tended to focus most often on the events leading up to and including the rejection scene in 2 Henry IV. However, this essay will focus on references to the heart in both 1 and 2 Henry $I V$ and Henry $V$ as a means of exploring the symbolic relationship between Falstaff and Henry in the latter play. As will be seen, in performance such references formed part of an iterative process that would have served to problematize the presentation of 
kingship of Shakespeare's Henry on the early modern stage, and nowhere is this more evident than in the report of Falstaff's death.

Central to this reading is the established criticism concerning Falstaff and the actor Will Kemp, as well as the roles of the stage Vice and clown. It is, of course, Hamlet who famously complains about but also defines the comic role of the early modern stage clown:

And let those that play your clowns speak no more than is set down for them, for there be of them that will themselves laugh to set on some quantity of barren spectators to laugh too, though in the mean time some necessary question of the play be then to be considered. That's villainous, and shows a most pitiful ambition in the fool that uses it. $(3 \cdot 2 \cdot 34-40)^{1}$

Given his own ambitions as a playwright, Hamlet sees the clown as a threat to any planned performance: because the role was one given to improvisation and direct address, the clown subverted the authority of the written text. Even the clown's scripted lines were frequently asides of complaint or comment; and his function was as the audience's direct and frequently crude (in both senses of the word) commentator on the action.

While it was Brinsley Nicholson who first argued that Hamlet's speech was a reference to Will Kemp (1882:57-66), it was John Dover Wilson who went so far as to argue that Shakespeare created a character based directly on the comic actor's abilities (1943:47). Expanding on a suggestion by Sir Arthur Quiller-Couch (1918), that 2 Henry IV is built around the morality play structure, Wilson argues that the prince has to choose between the two characters of Falstaff (who stands for misrule) and the Lord Chief Justice (who stands for law and order) (1943:75). He also makes a significant point regarding the absence of Falstaff from Henry $V$, by arguing that the character was absent (despite the promises of the Epilogue to 2 Henry IV) because Kemp left Shakespeare's company in 1599 (1943:124-125).

However, numerous critics have since challenged this emphasis on the morality structure, as well as the paratextual reason for Falstaff's absence. For example, A. P. Rossiter first took exception to what he saw as the reductiveness of Wilson's reading, claiming that

\footnotetext{
${ }^{1}$ All references to Shakespeare's plays are from the Norton collected edition, edited by Stephen Greenblatt.
} 
"any ideological view which makes Henry IV into a princely morality tale reduces Falstaff to little more than a symbol of all the fat and idle temptations which royalty rejects" (1964:103). For Rossiter, the absence of Falstaff from Henry $V$ can therefore be explained by the need for the new king to remove the political liability of the comic criticism of his leadership (1964:111). ${ }^{2}$ Kristen Poole, while acknowledging the influence of the Vice, also sees Wilson as being too simplistic in his reading. She locates the character in the tradition of the Puritan of the staged Marprelate Tracts, and determines that when an audience saw Falstaff they also saw Oldcastle. Yet, she argues that as "a multivalent, polyvocal entity, 'Falstaff', the epitome of the carnival grotesque, encompasses and embodies contradictions, rather than flattens them" (1998:105-108). But as refined and accurate as her argument is, to tie Falstaff to a single signification paradoxically limits his possibilities as a "polyvocal entity." Arguably not the focus of her essay, she does not consider the significance of Kemp playing Falstaff in and of itself.

David Wiles convincingly argues that not only did Kemp play Falstaff, but that again the part was actually written for the actor, as Wilson first suggested. Wiles constructs this argument with four points. First, he follows Wilson's lead concerning the absence of Falstaff from Henry $V$, restating that the departure of Kemp coincides with the dating of the play. Second, he points out that Kemp was the probable pirate of the quarto text of Syr John Falstaffe, and the merrie Wives of Windsor (1602). Third, he again follows Wilson's lead, this time over the assertion that the stage direction "Enter Will" in second act of the quarto of 2 Henry IV refers to Kemp playing Falstaff. And finally, he describes how the clowning "rhythm" of Kemp's roles fits with those of Falstaff (1987:118-119). While the plausibility of Kemp's piracy is certainly questionable, overall this is an argument that has been given considerable critical acknowledgement. And central to this essay's reading of Falstaff is Wiles' assertion that, "Kemp and Falstaff are one and the same" (1987:120). This is of notable importance, particularly if one considers the possibility that when Kemp walked on stage some early modern audience members might have seen Falstaff, some might have seen Oldcastle, and some might have seen Kemp

\footnotetext{
${ }^{2}$ The first quarto does not include the same references to Falstaff, truncating the report of his death as it does with so much more of the play.
} 
himself. Indeed, as a "polyvocal entity," some might have seen a combination of all three. Such a view depends not simply on Wilson and Wiles' argument that the part was written for the actor, but that Kemp performed in the metatheatrical tradition of the early modern Vice figure.

While secularized, the Vice never fully lost its symbolic function in the early modern period. Such a view is influenced by the work of Bernard Spivack, who argues that the Vice's role, "much older than his histrionic title, came into its key position as soon as the martial allegory for the Psychomachia was transformed by the stage into a plot of intrigue" (1958:140-141). Wiles continues and expands this critical tradition, noting that "vice' is often used as a synonym for fool in the sixteenth century [...] Just as the fool in the Morris dance broke formation and danced where he pleased, so the Vice swept aside the confines of the script" (1987:4-5). In terms of the relationship between Falstaff and the prince, Wiles points out how Hal refers to him with language drawn from the morality tradition (such as 'devil', 'vice', 'iniquity', 'ruffian' and 'Satan'), and that Falstaff wields a wooden (as opposed to actual) dagger (1987:122).

The view of the role of the Vice begun by Spivack and expanded with the work of Wiles has led to a number of interesting interpretations of Kemp's influence on early modern drama, most notably in terms of the subversion of the "confines of the script." Robert Weimann notes the negative stage reference to Kemp in Everard Gulpin's Skialetheia (1598), and Kemp's appearance in The Return from Parnassus (1599/1601) to conclude that "the performed clown, good-humoredly, or so it seems, is made to attest to a distinct gap between learned pens and vulgar voices by 'disfiguring' classical authority at one of its most highly respected levels" (2000:123). ${ }^{3}$ And just as Weimann reads the roles of this particular actor as illustrating the overall struggle between actor and author in the early modern period, one can also read Kemp's role as Falstaff as illustrating through its improvisational performance a critique of both the prince of the Henry IV plays and the king in Henry $V$.

That Kemp was famous beyond his individual stage roles around the time of the first performance of Henry $V$ is evidenced by

\footnotetext{
${ }^{3}$ For an argument contrary to the interpretations of the Vice by Spivack and others (including Weimann), see Cox (2000).
} 
the popularity of his Nine Days' Wonder, the account of his London to Norwich dance published in 1600. And while it is, of course, impossible to know precisely what he did on stage, there are internal consistencies in the clown's scripted lines that shed further light on his symbolic importance. Wiles notes the fact that the clown speaks in prose when most of a play is in verse, and this creates an "illusion of spontaneity, of an actor who is speaking to the audience in propria persona" (1987:9). And on a more political level, Phyllis Rackin suggests that Falstaff's prose is so given to wordplay and improvisation that it subverts the rigidity of "official language" (1991:238). Thus, the fame of Kemp at the time, combined with the metatheatricality and onstage independence of the clown/Vice, suggests that what members of the audience might have seen was not simply a character per se, but a cameo by a well known actor given to improvisation and subversion.

There is a notable verbal repetition that runs through Kemp's Shakespearean appearances, and which supports this point. For example, building on the stage direction in Q2, "Enter Will Kemp" Wiles concludes that he played the part of Peter in Romeo and Juliet (1594-1596). These were Kemp's scripted lines:

PETER. Play 'Heart's Ease'

Musician. Why 'Heart's Ease'?

PETER. Oh musicians because my heart itself plays, my heart is full.

Oh play me some merry dump to comfort me. (4.5.100-103; my emphasis)

It was William Hazlitt who first critically applied the phrase "heart's ease" to that other Kemp character, Falstaff: "Falstaff's wit is an emanation of fine constitution; an exuberance of good-humour and good-nature; an overflowing of his love of laughter and goodfellowship; a giving vent to his heart's ease, and over-contentment with himself and others" (1889:82). Hazlitt's use of the phrase was perhaps determined by its appearance in Henry $V$. Following his argument with Williams on the eve of Agincourt, Henry has the soliloquy in which he states:

[...] What infinite heart's ease

Must kings neglect that private men enjoy!

And what have kings that privates have not too,

Save ceremony, save general ceremony?

And what art thou, thou idol ceremony? (4.1.233-237; my

emphasis) 
The suggestion from Henry is that "heart's ease" relates to the private lives that commoners enjoy and that kings must neglect in order to create the public image of kingship; or, indeed, to separate the king's two bodies.

Arguably, this is simply one of the frequent references in 1 and 2 Henry $I V$ and Henry $V$ to the burdens of kingship. Yet the repetition of the phrase "heart's ease" is particularly interesting as it only appears in Shakespeare's Romeo and Juliet, Henry V, and Julius Caesar (1599). In the latter play, an exact contemporary of Henry $V$, these lines are spoken by Caesar in his description of the politically ambitious challenger to his political power, Cassius:

Would he were fatter! But I fear him not.

Yet if my name were liable to fear,

I do not know the man I should avoid

So soon as that spare Cassius. He reads much,

He is a great observer, and he looks

Quite through the deeds of men. He loves no plays,

As thou dost, Antony; he hears no music;

Seldom he smiles, and smiles in such a sort

As if he mocked himself and scorned his spirit

That could be moved to smile at any thing.

Such men as he be never at heart's ease

Whiles they behold a greater than themselves,

And therefore are they very dangerous.

I rather tell thee what is to be feared

Than what I fear, for always I am Caesar.

Come on my right hand, for this ear is deaf,

And tell me truly what thou think'st of him (1.2.199-215; my

emphasis)

A fat man, it would seem, is not someone with obvious political ambition: Cassius's leanness suggests that he denies his "heart's ease," or private pleasure, as he wishes to overtake those with a greater public position than himself ("Would he were fatter"). At the same time, Caesar, because he is a public figure ("for always I am Caesar"), cannot express the thoughts of his private self.

This is not to state that Kemp appeared in Julius Caesar, but to note that the same symbolism can be said to be true in the Henry IV plays: Falstaff's political ambitions are not for himself, but the younger, leaner Hal. Unlike Rossiter's objection to Wilson's morality reading, which he claimed reduced Falstaff to "little more than a 
symbol of all the fat and idle temptations which royalty rejects" (1964:103), much has since been made of the symbolic nature of Falstaff's corpulence in relation to Hal's thinness, most notably in readings that focus on the carnivalesque. For François Laroque, the juxtaposition serves as "a comic counterpoint to the real battles opposing the rebels to the king. This is a popular form of psychomachia where the strings of parodic litanies belong to the genre which Bakhtin calls 'praise-abuse'" (1988:87). And Jonathan Hall argues that the symbolic corpulence and leanness can be read as follows: "The language of the 'grotesque body' in this play is made to appear as an agent of potential chaos and civil war [...] Thus the casting-off of Falstaff, which is correlative to the stern policies of the centralizing state, is also intensely desired." Yet at the same time, "When [Henry] finally replaces the monologizing mockery with an act of banishment, separating his controlling self from the grotesque old body, he is denying something in himself" (1998:126-128).

That such banishment was to be expected is, of course, foreshadowed in 1 Henry IV in the scene in which Falstaff, playing the role of the king says, "Banish plump Jack and banish all the world." Hal famously replies, "I do; I will" (2.5.438-439). When confronted by his real father, Henry IV, he promises: "I shall hereafter, my thrice gracious lord, / Be more myself" (3.2.92-93). That is, he will be more the prince and heir to the throne than the young man indulging a private existence; for like Caesar, when he becomes the ruler he will have to appear only as his public self. Further, that Henry's public success as king would require not only the banishment of Falstaff, but his death, is hinted at in the Epilogue to 2 Henry $I V$, which promises not only the return of the knight, but his death of a sweat. With the loss of Kemp, there is a sense in which Falstaff could not physically return at all; but the character could still die in Henry $V$, albeit off stage.

Significantly, the symbolism employed in the report of Falstaff's death in Henry $V$ forms part of an iterative process begun in 1 Henry $I V$. On stage, in the penultimate scene of the play, are the "bodies" of the two characters Hal must symbolically overcome before he can be king: Hotspur and Falstaff. Over the body of Hotspur, Hal says these lines: "Fare thee well great heart. / Ill-weaved ambition, how much art thou shrunk!" (5.4.86-87; my emphasis). Then, in the "rejection" scene of 2 Henry $I V$, we have the following: 
FALSTAFF My king, my Jove, I speak to thee my heart.

KING I know thee not, old man. (5.2.42-43; my emphasis)

One might be tempted to dismiss the repetition of the word "heart" as a coincidence, but arguably Hotspur's "heart" has to be killed because it is too great with ambition and cannot last; Falstaff's "heart" has to be rejected because it is given to misrule.

Of course, the rejection scene is not the end of 2 Henry IV. There is the Epilogue, obviously spoken by Kemp himself, and his final jig. As Wiles points out, "With Kemp/Falstaff's dismissal by Hal, and his reappearance in the jig, the conventional structure of comedy is restored. Clown and protagonist are relegated to their separate spheres which, in other Shakespearean comedies, are much more sharply demarcated" (1987:129). Such symbolic demarcation prepares the way for Henry $V$, where the language with which the death is reported, and the location of the report within the play, can be read as particularly significant:

HosTESs. By my troth, he'll yield the crow a pudding one of these days. The King has killed his heart. Good husband come home presently [...] As ever you come of women, come in quickly to Sir John. Ah, poor heart, he is so shaked of a burning quotidian, that it is most lamentable to behold. Sweet men, come to him.

Nim. The king hath run bad humors on the knight, that's the even of it.

PISTOL. Nim, thou hast spoke the right.

His heart is fracted and corroborate. (2.1.78 -113; my emphasis)

Given that in the psychomachia tradition of the Vice, Kemp/Falstaff has represented all that Henry must deny, the ambiguity of whose heart is "His" becomes quite palpable. It is certainly possible that the reference is to the heart of Henry as much as the knight. Gary Taylor cryptically suggests this in his notes to the lines in the Oxford edition: "His probably Falstaff's; arguably Henry's fracted and corroborate broken and healed. The apparent nonsense is easily explained by Pistol's plunge into Latinity" (1982:130; his emphasis). T. W. Craik, in the Arden edition, provides a slightly different gloss to the lines, but also sees Pistol as being inaccurate: "Fracted (Lat. fractus) does mean 'broken' [...] but corroborate (Lat. robur, 'strength') means 'strengthened', not as Pistol perhaps supposes, 'in ruins', 'reduced to rubble'" (1995:166). Yet the latin robur can also mean "hardness", "firmness", "vigor", and 
"power" (Lewis 1879:1597). By glossing the word with any of these, one can see that Pistol may actually be correct on a symbolic level: the private heart has had to be broken and killed off so that Henry's public self can be either hardened, or made more firm, vigorous and/or powerful, and he can be an effective king.

In Henry $V$, the king is referred to as the cause of Kemp/Falstaff's death ("The king hath run bad humors on the knight"); and its report has highly symbolic connotations. For David Ruiter, the sense of community and festivity that Falstaff engendered through his actions and the expectations surrounding his promotion in 2 Henry $I V$ are continued in Henry $V$, but are now based on the expectation of his death. "In addition, Falstaff's imminent demise is not attributed to his wild and gluttonous life, but to the reformed and severe King Henry" (2003:152).

Given that, with the absence of Kemp, Falstaff could not appear in Henry $V$, the death is understandably reported as early as possible (otherwise an audience would spend too much time waiting for Kemp/Falstaff to arrive). Yet this does not mean the end of references to the missing character. Shakespeare goes out of his way to remind his early modern audience that he is not in the play as late as the penultimate act, by having Fluellen and Gower discuss him directly:

GOWER Our King is not like him in that: he never killed any of his friends.

FLUELLEN It is not well done, mark you now, to take the tales out of my mouth ere it is made an end and finished. I speak but of the figures and comparisons of it. As Alexander killed his friend Clytus, being in his ales and cups, so also Harry Monmouth, being in his right wits and good judgements, turned away the fat knight with the great-belly doublet: he was full of jests and gipes, and knaveries, and mocks; I have forgot his name.

GOWER Sir John Falstaff.

FLUELLEN That is he. I tell you there is good men porn at Monmouth.

GOWER Here comes his majesty. (4·7·39-53)

As many have noted, the implication is that, like Alexander, Henry indeed is one who kills his friends. But once again the conversation provides a juxtaposition of the banished/killed private 
self ("Sir John Falstaff"), and the successful public one ("his majesty"). Interestingly, while acknowledging that this scene would therefore recall the sadness of the report of Falstaff's death, Craik also notes the inherent comedy based on the nature of Fluellen's comparison, and his need to describe the dead knight because he has forgotten Falstaff's name. Craik asks, "Did some wag in the audience hereupon cry 'Oldcastle'? The covert joke between actors and audience implies the latter's familiarity not only with the history plays themselves but with their recent theatrical history" (1995:60). Given all of the above, some "wag in the audience" might have cried "Kemp."

But it could be argued that all references to the Eastcheap characters remind the audience of Kemp/Falstaff's absence, thereby providing an implied critique of the king throughout the play. And as Gary Taylor has noted, Shakespeare "clearly makes Henry responsible for the deaths of two of them, Falstaff and Bardolph and does so as part of a dramatic sequence which shows Henry increasingly burdened and isolated" (1982:46). But there are also implied references. For example, Barbara Hodgdon has pointed out how Fluellen's beating of Pistol and forcing him to eat the leek reworks Falstaff's banishment in 2 Henry IV, and that "Pistol's last words, based in part on Dericke's return to England in The Famous Victories and on Falstaff's similarly positioned soliloquy in I Henry IV (5.4.158-161) [...] link him rather precisely with Falstaffian lies" (1991:193).

Similarly, the earlier comic scene between Williams and the king provides another possible allusion to Kemp/Falstaff. Williams, not knowing to whom he is speaking because Henry is in disguise, argues with him on the eve of Agincourt. A Shakespearean invention, and the most direct criticism of the king since the report of the death, it is also the conversation which leads to Henry's soliloquy concerning heart's ease. Later, when Williams discovers his error, he describes it as follows:

WiLLIAMS All offences, my lord, came from the heart:

Never came any from mine that might offend your majesty.

KING It was our self thou didst abuse.

WILLIAMS Your majesty came not like yourself: you appeared to me but as a common man - witness the night, your garments, your lowliness; and what your 
highness suffered under that shape, I beseech you take it for your own fault and not mine, for had you been as I took you for, I made no offence; therefore I beseech Your highness pardon me. (4.8.47-57; my emphasis)

Again there is the juxtaposition of the private self ("the heart"), and the public self ("Your majesty came not like yourself"). But as Craik has pointed out, the passage is in verse but metrically defective ("It was our self thou didst abuse"). "The phrase 'our royal self' [...] would be appropriate to the tone here, and is not disproved by Williams's reply, for 'Your majesty came not like your royal self' (quoting the phrase back in a prose sentence) would smack of insolence" (1995:327). The line could be defective because the references to the gap between the public ("majesty") and private self ("heart") actually upset the king, reminding him of the frustrations expressed in his own soliloquy. While such a point cannot be proven, Henry does indeed pardon Williams, thereby implying he accepts that the fault was his own for disguising "himself" as a common, private man. What the scene does provide is yet another instance where we are reminded of what the king has had to give up in order to achieve his political ambitions.

In light of the work of numerous critics, but particularly Wiles' conclusion that Kemp and Falstaff are one and the same, it has been possible to reinterpret such references to the heart in Henry V. As noted above, it is impossible to know precisely what Kemp/Falstaff did on stage, but the scripted lines suggest that at least one of his symbolic functions was, in the theatrical tradition of the Vice, to provide an opposite to the prince's public self, an opposite which has to be rejected in order for him to become an effective king. Because of Kemp's absence, Falstaff could not appear in Henry $V$; but he could still be referred to, either directly or indirectly. References to the heart in the play therefore form part of an iterative process that serves to continue to problematize the role of the king as Kemp/Falstaff himself had previously done on stage. Central to these references is the report of the death. For an ambitious playwright like Hamlet, such a figure must be contained; for an ambitious ruler, such a figure must be killed, leaving a king's heart both "fracted and corroborate." 


\section{References}

Cox, John D. 2000. The Devil and the Sacred in English Drama, 1350-1642. Cambridge: Cambridge University Press.

Hall, Jonathan 1998. "The Evacuations of Falstaff (The Merry Wives of Windsor)." Ed. Ronald Knowles. Shakespeare and Carnival: After Bakhtin. London: Macmillan: 123-151.

Hazlitt, William 1889. William Hazlitt Essayist and Critic. London: Frederick Warne and Co.

Hodgdon, Barbara 1991. The End Crowns All: Closure and Contradiction in Shakespeare's History. Princeton: Princeton University Press.

Howard, Jean E. 1997. "1 Henry IV." Ed. Stephen Greenblatt. The Norton Shakespeare. London: W. W. Norton and Company: 1147-1156.

Laroque, François 1998. "Shakespeare's 'Battle of Carnival and Lent'. The Falstaff Scenes Reconsidered ( 1 E 2 Henry IV)." Ed. Ronald Knowles. Shakespeare and Carnival: After Bakhtin. London: Macmillan: 83-96.

Lewis, Charlton T. and Charles Short eds. 1879. A Latin Dictionary. Oxford: At the Clarendon Press.

Nicholson, Brinsley 1882. "Kemp and the Play of Hamlet - Yorick and Tarlton - A Short Chapter in Dramatic History." The New Shakespeare Society's Transactions (1880-1882). Part 1. London: Trübner and Ludgate Hill: 57-66.

Poole, Kirsten 1998. "Facing Puritanism: Falstaff, Martin Marprelate and the Grotesque Puritan." Ed. Ronald Knowles. Shakespeare and Carnival: After Bakhtin. London: Macmillan: 97-122.

Rackin, Phyllis 1991. Stages of History: Shakespeare's English Chronicles. London: Routledge.

Rossiter, A. P. 2004 (1964). "Ambivalence: The Dialectic of The Histories." Ed. Russ McDonald. Shakespeare: An Anthology of Criticism and Theory. Oxford: Blackwell: 100-115.

Ruiter, David 2003. Shakespeare's Festive History: Feasting, Festivity, Fasting and Lent in the Second Henriad. Aldershot: Ashgate.

Shakespeare, William 1997. The Norton Shakespeare. Ed. Stephen Greenblatt. London: W. W. Norton and Company.

Shakespeare, William 1982 (1599). Henry V. Ed. Gary Taylor. The Oxford Shakespeare. Oxford: Clarendon Press.

Shakespeare, William 1995 (1599). King Henry V. Ed. T. W. Craik. The Arden Shakespeare, Third Series. London: Thomson Learning. 


$$
\text { (Q)ederi } 20 \text { (2010) }
$$

Spivack, Bernard 1984 (1958). "The Vice as a Stage Metaphor." Ed. Peter Happé. Medieval English Drama: A Casebook. Basingstoke: Macmillan: 140144 .

Weimann, Robert 2000. Author's Pen and Actor's Voice: Playing and Writing in Shakespeare's Theatre. Cambridge: Cambridge University Press.

Wiles, David 1987. Shakespeare's Clown. Cambridge: Cambridge University Press.

Wilson, John Dover 1943. The Fortunes of Falstaff. Cambridge: Cambridge University Press.

How to cite this note:

Fraser, Scott R. "“The king has killed his heart": The Death of Falstaff in Henry V." SEDERI 20 (2010): 145-157.

Author's contact: Scott.Fraser@uwe.ac.uk 


\title{
John Elliott. 2009 \\ Spain, Europe and the Wider World, 1500-180o New Haven and London: Yale University Press
}

\author{
Juan E. Tazón \\ Universidad de Oviedo
}

With his accustomed degree of honesty and responsibility, for which many have expressed gratitude over the years, J. H. Elliott offers with this book a necessary sequel to his previous volume of selected essays Spain and its World, 1500-1700 (New Haven and London, 1989). Articles and lectures dating from 1990 onwards have been collected and, in certain cases, reprinted again to show, primarily and convincingly, Spain's leading role in the history of the early modern period and its many points of affinity with other European states. This does undoubtedly give unity to the enterprise while it shows the great scholarly capacity of the author to search for connections, thus destroying the myth of exceptionalism with which, for several and dubious reasons, Spanish history of the period has been too often associated. The impressive network of connections established -diplomatic, political, commercial, personal etc- serves the central purpose of showing links between lands and peoples of early modern Europe which, in turn, were extended across the Atlantic during the age of colonial expansion.

The search for connections, however, does not result in an underestimation of differences. Spain may well have occupied an exceptional position in early modern Europe, but the danger of exaggeration for the historian is patent. Elliott occupies the middle ground, explaining difference and similarity, and subverting, when necessary, traditional approaches which new facts render dubious. Chapter I, which explores "unity" and "disunity" in a Europe structured round the axis of a number of "composite" monarchies, becomes in itself a clear example of the above-mentioned capacity for the establishment of similarities and differences by means of comparison. It also shows the need to assess history of the period 
abandoning, to a great extent, the idea of unitary nation states, which a basic comparison of numbers makes evident: the five hundred independent political units of Europe in 1500 become about twentyfive by 1900 , the Versailles settlement of 1919 signalling the triumph of the so-called "principle of nationality." The need, therefore, for a change of perspective in the historian of the period is obvious, and Elliott does it by applying "contemporary" tools, such as the writings of Juan de Solórzano, a seventeenth-century Spanish jurist, who explains the two basic different ways of "uniting" acquired territories with a king's other dominions. On the one hand there is the "accessory" union, where a province or a kingdom was regarded juridically as part and parcel of another one, with its inhabitants in possession of the same rights and subject to the same laws; and, on the other hand, the aeque principaliter type of union, where different constituent kingdoms maintained after their union the right to be treated as distinct entities. This second method, employed with considerable success by the Spanish Habsburgs in trying to hold together the Spanish Monarchy during the sixteenth century, brought about, however, a myriad of problems that need new evaluation: resentment in certain areas, from subjects who felt neglected by the prince; restraints imposed on monarchs by local institutions, which became acute when they tried to impose, for instance, a fiscal policy; disparity in customs and ways of life; the political need for integration; loyalty... Elliott enumerates and examines them all, bringing into the picture the new religious dynamics of the sixteenth century and the sense of self-worth that certain areas acquired in opposition to others with the colonial expansion of the period. In so doing, therefore, he inevitably recognises the need to explore in parallel, for instance, the gulf between England on the one hand and Scotland and Ireland on the other, this being a phenomenon which does not differ much from the position of Castille in relation to other areas of the Spanish Monarchy. Thus, "unity in disparity" became for many of the following years an acute political problem, shared by contending monarchies who inevitably examined each other in their respective searches for a solution, the one adopted by Madrid, with its victory over the rebels of Aragon, Valencia and Catalonia being in the end the most unitary.

This capacity to learn from others, even if it meant copying enemy solutions, is examined in several chapters, though the most 
detailed analysis is rendered in Chapter II, in which Elliott pays homage to the figure of Hugh Trevor-Roper, one of the first figures to explore the possibilities of comparative historical studies. Aspects, for instance, such as court etiquette during the rule of Charles I in England or political manoeuvres like the Anglo-Scottish alliance, find a well studied background in the parallel cases of the court of Philip IV or the union of Castile and Portugal. Elliott, of course, moves with incomparable confidence with this material. To readers of his masterpiece, the biography of Count-Duke of Olivares, the amount of new information supplied may perhaps appear to be scant, but, all in all, chapters like the above-mentioned offer a superb compendium of facts and well-defined fields which, in many cases, as admitted by the author, are still in need of new evaluation. One such case, for instance, is Ireland and the role it played in the early colonial efforts that England made in Virginia. Once again, the comparative case with Spain, with its very strong conquistador element, is well established. But Elliott goes a step further when he admits in the second part of his book (Chapter VIII) the need to revaluate the question of Ireland in connection with the lack of confidence that English settlers showed in America when it came to the treatment of native populations, in contrast with the inclusionist philosophy of the Spaniards. This capacity, therefore, to demonstrate new areas for research, for which many of his students have benefited over the years, appears as a very relevant fact to be taken into account. United to the very wide spectrum of fields analysed, in itself a lesson on the possibilities of research open to the new historian, it becomes a generous and inviting offer on his part for any scholar interested in the period.

To conclude, this book, divided into three sections (Europe, A Wider World, and the World of Art), will no doubt occupy a well deserved place both among the selected bibliography of the period and the works of general reference and introductions. With its double perspective, factual and methodological, it is compulsory reading.

How to cite this review:

Tazón, Juan E. Review of John Elliott, 2009. Spain, Europe and the Wider World, 1500-1800. New Haven-London: Yale University Press. SEDERI 20 (2010): 161-163. 


\title{
Jesús López-Peláez Casellas. 2009 "Honourable Murderers" El concepto del honor en Othello de Shakespeare y en los dramas de honor de Calderón Bern-Oxford: Peter Lang
}

\author{
Luciano García García \\ Universidad de Jaén
}

One of the most promising fields of research on Anglo-Spanish relationships of the Modern Period is no doubt that of contrastive relationships. Scholars working in this field endeavour to work on the un-genetic comparison of both literatures to elucidate terms of affinity and contrast. These may eventually lead to a better comprehension of the situation of both national domains, the context for genetic relationships and, above all, they can tell us a lot about the higher level of general literature, as they reveal pertinent similarities and differences. Because of this, it is most surprising that a topic like the one dealt with in the present book has received so little attention either by English or Spanish scholars of this speciality.

Admittedly, there are several relevant studies on honour in both the English and the Spanish sides. Not to tire the patient reader, or repeat what has been said before, I refer him or her to the author of this book himself in his Bibliography and in his review of Fernie's Shame in Shakespeare, where he displays his apt and broad knowledge of the state of the art. As to the matter of the Spanish side of the question, there is an abundant output which has exhaustively dissected all the aspects and minutiae of this element of mentality (or, to use the term frequently advocated in the book reviewed here, this element of the structure of feeling) of the Spanish Golden Age. Do I need to quote the studies by Menéndez Pidal, Caro Baroja, Maravall, Castro, Correa, Gutierrez Nieto, Jones, Oostendorp, Ricart, Wardropper? There is even a wider corpus on Calderón and honour, with the inaugural work of Viel-Castel (1841) and the seminal ones 
by Parker $(1962,1975)$ introducing the consideration of Calderonian drama as a Spanish form of tragedy, and the happy continuance of this line at the hands of critics such as Cruickshank, Ruiz Ramón or Antonio Regalado, to quote just three of many. Yes, there are many and good studies on the analysis of Spanish dramas of honour. What is imperatively lacking is an apt output of works which may salvage the gap between the Spanish and the English side in this topic of dramatic literature. ${ }^{1}$ If we revise the current bibliography on the subject it scarcely amounts to more than ten items, some of which are brief incidental pieces: Ruiz Silva and Alvarado (1979), Wilson (1980), Mintz (1982), Dañobeitia Fernandez (1992), Romero Cambra (2002), López-Peláez Casellas (1995, 1998, 2004a) are just some of them. And it is here where this book arrives in good time to meet an impending need. For it is the first comprehensive account to broach the many and significant relationships concerning honour in both countries, in a corpus extensive enough to derive general conclusions (Othello, A secreto agravio, secreta venganza, El medico de su honra, and El pintor de su deshonra), bridging thus a gap that has remained open for too long in Anglo-Spanish literary relationships.

The book fully accomplishes its programme, which is rooted in new historicism, cultural materialism, and cultural semiotics. As a new historicist and cultural materialist, the author addresses the question of relevance or political commitment and it is in this capacity that he incorporates into his methodology analyses and references to gender and queer studies, psychoanalysis, and postcolonial studies (20). The book has thus a clear political agenda and the author himself is as intellectually honest as to openly declare his critical apparatus,

Como todos los análisis de textos considerados "literarios", éste se encuentra condicionado, en varios sentidos, por el aparato crítico empleado. Frente a la opción de ocultar dicho aparato (lo que a veces se realiza con la solapada intención de ocultar la propia ideología) constituye una cuestión de honestidad intelectual con el lector explicitar las herramientas teórico-críticas puestas en juego para abordar el estudio de estas obras. (19)

\footnotetext{
${ }^{1}$ The author himself makes reference to this dearth of studies: "lo cierto es que, como ya tuvimos occasion de manifestar, no existen estudios comparados monográficos de cierto calado sobre el honor en los dramas de honor de Calderón y en Shakespeare" (286). He has rightfully commented on the same circumstance on page 9.
} 
His compromise with transparency leads him to declare later "que toda crítica es política, y que toda producción literaria es necesariamente ideológica" (291). He also enlarges on the exposition of his critical method in section 1.3, and further in sections 2.1 and 3.1., for cultural semiotics and cultural materialism respectively. It is clear then that his research is soundly grounded on rigorous and openly displayed ideological and critical positions. However, the author is not dogmatic, for on page 21, he states that far from trying to impose his approach as the only possible interpretation, he is rather attempting to increase the richness of the perception of the plays.

Of all the lines followed in his critical method, Lotman's cultural semiotics is the most original. It is also the least politicised part and the one that renders the clearest and most useful results. Situating honour, as a common unifying factor of the four plays, in the passage from symbolic to syntagmatic dominant cultural codes (Lotman), he points to the resulting effect that the prevailing degree of anxiety had on the perception and experiencing of this social apparatus, as regards any form of recognition of the value of the subject and as a means to guarantee his/her social integration. Thus, the man of honour in the four plays analysed finds himself departing from the medieval modelization of the ideal of attaining virtue through one's own means in what basically is an essentialist, paradigmatic system of symbolic interaction with a supernatural order (symbolic code). $\mathrm{He}$ is in the process of passing to the modelization of the modern period, which implies a relational, sintagmatic system of material interaction in the society on this Earth (syntagmatic code) under the pressure of opinion. It is within this general framework that the conflict of honour (and the precarious situation of wives) must be understood in the plays. Hence, similar social forces and pressures may be exposed as underlying and shaping the response to the demands of honour of deceptively autonomous subjects as different as Othello and Gutierre Alfonso, Lope de Almeida, or Juan Roca. To this is added the particular situation of Othello as Other and the anxiety caused by the need of self-fashioning and the fashioning by others in a context of raci(ali)sm as well as the hazardous situation of women in the four plays, whose voice is silenced and who are inscribed (i.e., written and read as texts) by men, and deprived of a discourse of their own. With all these accretions, the author fulfils the political programme 
inherent in his new historicist-cultural materialist approach: to analyse power relationships as a privileged ground to interpret texts, to disclose the operations of ideology in the mobilization of structures of meaning to legitimate hegemonic interests, and to determine to what extent there is proof of subversion versus containment in the dramatic texts $(95,279-280,82$ n.41).

Equally interesting and convincing is the author's argument for the moral assessment of the plays. He devotes to this issue a whole subsection ("Crítica del asesinato por honor" 3.4) and picks it up again in the general conclusions (294). In agreement with latest developments in criticism, he argues for a subversive interpretation of Calderonian (and Shakespearean) wife-murder dramas in which the tyrannical code of honour is made responsible for the ensuing unjust uxoricides. But different from many of these approaches, which might be termed as humanist, the author is interested not in pointing out the tragical consequences or the moral responsibility of the characters as individuals, but in highlighting the apparatus of honour as the immediate social causes operating behind the illusion of the autonomous subject. For, consequent with his materialist conception, Dr López-Peláez does not believe in the subject as something unified and continuous, but rather as a succession of artificial positions constructed by the pressure of social forces operating behind and alien to him/her. That is possibly why he willingly lets pass the opportunity to link his conclusions in this respect with the lately well-established trend to consider Calderonian wife-murder plays as instances of a native Spanish tragedy (see the critics I have mentioned above) and thus to touch upon the more general question of dramatic genres. This impression of mine is backed up by the fact that he openly declares his preference for Brechtian epic theatre over Aristotelian theatre, i.e., tragedy (274) for the well-known reasons of promoting or exposing alienation respectively.

The content of the book is arranged in three major chapters and proceeds orderly from a sound revision of the meaning and origins of the concept of honour (first chapter) to its conclusion through both a consideration of the dramatization (ch. II) and of the function 
(ch. III) of this code in Othello and in the Calderonian "dramas de honor."

The first chapter supplies us with a neat and comprehensive review of the concept of honour through history, something which is both a very convenient (in both senses of the word) resource for anybody venturing into this complex matter and a very stimulating starting point for serious discussion of the topic. It includes crucial issues such as the social implications of honour, its multidimensional character, its factorization, its historical evolution, and its literary embodiment.

Chapter II is to my mind the weakest part of the whole work. Its function is to present the ways in which honour is dramatized in the four plays under consideration. One would expect a survey of the ways in which the apparatus of honour is presented, enacted or ostended throughout on the stage. But the author does not always accomplish this programme. Instead, he starts with a long dissertation on cultural semiotics, which is interesting and clarifying enough but not appropriate for this section. Furthermore, his discussion of the concepts of the semiotics of drama and theatre is too long for the use that it is going to be put to later. Then he goes on to deal with another theoretical session on metadramatization, and then proceeds to discuss the dramatic function of several signs (handkerchief, dagger, water and fire, etc.). My objection here is twofold: on the one hand, most of the chapter seems to be more an excursion into the semiotics of drama and theatre or plot construction and bears little relation to the main topic of honour; on the other hand, almost all the sections of the chapter are presided over by, what I believe to be, instances of overinterpretation. I mean overinterpretation as an excessive opening of the semantic scope of the term for metadramatization, which allows one to put in the same box a wide range of dramatic techniques such as eaves-dropping, overhearing or confusion of identities with the ultimate end of relating them as part of the same phenomenon and then justifying uniformity of dramatic methods in the four plays analysed; and I would also say that there is overinterpretation in some of the symbolic analyses of the objects proposed, which, given their

\footnotetext{
${ }^{2}$ Honour is defined by the author, in rather Foucaltian terms, as a código or code, i.e., an articulated set of ideas, "a social apparatus with its own internal regulation ("un dispositivo social con una regulación interna propia," 24).
} 
semantic openness, may justify almost any interpretation. ${ }^{3}$ Nevertheless, section 2.4 ("Exceso and defecto de honor") aptly steers the discussion back to its appropriate course and meets the expectations promised by the title of the chapter.

Section III explores the function of honour in the four dramas under study. It starts again with a strong revision of the critical methods of the book, reinforcing the author's choices and insisting on the incorporation of all kinds of approaches contributing to the uncovering of the ideological mechanisms plus, I may imagine (for he invokes Jameson and his political unconscious), those interpretative practices that guide our unconscious habits of reading imposed by hegemonic forces. In this spirit, he resorts in varying degree to doses of psychoanalysis, feminism, post-colonial studies and gay studies and, though the book indeed reveals several illuminating ways of looking at the dramas and unearthing ways of subversion, it is at the cost of sometimes becoming far-fetched in handling the elusive semiosis of psychoanalysis even if it is put to the effect of counteracting hegemonic social forces. But I must confess that I am generally sceptical about the hermeneutic value of these methods, even as tools for cultural materialism and thus will leave the appreciation of these resources to readers more bent on these critical disciplines.

The conclusion or rather "conclusiones" pick up and summarize all the inferences made in the preceding chapters. They are pertinent and contribute many valuable starting points to the current state of the art mainly from the perspective of new historicism-cultural materialism and the semiotics of culture. In this, and not only in being the first extensive contrastive study on honour, this book also shows its pioneering nature. If anything, the conclusions suffer a little from the incorporation of disparate elements which, though currently admitted by the Neo-Marxist methods called in, here show some degree of discontinuity and lack of cohesion. Some of them are too subservient to the current paradigm of the humanities and give the impression of paying lip service to current trends in postmodernism, rather than being an integral part of the critical

\footnotetext{
${ }^{3}$ Take, for instance, the case posed by Linda Boose (131), and carried forward by the author. Here, symbolic meanings are strainedly added to the sign handkerchief parasiting on the patent and arguable dramatic function of this theatrical item, i.e., its character as necessary ocular proof for the unfolding of the plot.
} 
apparatus. However, as I have already said, the book fully accomplishes its goal and will really be a major discovery for those scholars engaged in integrating both interpretation and praxis as part of the same dialectical process.

\section{References}

Caro Baroja, Julio 1968. “Honor y vergüenza. Examen histórico de varios conflictos." Ed. J. G. Peristiany El concepto del honor en la sociedad mediterránea. Barcelona: Labor: 77-127.

Castro, Américo 1916. "Algunas observaciones acerca del concepto del honor en los ss. XVI y XVII." Revista de Filología Española 3: 1-50.

Correa, Gustavo 1958. "El doble aspecto de la honra en el teatro del siglo XVII." Hispanic Review 26: 99-107.

Cruickshank, D. W. 1973. "'Pongo mi mano en sangre bañada a la puerta'. Adultery in El médico de su honra." Ed. R. O. Jones. Studies in Spanish Literature of the Golden Age presented to Edward M. Wilson. London: Tamesis Books: 45-62

Dañobeitia Fernández, Mª Luisa 1992. "The Inevitable Death of Desdemona: Shakespeare and the Mediterranean Tradition." Ed. Santiago González Fernández-Corugedo. Proceedings of the II Conference of the Spanish Society for English Renaissance Studies. Oviedo: Universidad de Oviedo: 83-95.

Gutiérrez Nieto, Juan Ignacio 1981. "Honra y utilidad social. En torno a los conceptos de honor y honra." Ed. Luciano García Lorenzo. Calderón: Actas Congreso Internacional: 881-895.

Jones, Cyril A. 1965. "Spanish Honour as Historical Phenomenon, Convention and Artistic Motive." Hispanic Review 33: 32-39.

López-Peláez Casellas, Jesús 1995. "Estudio comparado de Othello, de William Shakespeare y los "dramas de honor" de Pedro Calderón." Ph. Dissertation. Microfiche edition. Granada: Universidad de Granada.

López-Peláez Casellas, Jesús 1998. “'Ocular Proofs': Análisis comparado de los formantes 'pañuelo' y 'daga' en Othello y EI médico de su honra." Studia Neophilologica 70: 187-196.

López-Peláez Casellas, Jesús 2004a. "A Brechtian Approach to Shakespeare and Calderon." Cuadernos de ALDEEU: 35-49.

López-Peláez Casellas, Jesús 2004b. "Review of Ewan Fernie 2002: Shame in Shakespeare." Atlantis 26/2: 139-144.

Maravall, José Antonio 1975. La cultura del barroco. Barcelona: Ariel.

Maravall, José Antonio 1979. Poder, honor y élites en el siglo XVII. Madrid: Siglo Veintiuno. 
Reviews

Menéndez Pidal, Ramón 1940. "Del honor en el teatro español." De Cervantes y Lope de Vega. Madrid: Espasa-Calpe: 145-173.

Mintz, Jacqueline Ann 1982. "A Comparative Study of Shame in Spanish and English Renaissance Drama." Ph. Dissertation. Berkeley: University of California.

Oostendorp, H. Thomas 1969. "El sentido del tema de la honra matrimonial en las tragedias de honor." Neophilologus 53: 14-29.

Parker, A. A. 1975. "El médico de su honra as tragedy. " Hispanofila 2: 3-23 (Special issue on the Spanish comedia).

Parker, A. A. 1976 (1962). "Hacia una definición de la tragedia calderoniana." Eds. Manuel Durán, Roberto González Echevarría. Calderón y la crítica: historia y antología, Madrid: Gredos, tomo I: 359-387.

Regalado, Antonio 1995. Calderón. Los orígenes de la modernidad en la España del Siglo de Oro. Barcelona: Destino. 2 vols.

Ricart, Domingo 1965. "El concepto de la honra en el teatro del siglo de oro y las ideas de Juan de Valdés." Segismundo 1: 43-64.

Romero Cambra, Pedro Javier 2007. "Massinger and Carranza: A Note on Fencing and Points of Honour in Sixteenth- and Seventeenth-Century Drama." Notes and Queries 54/4: 392.

Ruiz Ramón, Francisco 200o. Calderón, nuestro contemporáneo. Madrid: Castalia.

Ruiz Silva, J. C. y L. Alvarado 1979. “Calderón-Shakespeare: sobre el honor y los celos." Arbor 386: 175-191.

Viel-Castel, Louis de Fevrier 1841. "Le thêatre espagnol. De 1'honneur comme ressort dramatique dans les pièces de Calderon, Rojas, etc." Revue de deux mondes: 397-421.

Wardropper, Bruce W. 1976. "Poesía y drama en El médico de su honra de Calderón." Calderón y la crítica: historia y antología. Madrid: Gredos: 582597 .

Wardropper, Bruce W. 1981. "The Wife-Murder Plays in Retrospect". Revista Canadiense de Estudios Hispánicos 5/3: 385-395.

Wilson, Edward M. 1980. Spanish and English Literature of the 16th and 17th Centuries. Cambridge: Cambridge University Press.

How to cite this review:

García García, Luciano. Review Jesús López-Peláez Casellas. 2009. “Honourable Murderers" El concepto del honor en Othello de Shakespeare y en los dramas de honor de Calderón. Bern-Oxford: Peter Lang. SEDERI 20 (2010): 165-172.

Author's contact: lugarcia@ujaen.es 


\title{
Glyn Redworth. 2008 \\ The She-Apostle. \\ The Extraordinary Life and Death of Luisa de Carvajal Oxford: Oxford University Press
}

\author{
Felipe Fernandez-Armesto \\ Tufts University
}

The more we learn about the devotion and endurance of Catholicism in early modern England, Scotland, Wales and the Protestant-ruled parts of the Netherlands, the stranger it seems that Catholics were never able to assert themselves politically in a sustained fashion, or influence mainstream culture profoundly or, in the long run, maintain their strength in numbers. The story is in some respects one of a slow withering of identity and waning of collective memory, but in the cities effective state repression seems to have been decisive. One of the most impassioned voices to express frustration in the face of persecution in early seventeenth-century London was that of Luisa de Carvajal. Orphaned in childhood and subjected, in her guardian's house, to discipline abusive even by the standards of her day, she rejected marriage but had no more vocation for the life of a conventional nun than of a conventional wife. At the age of nearly forty she abjured an aristocratic inheritance in Spain to become the first independent female missionary, dedicating her life to the attempted re-evangelisation of a country she did not know, and whose language she could not speak.

In broad outline the story Glyn Redworth tells of her is familiar. Elizabeth Rhodes wrote a good biography a few years ago (2000). Redworth has not found any significant new sources and properly keeps his predecessor's work in view, sometimes making his challenges implicit. He takes us deeper into the problems, however, than ever before and provides a more satisfying account, partly because of his faithful knowledge of the backgrounds in English, Spanish and religious history (though there is scope to dissent from 
his assumption that Spanish policy towards England changed with Philip II's death (178) and his assertion that Morisco "expulsees" from Spain amounted to "a third of a million" (186)), and partly because of his deft readings of the evidence, which are always alert to the subtle linguistic nuances, pertinent rhetorical conventions and cunningly concealed agendas.

Luisa emerges as a vital, paradoxical person. She disputed with fishwives in Cheapside about Christ and advised princes and kings about marriages, diplomatic appointments, peace and war. She deftly manipulated men, but always seemed to defer to male authority. She evinced infinite charity to the victims of Protestant intolerance but cheerfully urged on the martyrdom of the Moriscos. She inspired love in spite of herself. She was always a source of "headache" (175) to Ambassador Don Pedro de Zúñiga, but he never lost patience with her. His successor treated her with froideur yet begged for her help. She was always a focus of conflict for her companions in religion, who were often the object of her barbed critiques, but they never abandoned her. She was a ferocious networker, shameless and successful in soliciting funds for her mission; and she embraced poverty with utter sincerity. She was no feminist avant la lettre but her sense of mission transcended conventional notions of gender. Redworth's reading of her rule for her companions in religion makes Luisa "a female Jesuit" (155), who intended to create a female equivalent of the Company, with religious women who would sally from their convent to contend against heresy in the streets.

She made converts. The most poignant story is of her carpenter, Richard Brough, a bible-thumping Protestant, whom she engaged in disputation and who found her final sufferings and death so inspiring that he ended up as the resident factotum of the English College of Valladolid. Her greatest achievements, however, were twofold: first, as an example of steadfastness and source of comfort to the existing Catholic community in London, and especially to their martyrs; and secondly as a ghoulish Pimpernel -a rescuer of relics. Redworth describes rivetingly her midnight grave-grubbing for the quartered limbs of martyred Catholics, which the authorities buried extra-deep and mixed with the remains of criminals to deter relic-hunters, before Luisa lovingly recovered the grisly, holy specimens and dried them out for secret export to the continent. 
Ironically, possession of her own remains was so fiercely contested that it remains unresolved, frustrating the establishment of a cult and impeding the canonisation Luisa seems to have deserved.

Of the problems Redworth leaves unsolved, the first is that of why Luisa undertook such an unprecedented and unpromising enterprise in the first place. She knew England by repute long before visiting it, having lived next door to the English College in Valladolid. She felt drawn by stories of English martyrs, and resolved on her mission even before giving her inheritance away to the Jesuits. She always insisted that she went to England "to seek martyrdom" (61). Strictly speaking, however, true martyrdom is always unsought and Luisa was too well educated and too interested in theology to suppose otherwise. She must have known, moreover, that England would never dare execute a Spaniard of such impeccable social connections as herself, even under the considerable provocation she rather ostentatiously gave. Probably, though she expressed pious envy of English friends who died for their faith, what she really wanted was sanctification through suffering.

In some ways, her hopes were long frustrated. Redworth argues convincingly that the English authorities deferred her imprisonment because they were unwilling to acknowledge menace in someone of her sex. But even before she gleefully embraced two brief spells in prison she endured so many trials of poverty, indignity, broken health, physical pain, danger, stress and stifled hopes that England can be said to have justified itself as a choice of place of mortification. Most commentators piously classified her death as martyrdom because, although the enemy did not inflict it, they precipitated it by using her so ill.

Despite painstaking efforts and strenuous speculations, Redworth can cast no light on why the powers-that-be in the Catholic world supported Luisa in a course they might have deemed unwomanly or unwise. It is tempting to appeal to her character -her powers of persuasion, her evidence of vocation (manifest, not least, in her ability to master English eventually) and the defiant habits that helped keep her out of gaol for so long. Even harder to understand is why she was allowed to stay in England after her first arrest, with its adverse resonances in international politics. Perhaps, as Redworth suggests (177), Archbishop Ribera wanted her prayers - 
or perhaps he wanted a martyr to hallow his policy of war $\grave{a}$ l'outrance against the heretics. Finally, the problems of exactly who formed her permanent household and religious community in London, and how deeply and extensively she helped to connect London's Catholics, continue to defy exact solutions.

Redworth, as always, writes well, at a brisk, engaging pace, which the short chapters help sustain. Flashes of donnish humour enliven the pages. On page 194, in my favourite passage, the author describes Luisa's prostration before two Catholic martyrs, and how she kissed "their lucky feet," before adding, "She also sent [...] pear tartlets." There are some editorial lapses. Luisa's companion, Inés de la Encarnación, is introduced before we are told who she is; and there are distressing signs that misleading grammar-checking software has been used.

\section{References}

Elizabeth Rhodes 2000. This Tight Embrace: Luisa de Carvajal y Mendoza (15661614). Milwaukee Wisc.: Marquette University Press.

How to cite this review:

Fernandez Armesto, Felipe. Review of Glyn Redworth. 2008. The She-Apostle. The Extraordinary Life and Death of Luisa de Carvajal. Oxford: Oxford University Press. SEDERI 20 (2010): 173-176.

Author's contact: Felipe.Fernandez-Armesto@nd.edu 


\title{
Joseph P. Ward ed. 2008 \\ Violence, Politics, and Gender in Early Modern \\ England \\ New York: Palgrave MacMillan
}

\author{
Carme Font Paz \\ Universitat Autònoma de Barcelona
}

The crossroads between early modern cultural studies and women's writing has paved a fertile ground for a keener appreciation of the early modern period. Since in the 1980s Joan Kelly posed the question "Did women have a Renaissance?" (1984:19-50 $)^{1}$ a number of significant questions have been tackled regarding women's participation in the literary culture of the sixteenth and seventeenth centuries in England. First among these concerns was the extent to which women benefited themselves from the winds of political, religious and social changes that blew in the seventeenth century and, very especially, in the Restoration period. The main contribution of historians such as Joan Kelly herself, Mary Prior (1985), Sara Mendelson (1987), Patricia Crawford (Mendelson \& Crawford (1998) or Moira Ferguson (1985) was to trigger an academic interest in pre-nineteenth century women's lives which began to gravitate from a purely historical perspective towards a cultural and, then, a literary one, thus creating a sizeable community of scholars devoted to enlightening the textual production of English women in early modernity.

The work of editor, author and archivist Betty S. Travitsky represented a turning point in the study of sources from that period by inaugurating a prolific trend of compilations of early modern texts by women. Travitsky's The Paradise of Women: Writings by

\footnotetext{
${ }^{1}$ Kelly challenged the excessively literary readings of early modern women's writing, inviting us to explore non-canonical and "para literary" texts by women authors.
} 
Englishwomen of the Renaissance (1980) not only offered a wide and curious variety of literary pieces (from poems to journals and political pamphlets), but she quite literally paraded the sheer diversity of texts awaiting to be examined with a critical eye: the documents assembled formed an anthology of poorly studied items awaiting to be assessed by present-day scholars. From then on, several anthologies of women's writings in the early modern period have followed, usually including facsimiles, transcriptions, or editions; a number of these anthologies involve an edition of the text, some of the most representative being Elaine Hobby's Virtue of Necessity: English Women Writing (1990); Anita Pacheco's Early Women Writers 1600-1720 (1997) and A Companion to Early Modern Women's Writing (2002); Betty Travitsky's Female and Male Voices in Early Modern England: An Anthology of Renaissance Writing (2000); and more recently, Helen Ostovich's Reading Early Modern Women (2004). All of these contributions share a willingness to map out the genres, topics, authors, characters and voices which formed the rich melting pot of writings by women from the late Elizabethan period till the early 1700 .

Several of such anthologies, together with their corresponding critical essays providing depth and scope to each department of women's writing, bring together a wide range of methodological and interdisciplinary frameworks from which to consider the connections between gender, writing and culture. Noteworthy examples of this include Clare Brant's and Diane Purkiss' (eds.), Women, Texts and Histories, 1575-1760 (1992); Isobel Grundy and Susan Wiseman (eds.), Women, Writing, History, 1640-1740 (1993), or Margaret P. Hannay (ed.), Silent but for the Word: Tudor Women as Patrons, Translators and Writers of Religious Works (1985). Whereas early critical works necessarily focus on introducing the texts and the authors, providing biographies and a historical background, these and other "second-generation" books on early modern women writers began to depart from the descriptive model to become actively involved in reinterpreting the early modern period in terms of a complete reading of its various voices. This entailed a change of direction as far as critical research and interpretation is concerned: women's voices were no longer seen as either subsumed by established canonical texts from the early modern period, or kept in isolation from the canon. These anthologies are usually divided into thematic areas, for instance, religious tracts, domestic manuals, 
political pamphlets or personal letters. The current scholarly trend is to zoom in and devote every anthology to a single topic, like religion, politics or domesticity, paying attention to the analysis and specificity of the texts within their particular cultural environment.

One of the most fruitful loci of thematic study has been the connection between politics, religion and gender. Susan Wiseman's Conspiracy and Virtue (2006), Megan Matchinske's Writing, Gender and State in Early Modern England (1998), Jennifer Richards' and Alison Thorne's (eds.) Rhetoric, Women and Politics in Early Modern England (2007), Katharine Gillespie's Domesticity and Dissent in the Seventeenth Century (2004) or Scott Paul Gordon's The Power of the Passive Self in English Literature, 1640-1770 (2002) offer fresh insight into the complex interactions of power and the subversive discourses employed by women in the early modern period to bear or bypass patriarchal authority in political, domestic and religious spheres.

Joseph P. Ward, Associate Professor and Chair of the Department of History at the University of Mississippi, inquires as well into the axis of gender and politics by paying special attention to the ways violence has meddled with these two. The essays in his collection Violence, Politics, and Gender in Early Modern England show that early modern claims of political authority were often expressed through violence: not only states and factions tested one another through warfare, but violence was also displayed in everyday encounters between those with and those without power. Besides, they share a broader historical milieu in which violence that either resulted from or expressed hostility toward the established gender system was a regular feature of political life. Through an analysis of a particular type of gendered violence, each of the essays delves into the nature of early modern authority. They focus on the experiences of the elite and the non-elite, of men and women, drawing upon canonical and non-canonical literary works as well as archival and manuscript sources.

Ward's purpose is to demonstrate the "tenuous nature of patriarchal authority in early modern England" (2). The word "tenuous" may strike the reader as an unfair adjective given the near unanimous scholarly consensus that early modern society exhibited a kind of patriarchy which was everything except tenuous or fragile. However, the solid arguments and documentary sources displayed in this collection make the convincing point that time and again, 
early modern men and women demonstrated their compliance with a system that distributed the right to violence unequally among the sexes, but time and again, too, they demonstrated their lack of confidence in that system. Each chapter seems to subtly challenge the historiographical notion that the early modern period was, by definition, harshly patriarchal by testing the extent to which violence supported gender norms and by exploring the uneven implementation of patriarchal theory in early modern England. This defiance to the concept of patriarchy as a monolithic state of affairs in which only women were to become its victims is threaded through two major premises or sections in the book: the first, entitled "Venerable Patriarchs/Vulnerable Patriarchs," addresses the instability of patriarchal power in the sixteenth and seventeenth centuries. Its four contributions (by Paul S. Seaver, Cristine M. Varholy, Celia R. Daileader and Katharine Gillespie) shed some sober light onto the fact that if men were the natural leaders of society, in practice their authority faced several limits. In this regard, Seaver's study of the Apprentice Riots prevalent in the late sixteenth and early seventeenth century London, as well as Daileader's analysis of subversive rhetorical strategies in Shakespeare's and Middleton's Lucrece poems, make the convincing point that violence against men and women was exerted equally, although the strategies they deployed against it might be different. The book's second section, "Gender and State Violence," delves into the exercise of male authority by focusing on the gendered implications of statesponsored discipline. Here, the essays by Muriel C. McClendon, Myron C. Noonkester, Shannon Miller, Melissa Mowry and Jennine Hurl-Eamon show that violence was a language states used to communicate their authority, so that in the diffuse power structure of early modern England, the right of men to use the so-called "appropriate" violence against women extended from the leaders of church and state all the way to the heads of individual households. The chapter by Muriel Noonkester illustrates wonderfully this point by exploring the dilemmas that early modern male magistrates faced when they tried to exercise violence without promoting it, while Shannon Miller's contribution reads Aphra Behn's Oroonoko against the intense violence directed towards the opponents of the Restoration Crown and, in particular, to the novel's African protagonist. 
Drawing on the sources and methods of literary criticism and social history, Ward's collection of essays shows how, in the words Frances Dolan uses in her Afterword, "different forms of violence meant different things at different moments for different people" (249). They take a generally supportive view of Lawrence Stone's argument that violence, or the threat it posed to individuals, helped to shape a myriad of social relations in the early modern period that may not always transpire in archival records (Stone 1983). And when read as a whole, Ward's Violence, Politics and Gender in Early Modern England invites us to reconsider the ways in which violence expressed the politics of gender in early modern England.

\section{References}

Brant, Clare and Diane Purkiss eds. 1992. Women, Texts and Histories, 15751760. London: Routledge.

Ferguson, Moira 1985. The First Feminists. Indiana: Indiana University Press.

Gordon, Scott Paul 2002. Power of the Passive Self in English Literature, 16401770. Cambridge: Cambridge University Press.

Grundy, Isobel and Susan Wiseman, eds. 1993. Women, Writing, History, 1640-1740. London: Batsford.

Hannay, Margaret, ed. 1985. Silent but for the Word: Tudor Women as Patrons, Translators and Writers of Religious Works. Ohio: Kent State University Press.

Hill, Christopher 1991 (1972). The World Turned Upside Down. London: Penguin Books.

Kelly, Joan 1984. Women, History and Theory: The Essays of Joan Kelly. Chicago: University of Chicago Press.

Matchinske, Megan 1998. Writing, Gender and State in Early Modern England. Cambridge: Cambridge University Press.

Mendelson, Sara 1987. The Mental World of Stuart Women. Brighton: University of Massachusetts Press.

Mendelson, Sara and Patricia Crawford 1998. Women in Early Modern England. London: Oxford University Press.

Ostovich, Helen, ed. 2004. Reading Early Modern Women. New York: Routledge.

Prior, Mary 1985. Women in English Society 1500-1800. London: Routledge.

Richards, Jennifer and Alison Thorne eds. 2007. Rhetoric, Women and Politics in Early Modern England. London: Routledge. 
Reviews

Stone, Lawrence 1983. The Family, Sex and Marriage in England 1500-1800, New York: Harper.

Travitsky, Betty 1989. The Paradise of Women: Writings by Englishwomen of the Renaissance. New York: Columbia University Press.

Wiseman, Susan 2006. Conspiracy and Virtue. Oxford: Oxford University Press.

How to cite this review:

Font Paz, Carme. Review of Joseph P. Ward ed. 2008. Violence, Politics, and Gender in Early Modern England. New York: Palgrave MacMillan. SEDERI 20 (2010): 177182.

Author's contact: Carme.Font@uab.cat 